\title{
3. MINERALOGY AND TEXTURES OF IRON-TITANIUM OXIDE GABBROS AND ASSOCIATED OLIVINE GABBROS FROM HOLE 735B1
}

\author{
Kazuhito Ozawa, ${ }^{2}$ Peter S. Meyer, ${ }^{3}$ and Sherman H. Bloomer ${ }^{4}$
}

\begin{abstract}
Abundant iron-titanium (Fe-Ti) oxide gabbro, olivine gabbro, and troctolite were drilled at Hole 735B adjacent to the Atlantis II Fracture Zone of the Southwest Indian Ridge during Leg 118. The Fe-Ti oxide gabbro occurs as intrusive bodies into olivine gabbro with very sharp intrusive contacts. The size of the intrusive bodies varies from a millimeter to a few tens of meters. Mineralogical parameters, such as anorthite content of plagioclase and $\mathrm{Mg} /(\mathrm{Mg}+\mathrm{Fe})$ ratios of mafic minerals exhibit bimodal distributions corresponding to olivine and $\mathrm{Fe}-\mathrm{Ti}$ oxide gabbros, respectively. When the two major gabbro types are looked at separately, several downhole mineralogical cycles are recognized. The Fe-Ti oxide gabbros exhibit two such cycles with plagioclase becoming more sodic and mafic minerals becoming more iron-rich downward in the drill core. The olivine gabbros and troctolites, however, exhibit two cycles showing an upward increase in sodium in plagioclase and iron in mafic minerals. The mineralogical variations of these gabbros and the intrusive contact relationships probably resulted from downward intrusion of evolved magma into underlying solid or almost solidified olivine gabbros and troctolite. The dense evolved melt at the top of the cumulus pile probably formed from the crystallization of olivine gabbro cumulates followed by extreme fractional crystallization of residual melt in an isolated, ephemeral magma chamber. The interlayered occurrence of evolved and primitive gabbros from Hole 735B represents a typical section of lower ocean crust formed at a very slow spreading ridge.
\end{abstract}

\section{INTRODUCTION}

Basalts erupt on the seafloor after undergoing varying degrees of crystallization in magma chambers beneath midocean ridges. The crystallization products of mid-ocean ridge basalts (MORB) form gabbros that make up oceanic layer 3 . To date, most oceanic gabbros have been dredged from fracture zones and rift valley walls (Hodges and Papike, 1976; Miyashiro and Shido, 1980; Tiezzi and Scott, 1980; Hébert et al., 1983; Walker and DeLong, 1984; Batiza and Vanko, 1985; Elthon, 1987; Meyer et al., 1989). The fragmental nature of dredged samples, however, limits their usefulness for petrologic modeling of magmatic accretion at mid-ocean ridges. Drilling at Site 735 on Leg 118, however, succeeded in recovering an almost complete $500-\mathrm{m}$ section of gabbroic rocks that originally formed at the axis of the Southwest Indian Ridge. The core from Hole 735B provides the first view of lower oceanic-crust stratigraphy and offers an opportunity to study the remnants of a mid-ocean ridge magmatic system. These gabbroic rocks exhibit remarkable chemical variations and may represent accumulated crystals at various stages in the evolution of a mid-ocean ridge magma chamber.

This study reports petrographic and mineralogical characteristics of $\mathrm{Fe}-\mathrm{Ti}$ oxide gabbros that may be related to a localized occurrence of evolved magma beneath a slowspreading ridge. The Fe-Ti oxide gabbros are present throughout the whole sequence of the drilled section as intrusive bodies into olivine gabbros and rarely into troctolite. This mixed occurrence of evolved and primitive gabbros with a clear mineralogical gap may be representative of lower oce-

\footnotetext{
${ }^{1}$ Von Herzen, R. P., Robinson, P. T., et al., 1991. Proc. ODP, Sci. Results, 118: College Station, TX U.S.A. (Ocean Drilling Program).

${ }^{2}$ Geological Institute, Faculty of Science, University of Tokyo, Tokyo, 113, Japan.

${ }^{3}$ Woods Hole Oceanographic Institution, Woods Hole, MA 02543 , U.S.A.

${ }^{4}$ Department of Geology, 675 Commonwealth Ave., Boston University, Boston, MA 02215, U.S.A.
}

anic crust at slow spreading ridges particularly in the proximity of transform faults.

\section{Olivine-Bearing Gabbro, Olivine Gabbro, and Troctolite}

The petrography of olivine-bearing gabbro, olivine gabbro, and troctolite has been summarized by Bloomer et al. (this volume). Olivine-bearing and olivine gabbros are the most abundant rock types recovered from Hole 735B. They are the main rock types in lithologic Units II, V, and VI, and contain trace amounts of interstitial orthopyroxene and opaque minerals, which are commonly sulfide or ilmenite. Modal proportions of olivine, plagioclase, and clinopyroxene vary considerably, which reflects modal layering or irregular distribution of crystals in coarse-grained rocks. The troctolites from Hole 735B exhibit either medium-grained poikilitic or fine-grained equigranular textures. They contain trace amounts of spinel (up to $1 \%$ ) and sulfide, but no primary $\mathrm{Fe}$-Ti oxides have been observed. Troctolites or troctolitic gabbros are common in Unit VI and their frequency tends to increase toward the bottom of the hole. Some olivine gabbros contain clinopyroxene that is vermicularly intergrown with orthopyroxene + pale brown amphibole. Such olivine gabbros tend to be more primitive than those without clinopyroxene free of the vermicular intergrowth (Fig. 1).

\section{Iron-Titanium Oxide Gabbro}

Iron-titanium (Fe-Ti) oxide gabbros generally contain greater than $2 \%$ (rarely less than $1 \%$ ) Fe-Ti oxides (ilmenite and magnetite). In addition to $\mathrm{Fe}-\mathrm{Ti}$ oxides, these gabbros contain clinopyroxene with $\mathrm{Mg} \# \mathrm{~s}(100 \times \mathrm{Mg} /(\mathrm{Mg}+\mathrm{Fe}))<75$, plagioclase with An contents $<50$, \pm olivine $(\mathrm{Mg \# s}<65)$, \pm orthopyroxene, and \pm inverted pigeonite. Accessory primary phases include common brown hornblende and rare apatite and zircon.

Most of these Fe-Ti oxide gabbros have been metamorphosed and contain green hornblende, actinolite, epidote, albite, chlorite, and sphene as metamorphic minerals. They 
A

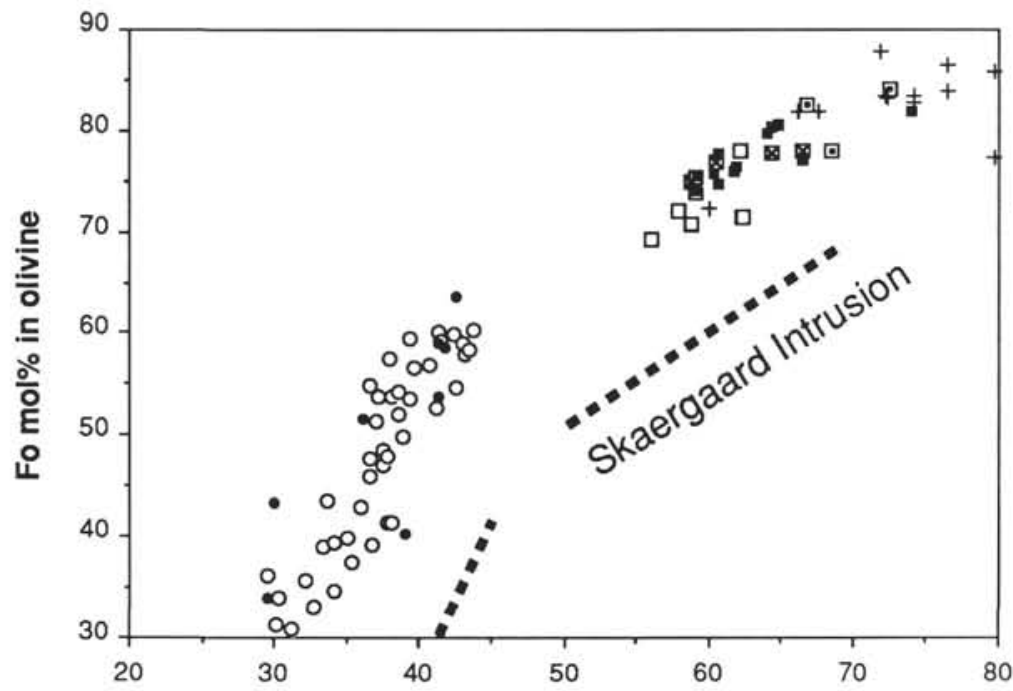

B

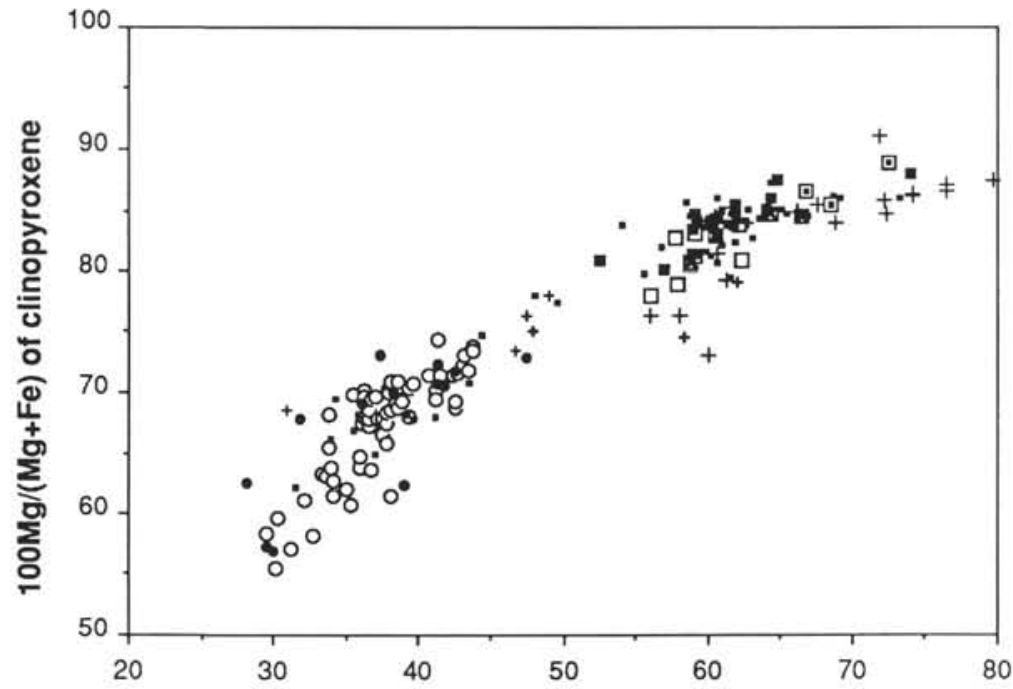

C

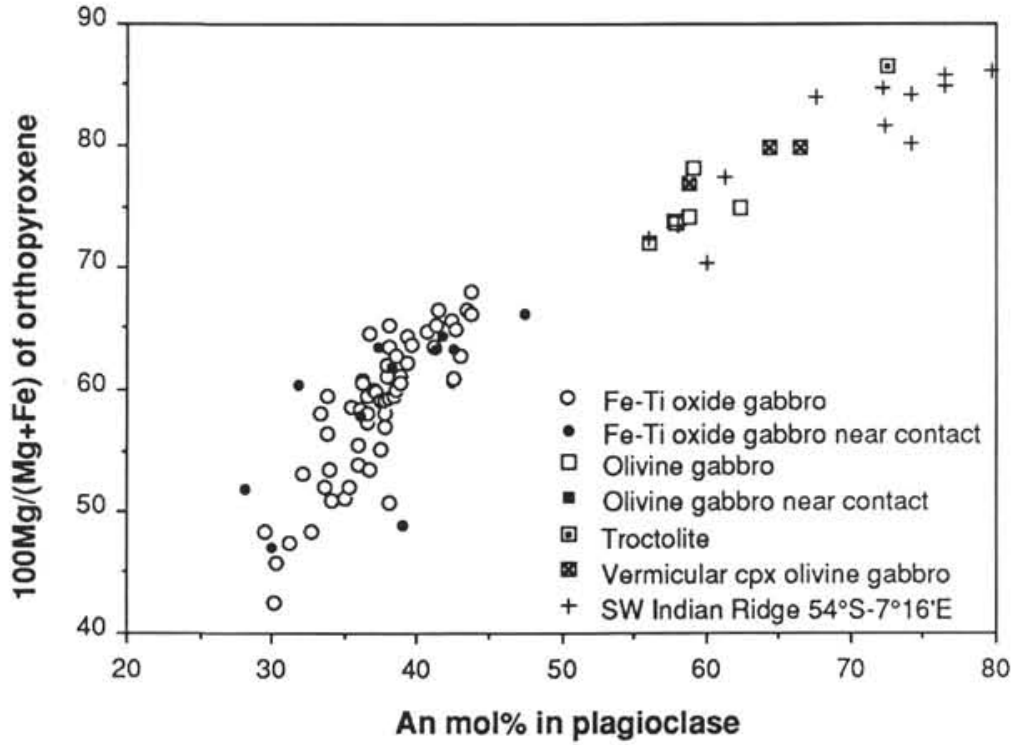

Figure 1. Average An content in plagioclase vs. average $\mathrm{Mg} /(\mathrm{Mg}+\mathrm{Fe})$ ratios of mafic minerals (A, Olivine. B, Clinopyroxene. C, Orthopyroxene) in gabbros from Hole 735B. Solid small symbols imply the gabbros in contact with each other in thin sections. Those data for olivine gabbro were obtained from cores $1-3 \mathrm{~cm}$ away from the contact. Small solid squares and small pluses are the data obtained by P. S. Meyer at MIT (Bloomer et al., this volume) and those for deformed and metamorphosed samples in Unit 1, respectively. Data for Southwest Indian Ridge are taken from Meyer et al. (1989) and those for Skaergaard Intrusion are from Wager and Brown (1967). 
Table 1. Petrographic table of the studied Fe-Ti oxide gabbros from Hole 735B.

\begin{tabular}{|c|c|c|c|c|c|c|c|c|c|c|}
\hline $\begin{array}{l}\text { Core, section, interval } \\
(\mathrm{cm})\end{array}$ & $\begin{array}{l}\text { Depth } \\
\text { (mbsf) }\end{array}$ & $\begin{array}{l}\text { Opaque } \\
(\%)\end{array}$ & $\begin{array}{c}\text { Olivine } \\
(\%)\end{array}$ & $\begin{array}{l}\text { Opx }+ \text { pig } \\
(\%)\end{array}$ & Ca-poor px & Metamorphism & Deformation & Foliation/layer & $\begin{array}{c}\text { Grain } \\
\text { size }\end{array}$ & Rock type \\
\hline \multicolumn{11}{|l|}{$118-735 \mathrm{~B}-$} \\
\hline 12R-1, 45-47 & 39.92 & $<2$ & $0 ?$ & $10-5$ & Opx + pig? & Extensive & Porphy & Def? & 5.0 & Gabbronorite \\
\hline 14R-1. 93-97 & 51.98 & $<2$ & tr./alt. & $<1$ & Opx & Minor & Mylonitic & & 7.0 & Inst ol gabbro? \\
\hline $19 \mathrm{R}-5,47-50$ & 83.02 & tr. & 0 & $10-15$ & Opx & Mod & Porphy & & 4.0 & Gabbronorite \\
\hline $19 \mathrm{R}-5,55-60$ & 83.12 & $<1$ & 0 & 5 & Opx & Weak & Porphy & & 6.0 & Gabbronorite \\
\hline $20 R-1.111-114$ & 85.89 & $<1$ & $70-80$ & 2 & Opx+pig & Weak-mod & Porphy & & 4.0 & PI wehrlite \\
\hline $21 \mathrm{R}-1-2.82-89$ FETI & 90.47 & $5-10$ & 2 & 1 & Opx (pig?) & Extensive & Weak porphy & ? sz-mod lay & 7.0 & Inst ol gabbro \\
\hline $21 \mathrm{R}-2.27-32$ & 91.06 & 5 & 0 & 2 & Opx + pig & Weak-mod & Weak local pph & + & 18.0 & Pig gabbro \\
\hline $23 R-3.33-37$ & 102.61 & 20 & 0 ? & $3-5$ & Opx + pig & Weak-mod & Weak & & 9.0 & Pig gabbro \\
\hline $23 \mathrm{R}-3,34-37$ & 102.61 & $5-7$ & 0 & $5-10$ & Opx + pig & Weak & Weak & & 15.0 & Pig gabbro \\
\hline $24 \mathrm{R}-2.95-97$ & 107.94 & $8-10$ & 0 & $2-5$ & Opx & Mod-ext & Weak-mod & & 4.0 & Gabbronorite \\
\hline $24 \mathrm{R}-2,120-126$ & 108.20 & $10-20$ & 0 & $10-20$ & Pig & Mod & Weak & & 7.0 & Pig gabbro \\
\hline 28R-1. $109-114$ & 127.47 & $<5$ & 0 & $2-3$ & Pig + opx & Weak-mod & Mod-porphy & & 4.0 & Pig gabbro \\
\hline $28 R-3,72-77$ & 129.54 & $5-10$ & 0 ? & $3-5$ & Pig & Weak-mod & Mod & & 30.0 & Pig gabbro \\
\hline $34 \mathrm{R}-4,8-12$ & 163.23 & 20 & 2.5 & 1 & Opx + pig & Weak & Weak & & 15.0 & Inst ol $\mathrm{gb}+\mathrm{r}$ \\
\hline $36 R-4,5-9$ & 174.80 & $<1$ & $5-10$ & $1-2$ & Opx & Weak-mod & Mod-porphy & + siz lay & 2.0 & Diss ox ol gb \\
\hline 37R-3-2.71-76 FETI & 180.13 & 1 & $1-3$ & $<1$ & Opx+pig ? & Minor & Weak & + & 0.5 & Diss ox ol gb \\
\hline $37 R-3.76-79$ & 180.18 & $1-3$ & 5 & 1.5 & Opx + pig & Mod & Weak & + siz lay & 1.0 & OI pig gabbro \\
\hline $37 R-3.80-82$ & 180.23 & $2-3$ & $2-3$ & $1-3$ & Pig & Weak-mod & Weak & + & 2.5 & Ol pig gabbro \\
\hline $38 \mathrm{R}-3,85-88$ & 184.25 & 5 & $1-2 ?$ alt. & 10 & Pig & Weak-mod & Mod & & 20.0 & Ol pig gabbro \\
\hline $38 \mathrm{R}-4 \cdot 24-28$ & 184.88 & $2-3$ & $2-3$ & $5-10$ & Pig + opx & Weak & Weak & $++\bmod$ lay & 4.0 & Ol pig gabbro \\
\hline $40 \mathrm{R}-5,0-4$ & 195.45 & $3-5$ & 5 & 10 & Opx & Minor & Minor-no & Weak & 7.0 & Ol gabbronort \\
\hline $40 R-5,4-8$ & 195.49 & 2 & 10 & $2-3$ & Opx & Minor & Minor-no & + siz-mod lay & 1.0 & Diss ox ol gb \\
\hline $43 R-3,95-102$ & 209.45 & $1-10 / 10 c z$ & 5 & $1-5$ & Opx & Minor & Very Minor & + siz-mod lay & 4.0 & Ol gabbronort \\
\hline $43 R-4.64-66$ & 210.23 & $1-2 /$ locz & 3 & 1 & Opx & No & No & $++\bmod l a y$ & 3.0 & Diss ox ol gb \\
\hline $44 R-2,16-24$ & 212.37 & 10 & 0 & 10 & Opx+pig & Weak & Weak & $+?$ & 10.0 & Pig gabbro \\
\hline $45 \mathrm{R}-1,5-12$ & 216.07 & $1-5 / \operatorname{loc} z$ & $1-5$ & $10-20$ & Opx + pig(locz) & Mod & Very minor & + siz-mod lay & 3.0 & OI pig gabbro \\
\hline $46 \mathrm{R}-1,48-58$ FETI & 221.47 & 1 & 5 & $<1$ & Opx & Minor & No & ++ & 3.5 & Diss ox ol gb? \\
\hline $46 \mathrm{R}-3,121-128$ & 224.68 & $4 / \operatorname{loc} z$ & 5 & $<1$ & Opx & Weak & No & + siz-mod lay & 0.8 & Diss ox ol gb \\
\hline $46 R-4,109-113$ & 225.83 & 10 & 0 & 1 & Opx (pig?) & Weak & Weak & & 20.0 & Pig gabbro \\
\hline $47 R-2,117-127$ & 228.52 & 10 & 1 & $<1$ & Opx & Weak & Very minor & & 15.0 & Inst ol gabbro \\
\hline $47 R-3.56-61$ & 229.26 & 15 & $1-2$ & 1 & Opx + pig & Weak & Weak & Weak & 5.0 & Inst ol $\mathrm{gb}+\mathrm{r}$ \\
\hline 47R-3-2, 143-149 FETI & 230.10 & $10-20$ & 5 & $<1$ & Opx & Weak & Minor & + & 5.0 & Inst ol gabbro \\
\hline $48 R-2.56-65$ & 232.80 & 5 & $1-2$ & 2 & Pig & Weak-mod & Weak & + & 4.0 & Inst ol gabbro \\
\hline $48 \mathrm{R}-2,109-113$ & 233.28 & $3-5$ & 4 & $<1$ ? & $?$ & Minor & No & + siz-mod lay & 0.3 & Ol feti microgb \\
\hline $48 R-3,112-116$ & 234.53 & $5-10$ & $2-3$ & $1-2$ & Opx+pig & Weak-mod & Weak & + & 4.0 & Inst ol gabbro \\
\hline $48 R-4,82-84$ & 235.51 & 5 & $2-1$ & $1-2$ & Opx & Weak & Weak & + & 2.5 & Inst ol gabbro \\
\hline $49 \mathrm{R}-1,42-46$ & 236.34 & 15 & 2 & $<1$ & Opx + pig? & Minor & No & + & 2.5 & Inst ol gabbro \\
\hline $49 R-2,94-100$ & 237.21 & 10 & $2-3$ & $1-2$ & Opx + pig & Weak & Weak & ++ & 5.0 & Inst ol gb $+r$ \\
\hline S0R-2. $43-47$ & 239.34 & $10-20$ & $2-3$ & $1-2$ & Opx+pig & Weak & No & + & 4.0 & Inst ol gabbro \\
\hline $50 R-3,62-67$ & 240.82 & $10-15$ & 1 & $1-2$ & Opx+pig & Weak & Weak & + mod-siz lay? & 4.0 & Inst ol gabbro \\
\hline 5IR-1. 94-99 & 244.03 & $5-10$ & 1 & 2 & Opx + pig? & Weak-mod & Weak & + mod lay & 5.0 & Inst ol gabbro \\
\hline SIR-1. 99-103 & 244.09 & $5-15$ & $1-2$ & $2-3$ & Opx + pig & Weak & Weak & + mod-siz lay & 4.5 & Inst ol gabbro \\
\hline $52 \mathrm{R}-1,91-100$ & 248.93 & 5 & 2 & 1 & Opx & Weak-mod & Minor & + & 4.0 & Inst ol $\mathrm{gb}+\mathrm{r}$ \\
\hline $52 \mathrm{R}-3,121-123$ & 251.60 & 2 & $2-3$ & $<1$ & Opx & Mod & Weak-porphy & ++ & 2.0 & Inst ol gabbro \\
\hline $52 \mathrm{R}-4,88-94$ & 252.67 & 10 & l/alt. & $<1$ & Opx & Weak-mod & Weak-porphy & ++ & 4.0 & Inst ol gabbro \\
\hline $53 \mathrm{R}-1.47-54$ & 253.45 & 8 & 2 & $<<1$ & Opx(pig?) & Weak & Weak porphy & + & 1.0 & Inst ol gabbro \\
\hline $53 \mathrm{R}-1,123-127$ & 254.12 & $5-10$ & $1-2$ & $<1$ & Opx+pig? & Mod & Weak-mod & + siz-mod lay & 4.0 & Inst ol gabbro \\
\hline $53 R-2,31-39$ & 254.55 & $5-10$ & 1 & $<<1$ & Opx & Mod & Weak-mod & + siz mod lay & 3.0 & Inst ol gabbro \\
\hline $54 \mathrm{R}-1.131-136$ & 259.25 & 6 & 10 & $<1$ & Opx & Weak & Porphy & & 4.0 & Ol feti gabbro \\
\hline $54 \mathrm{R}-3,20-24$ & 260.84 & $5-10$ & 20 & 1 & Opx & Mod & Weak-mod pph & Def ? & 8.0 & Ol feti gabbro \\
\hline $54 \mathrm{R}-3,125-127$ & 261.81 & 10 & $15-20$ & i & Opx & Weak & Porphy & Def ? & 3.0 & Ol feti gabbro \\
\hline $54 \mathrm{R}-5,117-119$ & 264.39 & 7 & $2-3$ & $i$ & Opx & Weak & Mod-porphy & Def? & 7.5 & Inst ol gabbro \\
\hline $55 \mathrm{R}-2,10 \mathrm{I}-105$ & 267.50 & 13 & $1-2$ & i & Opx+pig & Weak & Mod-porphy & & 7.0 & Inst ol gabbro \\
\hline $55 \mathrm{R}-2,110-120$ & 267.62 & $10-15$ & $4-7$ & $<1$ & Opx & Mod & Mod & Weak & 9.0 & Ol feti gabbro \\
\hline $55 \mathrm{R}-3,83-86$ & 268.81 & 5 & 5 & $<1$ & Opx & Weak-mod & Porphy-myl & & 1.0 & Ol feti gabbro \\
\hline $56 \mathrm{R}-2,11-14$ & 271.52 & $5-10$ & 3 & $<<1$ & Opx & No & Mylonitic & & 2.0 & Ol feti gabbro \\
\hline $73 R-4-2.82-87$ FETI & 370.23 & $5-10$ & 0 & $2-3$ & Opx & Minor & Weak-mod pph & Def? & 2.0 & Gabbronorite \\
\hline 73R-5-2. 72-78 FETI & 371.58 & $5-10$ & 0 & $1-2$ & Opx & Minor & No & & 3.0 & Gabbronorite \\
\hline $74 \mathrm{R}-6,27-35$ & 382.13 & 5 & 0 & 10 & Opx & Minor & No & & 0.4 & Poik gabbnort \\
\hline $76 \mathrm{R}-1-2,63-70 \mathrm{FETI}$ & 394.69 & $5-10$ & $<1$ & $15-20$ & Opx & Minor & No & & 10.0 & Gabbronorite \\
\hline 76R-1. 70-73 FETI & 394.74 & 1 & 0 & 2 & Opx & Minor & No & & 8.0 & Gabbronorite \\
\hline 76R-1, 99-110 FET1 & 395.08 & 5 & 0 & $5-10$ & Opx & Minor & No & & 8.0 & Gabbronorite \\
\hline 76R-3-2, 35-41 FETI & 397.06 & 5 & $3-5$ & $5-10$ & Opx & Minor & No & ++ mod lay & 0.8 & Ol gabbronort \\
\hline $76 \mathrm{R}-4,12-19$ & 398.20 & 3 & $<1$ & 20 & Opx + pig & Minor & No & ++ siz-mod lay & 1.0 & Gabbronorite \\
\hline $77 R-2.5-8$ & 404.96 & $<1$ & $5-10$ & $?$ & ? & Weak & Weak-mod & Def? & 0.8 & Diss ox ol gb \\
\hline $77 R-2.101-107$ & 405.89 & 1 & $10-20$ & $4-8$ & Opx & Minor & Weak-mod pph & Weak & 7.5 & Ol gabbronort \\
\hline 79R-7-2, 2-9 FETI & 422.82 & 5 & $5-10$ & 5 & Opx & Minor & Porphy-myl & & 3.0 & Ol gabbronort \\
\hline $80 R-3,67-71$ & 427.35 & $5-10$ & $5-10$ & 1 & Opx+pig? & Weak & Porphy & & 6.0 & Ol feti gabbro \\
\hline $80 R-6,130-135$ & 431.98 & 5 & $10-20$ & 2 & Opx +pig & Weak & Porphy & & 9.0 & Ol feti gabbro \\
\hline $80 R-7,10-18$ & 432.23 & $<5$ & $3-5$ & $<1$ & Opx & Mod & Weak & Siz lay def? & 0.8 & Ol feti microgb \\
\hline $80 \mathrm{R}-7.23-25$ & 432.32 & 5 & 7 & $<1$ & Opx & Weak-mod & Weak & + & 0.5 & Of feti microgb \\
\hline $82 \mathrm{R}-3-2,0-5$ FETI & 445.72 & 10 & $0 ?$ & 10 & Opx & Mod & Weak-mod & + mod lay & 3.0 & Gabbronorite \\
\hline $86 \mathrm{R}-4,123-130$ & 486.60 & $5-10$ & $5-10$ & $<1$ & Opx & Mod & Porphy & & 6.5 & Ol feti gabbro \\
\hline $86 R-6,143-145$ & 489.57 & 5 & 2 & 3 & Opx & Weak-mod & Porphy & & 3.0 & Inst ol gabbro \\
\hline
\end{tabular}

Note: Abbreviations are: loclz, localized; alt., altered; tr., trace; cpx, clinopyroxene; opx, orthopyroxene: pig, inverted pigeonite: mod, moderate: ext, extensive; porphy or pph, porphyroclastic: myl, mylonitic; def, deformation: siz, size; mod, modal; lay, layering: ol, olivine: opq. opaque mineral:,+ strong magmatic lamination;,++ very strong magmatic lamination: inst ol gabbro, interstitial olivine-bearing oxide gabbro; pl, plagioclase; inst ol gb $+r$, interstitial olvine-bearing oxide gabbro with corona structure; diss ox ol gb, disseminated Fe-Ti oxide olivine gabbro; ol feti microgb, olivine Fe-Ti oxide microgabbro; ol feti gabbro, olivine Fe-Ti oxide gabbro: poik gabbnort, poikilitic gabbronorite. Fe-Ti oxide gabbro in contact with olivine gabbro is indicated by "FETI" in the interval column. Grain size is representative one for clinopyroxene. 
commonly exhibit porphyroclastic or mylonitic textures with remarkable foliation and lineation, indicating that these gabbros were subjected to strong subsolidus deformation. Some specimens also exhibit a magmatic lamination which likely resulted from hypersolidus deformation of the cumulate pile (Dick et al., this volume). Magmatic lamination is always cut by deformation foliation, which can be clearly seen by the redistribution patterns of Fe-Ti oxides (Robinson, Von Herzen, et al., 1989). Magmatic lamination can be discriminated from deformation foliation by the absence of highly deformed plagioclase and olivine exhibiting strong wavy extinction, kink bands, or recrystallization. Magmatic lamination at levels shallower than $170 \mathrm{mbsf}$ is weak or absent, or possibly overprinted by deformation (Table 1; Fig. 7 in Robinson, Von Herzen, et al., 1989).

In spite of these secondary processes, primary magmatic structures, textures, and mineralogical characteristics are well preserved. Because this study focuses on igneous processes, only magmatic features are presented in the following petrographic descriptions. Some gabbros exhibit magmatic modal and/or size layering. They also commonly exhibit magmatic lamination defined by an elongate aggregate of $\mathrm{Fe}$-Ti oxides or preferred orientations of elongate plagioclase and clinopyroxene crystals. Fe-Ti oxide gabbros commonly occur as centimeter to meter scale veins and layers within the olivine gabbro. The boundaries between the Fe-Ti oxide gabbros and olivine gabbro are very sharp and are generally marked by the abrupt appearance of Fe-Ti oxides. This mixed occurrence of evolved and primitive gabbros over a $500-\mathrm{m}$ depth range is the most distinctive feature of the gabbros from Hole 735B. Some zones having thicknesses of more than a few meters also occur: these are located in the gabbronorite in the top $28 \mathrm{~m}$ of Unit $\mathrm{I}$ and in the 50-m-thick massive Fe-Ti oxide gabbro zone Unit IV. In the upper two thirds of Unit V, Fe-Ti oxide gabbro is almost absent (Fig. 2). In Unit IV, two zones of olivine gabbros having thicknesses of $50 \mathrm{~cm}$ and $1 \mathrm{~m}$ are present near the top of the massive Fe-Ti oxide gabbro. The proportion of Fe-Ti oxide gabbro increases downward from Units I to IV and from Units V to VI (Robinson, Von Herzen, et al., 1989). These two zones in the core are also marked by a downward increase in the abundance of Fe-Ti oxides and by downward trends to more evolved mineral compositions, e.g., lower An contents in plagioclase and lower $\mathrm{Mg \# s}$ in olivines and clinopyroxenes (Fig. 2 and 3 ).

Fe-Ti oxide gabbros can be divided into eight types according to modal proportions of primary phases and textural relationships (Table 1). These are gabbronorite, olivine gabbronorite, disseminated $\mathrm{Fe}-\mathrm{Ti}$ oxide olivine gabbro, olivine pigeonite gabbro, pigeonite gabbro, interstitial olivine-bearing $\mathrm{Fe}-\mathrm{Ti}$ oxide gabbro, olivine $\mathrm{Fe}-\mathrm{Ti}$ oxide gabbro, olivine $\mathrm{Fe}-\mathrm{Ti}$ oxide microgabbro.

\section{GEOLOGICAL SETTING OF HOLE 735B}

Hole 735B is located on a shallow platform in about $700 \mathrm{~m}$ of water on the east rim of the Atlantis II Fracture Zone, which is a $210-\mathrm{km}$ left lateral offset formed during ridge extension of the Southwest Indian Ridge at about $58 \mathrm{Ma}$ (Robinson, Von Herzen, et al., 1989). The platform is $9 \mathrm{~km}$ long in a north-south direction and $4 \mathrm{~km}$ wide, and is one of a series of uplifted blocks aligned to form a linear ridge parallel to the Atlantis II Fracture Zone. This platform has a flat, probably wave-cut, surface and locally is covered with a thin layer of sediments. The crustal age of Site 735 is inferred to be about $12 \mathrm{Ma}$ on the basis of magnetic anomaly patterns on the eastern transform wall. The surface feature is characterized by development of a steeply dipping foliation and a regular pattern of faults and joints, (Robinson, Von Herzen, et al., 1989). The section drilled in Hole 735B was originally divided into six lithologic units on the basis of primary igneous modal mineralogy, mineral and bulk chemical compositions, and degree and style of deformation (Robinson, Von Herzen, et al., 1989). Dick et al. (this volume) redescribed the entire core at the Ocean Drilling Repository, dividing it into six units, three of which were further subdivided into two to four subunits. In this paper, this lithostratigraphic division is employed in the description and discussion.

\section{PETROGRAPHY}

Gabbros from Hole $735 \mathrm{~B}$ can be divided into primitive gabbros (olivine-bearing gabbro, olivine gabbro, and troctolite) and evolved gabbros (gabbronorite, pigeonite gabbro, olivine iron-titanium (Fe-Ti) oxide gabbro). Olivine gabbros mostly without $\mathrm{Fe}-\mathrm{Ti}$ oxide are the main constituent of the hole. These two groups can be discriminated by the presence or absence of $\mathrm{Fe}-\mathrm{Ti}$ oxides and by the compositions of plagioclase, clinopyroxene, and olivine which exhibit bimodal populations in An mol\% $(100 \times \mathrm{Ca} /(\mathrm{Ca}+\mathrm{Na}+\mathrm{K}))$ of plagioclase and $\mathrm{Mg} \#(100 \times \mathrm{Mg} /(\mathrm{Mg}+\mathrm{Fe}))$ of mafic minerals (Fig. 4). As described later, the contacts between olivine gabbro and $\mathrm{Fe}-\mathrm{Ti}$ oxide gabbro generally are sharp (mineralogical gradients are confined to zones less than $1 \mathrm{~cm}$ ) resulting in few gabbros with intermediate compositions.

Cinopyroxenes in Fe-Ti oxide gabbros are generally subhedral to euhedral and have (001) exsolution lamellae and irregular orthopyroxene patches (Fig. 22 of Robinson, Von Herzen, et al., 1989), whereas those in olivine gabbro are generally anhedral and have no (001) exsolution lamellae.

\section{Gabbronorite}

Gabbronorite consists mainly of orthopyroxene, clinopyroxene, plagioclase, and Fe-Ti oxides (PI. 1, Fig. 1). Modal abundances of $\mathrm{Fe}-\mathrm{Ti}$ oxide are generally less than a few percent. The oxides exhibit scattered local concentration that defines a thin layer, which is parallel to the lamination. Trace amounts of olivine are rarely present. Reddish-brown amphibole is present as a minor phase at the rim of or partially replacing clinopyroxene. Zircon is present as an isolated euhedral grain in some gabbronorites. Orthopyroxene is subhedral to anhedral and exhibits various types of intergrowth with clinopyroxene. The most common type of intergrowth (0.1-1 $\mathrm{mm}$ in size) is characterized by a host orthopyroxene and optically continuous clinopyroxene having a poikilitic appearance (e.g., Sample 118-735B-76R-4, 12-19 cm). The margins of euhedral orthopyroxene rarely exhibit fine intergrowths (10-60 $\mu \mathrm{m}$ in size) with optically continuous clinopyroxene (Sample 118-735B-19R-5, 47-50 cm).

A rare poikilitic gabbronorite occurs as an intrusion into olivine gabbro (118-735B-74R-6 [Piece 1 through Piece 4C]). It consists of euhedral clinopyroxene, euhedral plagioclase, and 5- to $10-\mathrm{mm}$ oikocrysts of orthopyroxene containing abundant slightly corroded plagioclase and opaque minerals as chadacrysts and very rare clinopyroxene chadacrysts. Euhedral apatite is also present. Euhedral to subhedral magnetite and ilmenite are homogeneously distributed, being independent of orthopyroxene oikocrysts. Such euhedral Fe-Ti oxides are rare among the rest of the Fe-Ti oxide gabbros from Hole $735 \mathrm{~B}$, whose $\mathrm{Fe}-\mathrm{Ti}$ oxides are generally anhedral and fill the interstitial spaces between the silicate minerals.

A gabbronorite sample (Sample 118-735B-76R-1, 63-70 $\mathrm{cm}$ ), which is in contact with olivine gabbro, contains an anhedral grain of olivine surrounded by an intergrowth of orthopyroxene and Fe-Ti oxide (PI. 1, Fig. 4). This corona structure is located $1 \mathrm{~cm}$ from the contact. The occurrence of the corona structure at the contact suggest a reaction of olivine in the olivine gabbro with the evolved melt that crystallized gabbronorite. A similar orthopyroxene-magnetite 

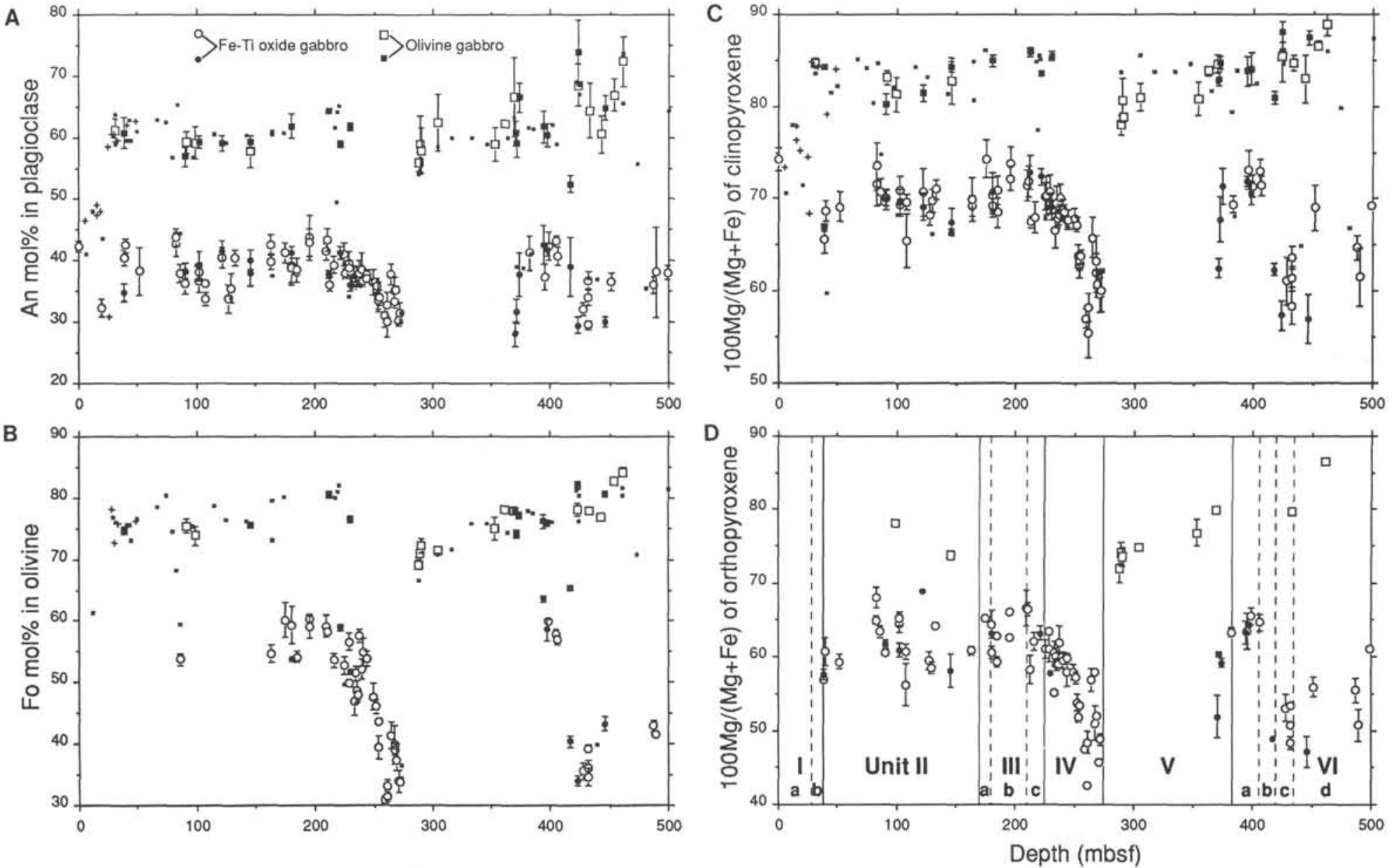

Figure 2. Downhole mineralogical variations (average An content in plagioclase (A) and average $\mathrm{Mg} /(\mathrm{Mg}+\mathrm{Fe}$ ) ratios for the main mafic minerals (B-D)) for gabbros from Hole 735B. Solid symbols indicate data near the contact between olivine gabbro and iron-titanium oxide gabbro. The data for olivine gabbros and troctolites in contact with iron-titanium oxide gabbro are analyses of cores 1-3 cm away from the contact. Bars indicate standard deviations. The unit boundaries (Dick et al., this volume) are shown in (D). Small solid squares in (A), (B), and (C) are the data obtained by P. S. Meyer at MIT (Bloomer et al., this volume). Pluses in Unit I are for fairly deformed and metamorphosed samples, original rock types of which are difficult to identify. 
- Gabbronorite

口 Olivine gabbronorite

- Disseminated Fe-Ti oxide olivine gabbro

- Olivine pigeonite gabbro

- Pigeonite gabbro
$\Delta$ Interstitial ol-bearing $\mathrm{Fe}$-Ti oxide gabbro I

+ Interstitial ol-bearing $\mathrm{Fe}$ - Ti oxide gabbro II

A Olivine Fe-Ti oxide gabbro

× Olivine $F_{\theta}$-Ti oxide microgabbro

A

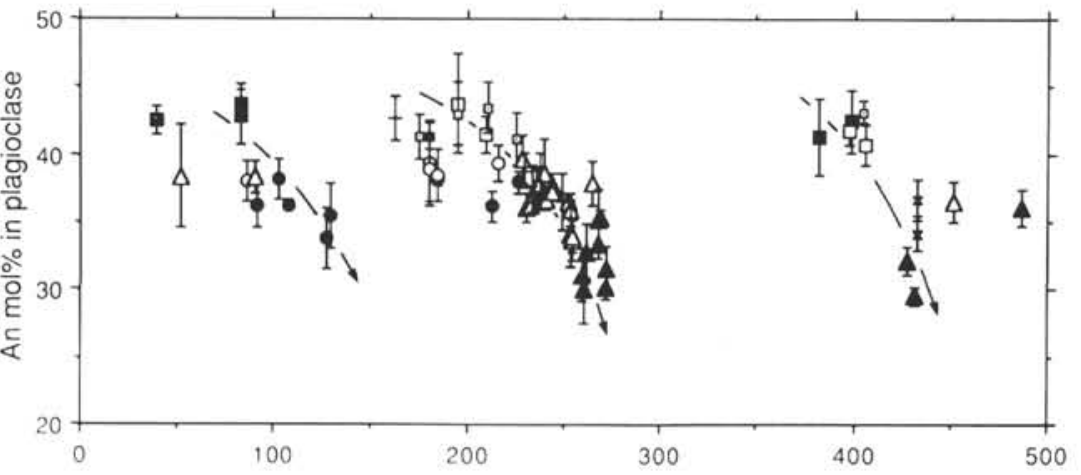

B

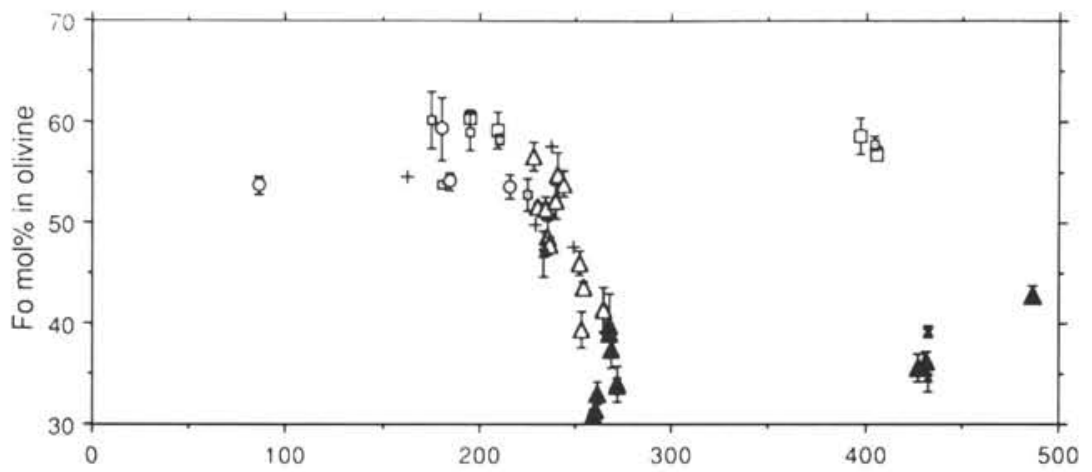

C

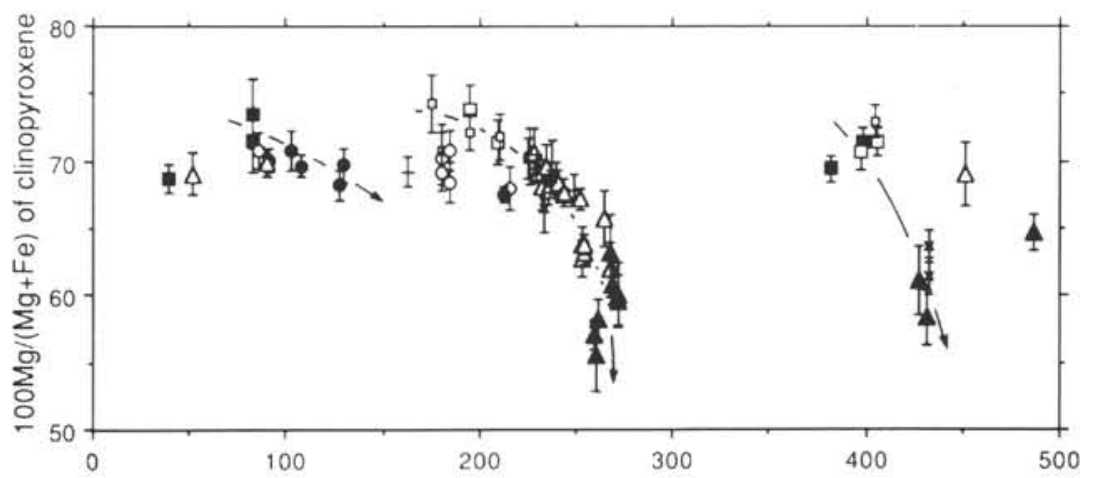

D

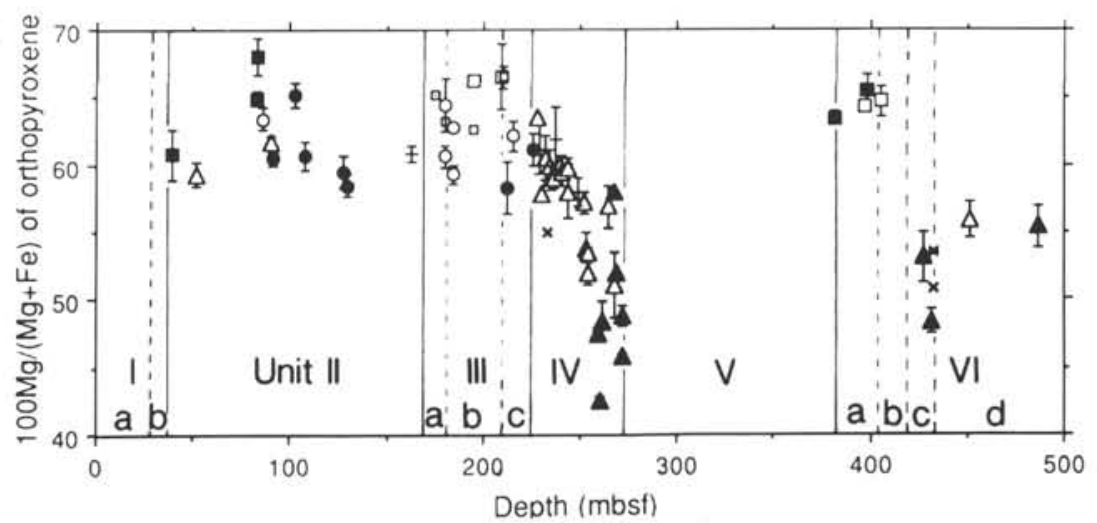

Figure 3. Downhole mineralogical variations (average An content in plagioclase (A) and average $\mathrm{Mg} /(\mathrm{Mg}+\mathrm{Fe})$ ratios of the main mafic minerals (B-D)) for Fe-Ti oxide gabbros from Hole 735B. Interstitial olivine-bearing Fe-Ti oxide gabbro II contains, but I does not have a corona structure. The corona structure consists of calcium-poor pyroxenes (inverted pigeonite or orthopyroxene) surrounded by clinopyroxene, which is further surrounded by olivine. Intergrowth of olivine and clinopyroxene rarely surrounds calcium-poor pyroxenes. Bars indicate standard deviations. The unit boundaries (Dick et al., this volume) are shown in (D). Three main cycles are depicted with arrows in (A) and (C). 
intergrowth around primary cumulus olivine has been noted in several layered intrusions and has been interpreted as a reaction between cumulus olivine and pore liquid (e.g., Ambler and Ashley, 1977).

\section{Olivine Gabbronorite}

Olivine gabbronorite consists of olivine, orthopyroxene, clinopyroxene, plagioclase, and Fe-Ti oxides (Pl. 1, Fig. 2). Minor amounts of brown hornblende are included in clinopyroxene, which is commonly associated with the opaque minerals. Hornblende also occurs at the contact between clinopyroxene and interstitial Fe-Ti oxides. The modal abundance of $\mathrm{Fe}-\mathrm{Ti}$ oxides is generally less than a few percent. Texturally, Fe-Ti oxides are anhedral, except for those that are included in pyroxenes and are locally concentrated, defining a remarkable modal layering. Olivine is commonly present as isolated grains or aggregates. Orthopyroxene is anhedral to subhedral, and the subhedral grains are elongate and show preferred orientation. Anhedral orthopyroxene is poikilitic and encloses plagioclase, olivine, and opaque minerals. Olivine gabbronorite commonly exhibits lamination and/or size and modal layering. In some layered specimens (e.g., Sample $118-735 B-43 R-3,95-102 \mathrm{~cm}$ ), olivine is present as an interstitial phase rimming opaque minerals in the olivine-poor and opaque-rich upper portion. In another layered specimen (Sample 118-735B-45R-1, 5-12 cm), a lower olivine gabbronorite layer is in contact with an opaque-rich pigeonite gabbro layer without olivine. The layer boundary is nearly horizontal and is marked by a sudden increase in opaque phases. Weak lamination, defined by elongate clinopyroxene, plagioclase, and Fe-Ti oxides, is nearly vertical and thus oblique to the layer boundary. The modal abundance of orthopyroxene decreases downward suddenly in one layered specimen (Sample 118$735 \mathrm{~B}-40 \mathrm{R}-5,0-8 \mathrm{~cm}$ ) and creates the appearance of disseminated $\mathrm{Fe}-\mathrm{Ti}$ oxide olivine gabbro, which will be described later. In this specimen, the Fe-Ti oxide is rich in the olivine gabbronorite layer, but is poor in the disseminated oxide olivine gabbro layer.

\section{Disseminated Fe-Ti Oxide Gabbro}

This gabbro consists of olivine, clinopyroxene, $\mathrm{Fe}-\mathrm{Ti}$ oxides, \pm orthopyroxene, and brown hornblende as an accessory primary phase (PI. 1, Fig. 3). Disseminated Fe-Ti oxide olivine gabbro has a modal abundance similar to olivine gabbro, but shows more evolved mineralogical characteristics and always contains minor amounts of $\mathrm{Fe}-\mathrm{Ti}$ oxides. Its modal abundance also is similar to an olivine $\mathrm{Fe}$-Ti oxide gabbro, except for the difference in the opaque abundance and mineral chemistries. The modal abundance of $\mathrm{Fe}$-Ti oxides is mostly less than $1 \%$. Orthopyroxene is present (less than 1\%) as anhedral grains, often in contact with olivine or clinopyroxene. Olivine is present as isolated grains or in aggregates. Disseminated $\mathrm{Fe}$-Ti oxide olivine gabbro commonly shows layering and a marked lamination. Olivine shows local concentrations in layers parallel to other types of modal or size layering. Magmatic lamination is often bowed and commonly oblique to the layer boundaries. One disseminated Fe-Ti oxide olivine gabbro (Sample 118-735B$40 \mathrm{R}-5,0-8 \mathrm{~cm})$ is in contact with upper olivine gabbronorite. The disseminated $\mathrm{Fe}-\mathrm{Ti}$ oxide olivine gabbro contains slightly more sodic plagioclase and Fe-rich mafic minerals than the olivine gabbronorite.

\section{Olivine Pigeonite Gabbro}

Olivine pigeonite gabbro consists mainly of olivine, inverted pigeonite, clinopyroxene, plagioclase, $\mathrm{Fe}-\mathrm{Ti}$ oxides, and \pm orthopyroxene. Modal abundance of the Fe-Ti oxides is variable and ranges from $1 \%$ to $5 \%$, which is distinctly higher than that of gabbronorite, olivine gabbronorite, and disseminated $\mathrm{Fe}$-Ti oxide olivine gabbro. The modal abundance of olivine is commonly less than $5 \%$, but some gabbros exhibit marked concentration of olivine, up to $70 \%$, giving rise to wehrlitic lithology. Olivine and $\mathrm{Fe}-\mathrm{Ti}$ oxides show local concentrations forming thin, olivine and/or opaque-rich layers. Olivine is present either as isolated aggregates or as interstitial grains generally associated with opaque minerals.In rare cases, olivine occurs in intergrowths with clinopyroxene in close proximity to inverted pigeonite. Inverted pigeonite is present as subhedral isolated grains (PI. 1, Fig. 5) or in cores of clinopyroxenes sharing its crystallographic c axis; thus (001) clinopyroxene exsolution lamellae in inverted pigeonite have the same extinction position as its host (PI. 1, Fig. 6). The contacts between host clinopyroxene and inverted pigeonite are fairly irregular. This mode of occurrence of inverted pigeonite, which is more common in pigeonite gabbro and olivine-bearing Fe-Ti oxide gabbro, suggests that the pigeonite became unstable at some stage of crystallization and started to corrode, and then clinopyroxene grew over it. Such corroded inverted pigeonite in clinopyroxene is also observed in olivine $\mathrm{Fe}-\mathrm{Ti}$ oxide gabbro, but is quite rare. Modal abundance of inverted pigeonite ranges from $1 \%$ to $7 \%$. In one specimen of olivine pigeonite gabbro (Sample 118$735 \mathrm{~B}-45 \mathrm{R}-1,5-12 \mathrm{~cm}$ ), olivine and pigeonite appear to be incompatible and are present in different layers. The pigeonite-bearing layer is rich in opaque minerals in contrast to the olivine-rich layer. In a remarkably laminated specimen (Sample 118-735B-38R-4, 24-28 cm), containing a 5-mm-thick olivine and an opaque-rich layer (steeply inclining at $60^{\circ}$ ), inverted pigeonite occurs within $1 \mathrm{~cm}$ above the olivine-rich bands. Below this, orthopyroxene appears instead of inverted pigeonite, both of which are further sandwiched by disseminated $\mathrm{Fe}-\mathrm{Ti}$ oxide olivine gabbro.

\section{Pigeonite Gabbro}

Pigeonite gabbro consists mainly of inverted pigeonite, clinopyroxene, \pm orthopyroxene, plagioclase, and Fe-Ti oxides (Figs. 19A 19B in Robinson, Von Herzen, et al., 1989). Olivine is absent and trace amounts of brown amphibole occur at the rim of, or included in, clinopyroxene. Euhedral apatite is rarely present. Modal abundance of $\mathrm{Fe}-\mathrm{Ti}$ oxides ranges from $3 \%$ to $20 \%$, which is distinctly greater than that of the gabbros described above. They are anhedral filling interstitial spaces between pyroxenes and plagioclase. The contacts between the Fe-Ti oxides and pyroxenes are bowed and are characterized by the common occurrence of cusps of Fe-Ti oxides projecting into clinopyroxene. Inverted pigeonite occurs either as anhedral single grains enclosed by clinopyroxene or as isolated euhedral-to-subhedral grains commonly associated with the Fe-Ti oxides. The modal abundance of inverted pigeonite is commonly less than a few percent, but rarely reaches $15 \%$ (e.g., Sample 118-735B-24R-2, 120-126 $\mathrm{cm}$ ). Pigeonite gabbros are generally coarser (with grains up to $30 \mathrm{~mm}$ ) than the other types of gabbros (Table 1). Intergrowth of Fe-Ti oxides and calcium-poor pyroxene is rarely present. The intergrowth may be a product of a reaction between olivine and liquid (see discussion above under gabbronorite).

\section{Interstitial Olivine-Bearing Fe-Ti Oxide Gabbro}

This type of gabbro is characterized by the occurrence of small amounts of intercumulus olivine, commonly associated with Fe-Ti oxides (Pl. 2, Figs. 1 to 4). It consists of clinopyroxene, plagioclase, Fe-Ti oxides, olivine, \pm inverted pigeonite, and \pm orthopyroxene. The modal abundance of $\mathrm{Fe}-\mathrm{Ti}$ oxides varies from a few percent to $15 \%$. They are fairly 
anhedral, and fill the interstitial spaces between plagioclase and clinopyroxene. The modal abundance of olivine is less than a few percent. Olivine occurs as an interstitial phase between Fe-Ti oxides and clinopyroxene (Pl. 2, Fig. 1) or sometimes as a filmy mantle around oxides adjacent to plagioclase (50-500 $\mathrm{m} ; \mathrm{Pl}$. 2, Fig. 2). A similar occurrence of olivine has been reported from the Skaergaard Intrusion (Wager and Brown, 1967). Olivine is, furthermore, often present as a fine intergrowth with clinopyroxene, which sometimes surrounds inverted pigeonite (PI. 2, Fig. 4). Olivine is rarely present as a monomineralic aggregate. Clinopyroxene is subhedral and commonly rounded with cusps of $\mathrm{Fe}-\mathrm{Ti}$ oxides projecting into clinopyroxene. Inverted pigeonite and orthopyroxene are present in the cores of clinopyroxenes. They have fairly irregular corroded shapes (Pl. 2, Fig. 3). Some interstitial olivine-bearing $\mathrm{Fe}$ - $\mathrm{Ti}$ oxide gabbros have a corona structure exhibiting a reaction relation between calcium-poor pyroxene and silicate melt. Calcium-poor pyroxene (inverted pigeonite or orthopyroxene) is surrounded by clinopyroxene-olivine intergrowth, which is further surrounded by olivine (PI. 2, Fig. 4; Fig. 23 in Robinson, Von Herzen, et al., 1989). This type of corona structure is wholly or partly enclosed by Fe-Ti oxides. The intergrowth (without a core of calcium-poor pyroxene) is common for more than one-half of the interstitial olivine-bearing gabbros. Interstitial olivinebearing $\mathrm{Fe}$-Ti oxide gabbros often show modal and size layering or banding; plagioclase-poor, clinopyroxene- and opaque-rich bands are common. These gabbros are also characterized by well-developed igneous lamination which in most cases is parallel to the layering.

\section{Olivine Fe-Ti Oxide Gabbro}

Olivine $\mathrm{Fe}$-Ti oxide gabbro is characterized by the presence of abundant, large, euhedral to subhedral olivine (PI. 2, Fig. 5), suggesting that this olivine was a cumulus phase. Olivine $\mathrm{Fe}-\mathrm{Ti}$ oxide gabbro consists of olivine clinopyroxene $\mathrm{Fe}-\mathrm{Ti}$ oxides plagioclase, \pm orthopyroxene, and +inverted pigeonite and can be easily discriminated from olivine gabbro and disseminated Fe-Ti oxide olivine gabbro by its evolved chemical nature and by the occurrence of much more abundant Fe-Ti oxides. Brown hornblende and apatite are common minor phases and zircon is present in some olivine $\mathrm{Fe}$ - $\mathrm{Ti}$ oxide gabbros. In rare cases, the modal abundance of apatite reaches $2 \%-4 \%$, and it is present as an aggregate with $\mathrm{Fe}$-Ti oxides. The modal abundance of olivine ranges from a few percent to $10 \%$. Olivine also occurs as an interstitial phase that is commonly associated with Fe-Ti oxides. The modal abundance of Fe-Ti oxides ranges from a few percent to $20 \%$. These oxides are anhedral, filling interstitial spaces between the silicate minerals. Inverted pigeonite is rarely present, but if present, is always in the core of clinopyroxene as an anhedral corroded grain. Orthopyroxene also is present, rimming euhedral olivine crystals. Layering is not developed in olivine $\mathrm{Fe}-\mathrm{Ti}$ oxide gabbro, and the magmatic lamination is weak.

\section{Olivine Fe-Ti Oxide Microgabbro}

Olivine $\mathrm{Fe}$-Ti oxide microgabbro consists mainly of olivine, clinopyroxene, plagioclase, and Fe-Ti oxides (PI. 2, Fig. 6). Minor amounts of brown hornblende are also present. Calcium-poor pyroxenes are absent with the exception of irregular orthopyroxene patches in the clinopyroxene. Olivine is anhedral and commonly associated with Fe-Ti oxides. The microgabbro often exhibits layering and weak lamination. In medium-grained layers in contact with fine-grained layers, the olivine is clearly interstitial to clinopyroxene and plagioclase, indicating that the olivine $\mathrm{Fe}-\mathrm{Ti}$ oxide microgabbro is a fine-grained interstitial olivine-bearing $\mathrm{Fe}-\mathrm{Ti}$ oxide gabbro.

\section{Downhole Petrographic Variation}

Even though these Fe-Ti oxide gabbros occur mixed with olivine gabbros at various scales, they exhibit a regular pattern of downhole petrographic and mineral chemical variations. As the depth increases from Unit I to IV, the Fe-Ti oxide gabbros tend to become more evolved. Three major cycles can be identified (Fig. 3; Table 1). From Units I to IV, the types of gabbro change as follows: gabbronorite, olivinebearing $\mathrm{Fe}-\mathrm{Ti}$ oxide gabbro, olivine pigeonite gabbro, pigeonite gabbro (the first cycle), disseminated Fe-Ti oxide olivine gabbro, olivine gabbronorite, olivine pigeonite gabbro, pigeonite gabbro, olivine-bearing $\mathrm{Fe}$ - $\mathrm{Ti}$ oxide gabbro, and olivine Fe-Ti oxide gabbro (the second cycle) (Fig. 3, Table 1). Olivine $\mathrm{Fe}-\mathrm{Ti}$ oxide gabbro, the most evolved $\mathrm{Fe}-\mathrm{Ti}$ oxide gabbro, is in particular restricted to a $50-\mathrm{m}$ thick zone of massive $\mathrm{Fe}-\mathrm{Ti}$ oxide gabbro at the base of Unit IV. Below Unit V, the variation is more erratic but still shows the same downward tendency (the third cycle); gabbronorite, olivine gabbronorite, and disseminated $\mathrm{Fe}$-Ti oxide olivine gabbro are present in the shallower levels $(<400 \mathrm{mbsf})$, and olivinebearing $\mathrm{Fe}$-Ti oxide gabbro and olivine $\mathrm{Fe}$-Ti oxide gabbro are present in the deeper levels ( $>400 \mathrm{mbsf}$, Fig. 3; Table 1).

Modal abundances of $\mathrm{Fe}-\mathrm{Ti}$ oxides also show systematic downhole variations that follow the petrographic cycles mentioned above. Abundances increase from Unit I to the bottom of Unit II where pigeonite gabbro occurs. In Unit IIIB, where gabbronorite and disseminated $\mathrm{Fe}-\mathrm{Ti}$ oxide olivine gabbro occur, the abundances abruptly decrease and then increase again until reaching a maximum in the middle of Unit IV, where pigeonite gabbro and olivine-bearing oxide gabbro occur. Near the bottom of Unit IV, the abundances of Fe-Ti oxides tend to decrease. Below Unit V, the abundances show a steady increase downward. Modal abundances of olivine increase from Unit I to Unit IV, where the proportion of olivine reaches $20 \%$, with the exception of local concentrations (e.g., Sample 118-735B-20R-1, 111-114 cm). For Units V and VI, olivine tends to increase downward.

Fe-Ti oxide gabbros commonly exhibit magmatic lamination. This magmatic lamination is developed in Units III and IV (below $180 \mathrm{mbsf}$, down to $250 \mathrm{mbsf}$ ). In the Unit IV, the lamination is well-developed, but is very weak or absent near the bottom, where olivine Fe-Ti oxide gabbro is present. The lamination dips at $45^{\circ}$ in Unit III. The dip of this lamination gradually decreases from $45^{\circ}$ at the top of Unit IV to almost horizontal near the bottom of the unit (Robinson, Von Herzen, et al., 1989). The gradual decrease in the dips of magmatic lamination, deformational foliation, and stable magnetic inclination (all by $\sim 40^{\circ}$ ) towards the bottom of Unit IV (Robinson, Von Herzen, et al., 1989) suggest a progressive rotation possibly due to faulting along the mylonite zone at the bottom of Unit IV.

The primary grain size of $\mathrm{Fe}-\mathrm{Ti}$ oxide gabbros exhibits downhole variation (Table 1). The representative grain size (the most common grain size) of clinopyroxene ranges from 0.2 to $30 \mathrm{~mm}$. Grain size ranges 2 to $10 \mathrm{~mm}$ in Unit I and upper half of Unit II, 2 to $30 \mathrm{~mm}$ in the bottom half of Unit II, and 0.2 to $20 \mathrm{~mm}$ in Units III and IV. Thus, the maximum grain size first increases downward and then reaches a maximum at $\sim 130 \mathrm{mbsf}$, followed by a decrease to the bottom of Unit IV. The minimum grain size tends to decrease from Unit I to Unit IV. In Units V and VI, the grain size ranges from 0.3 to $10 \mathrm{~mm}$.

Fe-Ti oxide gabbro commonly shows size and/or modal banding on a scale of a few millimeters (Robinson, Von Herzen, et al., 1989). This type of banding is best developed in Units III and IV, where lamination is well developed (Table 1). 


\section{MINERAL CHEMISTRY}

Minerals were analyzed by an electron microprobe analyzer (JEOL JCMA 733 Mk-II) at the Geological Institute, the University of Tokyo, under the following conditions: $2-3 \mu \mathrm{m}$ beam size, $15 \mathrm{kV}$ accelerating voltage, $1.2 \times 10^{-8} \mathrm{~A}$ specimen current, and ZAF correction procedure. Other conditions are the same as those applied by Nakamura and Kushiro (1970). In the area analyses, the specimen stage was automatically driven at $20-150 \mu \mathrm{m} / \mathrm{s}$. The pixel size ranged from 10 to 100 $\mu \mathrm{m}$. The beam size ranged from 5 to $50 \mu \mathrm{m}$.

Major and minor element abundances in cumulus minerals in gabbros can be used as indicators of magma evolution, but first the effects of postcumulus crystallization and subsolidus reequilibration must be considered. In Hole $735 \mathrm{~B}$ gabbros, subsolidus effects are probably negligible for all elements in plagioclase and most elements (except for $\mathrm{Ca}$, $\mathrm{Mg}$, and $\mathrm{Fe}$ ) in clinopyroxene, because plagioclase and clinopyroxene exhibit magmatic zoning (rarely oscillatory) for these elements. Magnesium and iron in mafic minerals are most affected by subsolidus exchange reactions as indicated by the $\mathrm{Mg}-\mathrm{Fe}$ distribution coefficients. However, the good correlations of $\mathrm{Mg \# s}$ of all the mafic minerals indicate that the $\mathrm{Mg} \# \mathrm{~s}$ can be used as a parameter of degree of the magma evolution.

Clinopyroxene grains are typically strongly zoned toward their rims. Core compositions, therefore, are more representative of cumulus compositions and better indicators of magma evolution. So most of the clinopyroxene analyses are of cores. Olivine is always fairly homogeneous so rims and cores have not been discriminated in the following discussion. The analyses of orthopyroxenes are of subhedral cumulus grains (in gabbronorite or olivine gabbronorite), hosts of inverted pigeonites (in olivine pigeonite gabbro or pigeonite gabbro), patchy grains (in Fe-Ti oxide gabbro), and interstitial grains (in olivine gabbro and troctolite). Plagioclase in the Fe-Ti oxide gabbros generally exhibits normal zoning, so most of the analyses are of cores. Average chemical compositions of olivine, plagioclase, clinopyroxene, and orthopyroxene are listed in Tables 3 to 6 . In Table 2 average An mol\% of plagioclase and $\mathrm{Mg \# s}$ of mafic minerals are listed with the number of analyses for each mineral.

\section{Relationships Between Rock Type and Mineral Chemistry}

The mineral chemistry of Fe-Ti oxides gabbros from Hole 735B shows distinct correlation with rock types (modal variation) and textural characteristics (e.g., grain size and reaction texture). The An content in plagioclase and $\mathrm{Mg} \#$ of mafic minerals decrease with overlap in the following order: gabbronorite, olivine gabbronorite, disseminated $\mathrm{Fe}-\mathrm{Ti}$ oxide olivine gabbro, olivine pigeonite gabbro, pigeonite gabbro, interstitial olivine-bearing $\mathrm{Fe}-\mathrm{Ti}$ oxide gabbro, and olivine Fe-Ti oxide gabbro (Fig. 5). Olivine Fe-Ti oxide microgabbros have similar mineral chemistries to olivinebearing Fe-Ti oxide gabbros, but their plagioclase is slightly more An-rich. Olivine-bearing $\mathrm{Fe}-\mathrm{Ti}$ oxide gabbros with relatively unevolved mineralogical characteristics often exhibit corona structures (Pl. 2, Fig. 4; Fig. 5). Gabbronorites and olivine pigeonite gabbros that exhibit intergrowths of calcium-poor pyroxene and Fe-Ti oxides (rarely surrounding olivine) have mineralogical characteristics similar to the less evolved olivine-bearing $\mathrm{Fe}-\mathrm{Ti}$ oxide gabbros. The co-variation trend of An content in plagioclase and $\mathrm{Mg \#}$ of mafic minerals for the gabbros from Hole $735 \mathrm{~B}$ is nearly parallel to that of the layered series of the Skaergaard Intrusion (Wager and Brown, 1967; Naslund, 1976; Hoover, 1978), and is characterized by a rapid decrease in $\mathrm{Mg} \#$ of mafic minerals for relatively evolved gabbros with smaller variations in the An content of plagioclase, compared with olivine gabbro and troctolite (Fig. 4). These facts suggest that the Fe-Ti oxide gabbros were derived from the same magma which formed the host troctolites and olivine gabbros.

The variation of mineral chemistry, reaction texture, and appearance and disappearance of minerals all indicate that as crystallization proceeds, the liquidus mafic phases vary as follows: orthopyroxene + clinopyroxene \pm olivine, pigeonite + clinopyroxene \pm orthopyroxene \pm olivine, pigeonite + clinopyroxene, olivine + clinopyroxene. These changes in cumulus phase are similar to those observed in the Skaergaard Intrusion, although in Hole 735B, orthopyroxene was an important liquidus phase before pigeonite started to crystallize. Temporary cessation of olivine crystallization is suggested by either the complete absence of olivine (e.g., in pigeonite gabbros) or by the presence of interstitial olivine in place of isolated cumulus grains (e.g., in interstitial olivinebearing Fe-Ti oxide gabbros). This reaction relationship and the disappearance of olivine has been documented experimentally in the system $\mathrm{MgO}-\mathrm{FeO}-\mathrm{SiO}_{2}$ (Bowen and Schairer, 1935). The Fo content of olivine marking the disappearance and reappearance of olivine for Hole $735 \mathrm{~B}$ is nearly the same as for the Skaergaard Intrusion; Fo $=50-52$ and Fo $=$ $40-45$, respectively. The An content in plagioclase is, however, much more sodic than that of the Skaergaard Intrusion. The common occurrence of inverted pigeonite in the cores of clinopyroxenes in interstitial olivine-bearing $\mathrm{Fe}-\mathrm{Ti}$ oxide gabbro suggests restricted adcumulus growth and extensive reaction between cumulus pigeonite and interstitial evolved melt occurred. The $\mathrm{Mg \#}$ of mafic minerals marking the first appearance of pigeonite as a liquidus phase ranges from 60 to 70 , which indicates that the temperature of a magma crystallizing pigeonite or olivine pigeonite gabbros was approximately $1050^{\circ} \mathrm{C}$ (Davidson and Lindsley, 1989).

\section{Downhole Mineralogical Variations in the Fe-Ti Oxide Gabbros}

The primary minerals in the $\mathrm{Fe}$ - $\mathrm{Ti}$ oxide gabbros show systematic downhole chemical variations consistent with the downhole distribution of rock types (Fig. 3). The An content in plagioclase and $\mathrm{Mg \#}(100 \times \mathrm{Mg} /(\mathrm{Mg}+\mathrm{Fe}))$ of mafic minerals show positive correlations and tend to decrease from Unit I to the bottom of Unit IV, with two major cycles, which are characterized by progressive downward evolution (Fig. 3). These cycles are further subdivided into a few minor cycles. The start of each cycle is marked by an abrupt increase in An content and $\mathrm{Mg} \#$ of mafic minerals. Within a cycle, those values decrease gradually until they abruptly increase again, and the next cycle begins (Fig. 3). The cycles identified in Units I to IV are:. (1) from 75 to $125 \mathrm{mbsf},(2)$ from 175 to 184 mbsf, (3) from 195to 234 mbsf, (4) from 237to $260 \mathrm{mbsf}$, and (5) from 262 to $271 \mathrm{mbsf}$. In spite of these downward repetitions of mineral chemistry, An content and $\mathrm{Mg \#}$ of mafic minerals show a steady decrease as a whole until the bottom of Unit IV is reached and olivine Fe-Ti oxide gabbro occurs, which contains the most sodic plagioclase $\left(\mathrm{An}_{30}\right)$ and the most iron-rich olivine $\left(\mathrm{Fo}_{30}\right)$ in Hole 735B (Fig. 3). Below Unit V, An content and Mg\# of mafic minerals tend to decrease downward as in the case of Units I to IV. The downhole mineralogical variations of the Fe-Ti oxide gabbros are in marked contrast to those observed for the olivine gabbros and troctolites, which are characterized by two cycles showing a gradual downward increase in the An content of plagioclase and the $\mathrm{Mg} \#$ of mafic minerals (Fig. 2). 
Table 2. Average An mol\% of plagioclase and magnesium of mafic minerals in gabbros from Hole 735B.

\begin{tabular}{|c|c|c|c|c|c|c|c|c|c|c|c|c|c|c|}
\hline $\begin{array}{l}\text { Core, section, } \\
\text { interval }(\mathrm{cm})\end{array}$ & $\begin{array}{l}\text { Depth } \\
\text { (mbsf) }\end{array}$ & Rock type & $\begin{array}{c}\text { Fo } \\
(\mathrm{mol} \%)\end{array}$ & $\begin{array}{l}\text { Fo } \\
\text { SD }\end{array}$ & $\begin{array}{c}\text { No. } \\
\text { ol }\end{array}$ & $\underset{(\mathrm{mol} \%)}{\mathrm{An}}$ & $\begin{array}{l}\text { An } \\
\text { SD }\end{array}$ & $\begin{array}{c}\text { No. } \\
\mathrm{pl}\end{array}$ & $\underset{\mathrm{cpx}}{\mathrm{XMg}}$ & $\begin{array}{c}\mathrm{XMgc} \\
\mathrm{SD}\end{array}$ & $\begin{array}{l}\text { No. } \\
\text { cp }\end{array}$ & $\begin{array}{r}\mathrm{XMg} \\
\text { opx }\end{array}$ & $\begin{array}{c}\text { XMgo } \\
\text { SD }\end{array}$ & $\begin{array}{l}\text { No. } \\
\text { op }\end{array}$ \\
\hline \multicolumn{15}{|l|}{$118-735 \mathrm{~B}-$} \\
\hline $8 D-1,45-48$ & 31.29 & Ol gabbro & & & 0 & 61.23 & 1.92 & 8 & 84.70 & 0.60 & 3 & & & 0 \\
\hline $12 \mathrm{R}-1,45-47$ & 39.92 & Gabbronorite & & & 0 & 42.51 & 1.09 & 6 & 68.73 & 1.10 & 14 & 60.79 & 1.92 & 7 \\
\hline $14 \mathrm{R}-1,93-97$ & 51.98 & Inst of gabbro? & & & 0 & 38.36 & 3.88 & 3 & 69.12 & 1.61 & 6 & 59.41 & 0.91 & 4 \\
\hline $19 R-5,47-50$ & 83.02 & Gabbronorite & & & 0 & 42.76 & 2.01 & 5 & 71.60 & 2.34 & 8 & 64.97 & 0.56 & 8 \\
\hline $19 \mathrm{R}-5,55-60$ & 83.12 & Gabbronorite & & & 0 & 43.76 & 1.48 & 6 & 73.51 & 2.57 & 3 & 68.04 & 1.38 & 5 \\
\hline 20R-1, 111-114 & 85.89 & Pl wehrlite & 53.73 & 0.95 & 4 & 38.04 & 1.47 & 5 & 70.78 & 1.35 & 4 & 63.46 & 0.82 & 4 \\
\hline $21 \mathrm{R}-1-1,82-89$ OLGB & 90.47 & Ol gabbro & & & 0 & 56.95 & 1.57 & 4 & 80.22 & 1.11 & 4 & & & 0 \\
\hline 21R-1-2, 82-89 FETI & 90.47 & Inst of gabbro & & & 0 & 38.33 & 1.23 & 5 & 69.93 & 1.05 & 3 & 61.80 & 0.44 & 3 \\
\hline $21 \mathrm{R}-2,27-32$ & 91.06 & Pig gabbro & & & 0 & 36.23 & 1.68 & 5 & 70.10 & 0.86 & 3 & 60.52 & 0.52 & 5 \\
\hline $21 \mathrm{R}-2,49-51$ & 91.38 & Ol gabbro & 75.43 & 1.12 & 4 & 59.20 & 1.78 & 4 & 83.12 & 0.79 & 9 & & & 0 \\
\hline $22 \mathrm{R}-3,118-120$ & 99.00 & Ol gabbro & 73.81 & 1.61 & 5 & 59.17 & 2.60 & 6 & 81.31 & 1.88 & 7 & 78.15 & & 1 \\
\hline $23 \mathrm{R}-3,33-37$ & 102.61 & Pig gabbro & & & 0 & 36.74 & 1.89 & 5 & 69.40 & 1.23 & 9 & 64.54 & 1.16 & 7 \\
\hline 24R-2, 95-97 & 107.94 & Gabbronorite & & & 0 & 33.87 & 1.03 & 6 & 65.42 & 2.92 & 7 & 56.28 & 2.90 & 3 \\
\hline $24 \mathrm{R}-2,120-126$ & 108.20 & Pig gabbro & & & 0 & 36.24 & 0.40 & 4 & 69.66 & 0.83 & 4 & 60.69 & 1.02 & 4 \\
\hline $27 \mathrm{R}-1-1,26-33$ OLGB & 121.80 & Ol gabbro & & & 0 & 59.12 & 1.18 & 6 & 81.44 & 0.88 & 6 & & & 0 \\
\hline $28 \mathrm{R}-1,109-114$ & 127.47 & Pig gabbro & & & 0 & 33.80 & 2.28 & 5 & 68.25 & 1.17 & 4 & 59.51 & 1.19 & 3 \\
\hline $28 \mathrm{R}-3,72-77$ & 129.54 & Pig gabbro & & & 0 & 35.49 & 2.42 & 6 & 69.75 & 1.27 & 4 & 58.52 & 0.76 & 6 \\
\hline $31 \mathrm{R}-2-1,116-119$ OLGB & 145.94 & Ol gabbro & 75.50 & 0.40 & 4 & 59.25 & 1.07 & 4 & 84.23 & 0.55 & 2 & & & 0 \\
\hline $31 \mathrm{R}-2,120-122$ & 145.96 & Ol gabbro & & & 0 & 57.75 & 2.58 & 6 & 82.78 & 2.47 & 6 & 73.75 & & 0 \\
\hline $34 \mathrm{R}-4,8-12$ & 163.23 & Inst ol gb $+r$ & 54.67 & 1.36 & 6 & 42.63 & 1.64 & 13 & 69.27 & 1.11 & 15 & 60.83 & 0.62 & 9 \\
\hline $36 R-4,5-9$ & 174.80 & Diss ox ol gb & 60.17 & 2.87 & 7 & 41.34 & 1.68 & 8 & 74.32 & 2.06 & 6 & 65.24 & 0.12 & 2 \\
\hline 37R-3-1, 71-76 OLGB & 180.13 & Ol gabbro & & & 0 & 61.86 & 1.98 & 3 & 84.96 & 0.64 & 3 & & & 0 \\
\hline 37R-3-2, 71-76 FETI & 180.13 & Diss ox ol gb & 53.75 & 0.31 & 2 & 41.37 & 0.97 & 2 & 70.78 & 2.08 & 4 & 63.23 & 0.17 & 3 \\
\hline $37 \mathrm{R}-3,76-79$ & 180.18 & Ol pig gabbro & 59.35 & 3.07 & 4 & 39.29 & 3.15 & 7 & 70.30 & 1.93 & 5 & 64.43 & 1.90 & 2 \\
\hline $37 \mathrm{R}-3,80-82$ & 180.23 & Ol pig gabbro & & & 0 & 38.90 & 2.35 & 8 & 69.22 & 1.31 & 13 & 60.63 & 0.83 & 4 \\
\hline $38 \mathrm{R}-3,85-88$ & 184.25 & Ol pig gabbro & & & 0 & 38.18 & 0.51 & 5 & 68.47 & 1.55 & 5 & 59.30 & 0.70 & 3 \\
\hline $38 \mathrm{R}-4,24-28$ & 184.88 & Ol pig gabbro & 54.11 & 0.95 & 6 & 38.51 & 1.96 & 6 & 70.90 & 1.50 & 6 & 62.78 & 0.17 & 4 \\
\hline $40 \mathrm{R}-5,0-4$ & 195.45 & Ol gabbronort & 60.30 & 0.88 & 6 & 43.74 & 3.67 & 6 & 73.84 & 1.78 & 4 & 66.18 & 0.35 & 5 \\
\hline $40 \mathrm{R}-5,4-8$ & 195.49 & Diss ox ol gb & 59.00 & 1.85 & 10 & 42.99 & 2.31 & 8 & 72.20 & 1.36 & 4 & 62.65 & & 1 \\
\hline $43 \mathrm{R}-3,95-102$ & 209.45 & Ol gabbronort & 59.16 & 1.82 & 10 & 41.45 & 1.37 & 9 & 71.46 & 1.69 & 9 & 66.60 & 2.42 & 5 \\
\hline $43 R-4,64-66$ & 210.23 & Diss ox ol gb & 58.26 & 0.50 & 10 & 43.44 & 1.89 & 12 & 71.84 & 1.67 & 15 & 66.51 & 0.82 & 3 \\
\hline $44 \mathrm{R}-1-1,113-120 \mathrm{CLGB}$ & 212.13 & Ol gabbro & 80.40 & 0.52 & 3 & 64.28 & 0.29 & 3 & 85.92 & 0.45 & 3 & & & 0 \\
\hline $44 \mathrm{R}-2,16-24$ & 212.37 & Pig gabbro & & & 0 & 36.15 & 1.10 & 4 & 67.52 & 0.61 & 4 & 58.32 & 1.94 & 4 \\
\hline $45 \mathrm{R}-1,5-12$ & 216.07 & Ol pig gabbro & 53.53 & 1.17 & 4 & 39.31 & 1.38 & 7 & 68.01 & 1.71 & 4 & 62.13 & 1.14 & 5 \\
\hline 46R-1-1, 48-58 OLGB & 221.47 & Ol gabbro & & & 0 & 58.97 & 0.48 & 2 & 83.53 & & 1 & & & 0 \\
\hline 46R-1-2, 48-58 FETI & 221.47 & Diss ox ol gb? & 58.96 & 0.56 & 8 & 41.40 & 1.07 & 11 & 72.38 & 0.91 & 9 & 63.25 & 0.94 & 4 \\
\hline $46 \mathrm{R}-3,121-128$ & 224.68 & Diss ox ol gb & 52.79 & 1.52 & 11 & 41.17 & 1.93 & 12 & 70.26 & 1.49 & 11 & & & 0 \\
\hline $46 \mathrm{R}-4,109-113$ & 225.83 & Pig gabbro & & & 0 & 37.94 & 0.86 & 6 & 70.36 & 2.08 & 4 & 61.13 & 1.24 & 3 \\
\hline $47 \mathrm{R}-2,117-127$ & 228.52 & Inst of gabbro & 56.65 & 1.43 & 4 & 39.70 & 1.79 & 6 & 70.76 & 1.78 & 9 & 63.57 & & 1 \\
\hline $47 \mathrm{R}-3,50-52$ OLGB & 229.20 & Ol gabbro & 79.83 & 0.44 & 7 & 63.97 & 1.30 & 8 & 85.17 & 0.46 & 4 & & & 0 \\
\hline $47 \mathrm{R}-3,56-61$ & 229.26 & Inst ob $\mathrm{gb}+\mathrm{r}$ & 49.90 & 0.54 & 5 & 38.82 & 1.30 & 8 & 69.46 & 1.05 & 10 & 61.14 & 1.84 & 6 \\
\hline $47 \mathrm{R}-3-1,143-149$ OLGB & 230.10 & Ol gabbro & 76.57 & 0.52 & 4 & 61.89 & 0.65 & 3 & 85.47 & 0.53 & 3 & & & 0 \\
\hline $47 \mathrm{R}-3-2,143-149$ FETI & 230.10 & Inst of gabbro & 51.67 & 0.28 & 2 & 36.04 & 1.00 & 10 & 69.14 & 1.47 & 7 & 57.81 & & 1 \\
\hline $48 R-2,56-65$ & 232.80 & Inst of gabbro & & & 0 & 36.25 & 0.86 & 8 & 68.09 & 1.74 & 5 & 60.53 & 1.68 & 5 \\
\hline $48 \mathrm{R}-2,109-113$ & 233.28 & Ol feti microgb & 46.98 & 2.30 & 8 & 37.44 & 1.71 & 7 & 66.55 & 1.90 & 8 & 55.07 & & 1 \\
\hline $48 \mathrm{R}-3,112-116$ & 234.53 & Inst of gabbro & 51.46 & 1.13 & 4 & 37.04 & 0.29 & 5 & 69.58 & 1.77 & 7 & 59.97 & 1.25 & 2 \\
\hline $48 \mathrm{R}-4,82-84$ & 235.51 & Inst of gabbro & 48.52 & 1.76 & 4 & 37.56 & 1.36 & 12 & 67.82 & 0.98 & 15 & 59.01 & 0.93 & 4 \\
\hline $49 \mathrm{R}-1,42-46$ & 236.34 & Inst of gabbro & 47.89 & 0.74 & 3 & 37.85 & 1.21 & 8 & 68.31 & 1.10 & 9 & 59.05 & 0.69 & 3 \\
\hline $49 R-2,94-100$ & 237.21 & Inst ol $\mathrm{gb}+\mathrm{r}$ & 57.57 & 1.02 & 6 & 37.98 & 2.08 & 7 & 70.00 & 1.61 & 6 & 61.92 & 2.36 & 3 \\
\hline $50 \mathrm{R}-2,43-47$ & 239.34 & Inst of gabbro & 52.11 & 1.68 & 6 & 38.59 & 2.63 & 11 & 68.81 & 1.07 & 7 & 60.00 & 0.58 & 4 \\
\hline $50 \mathrm{R}-3,62-67$ & 240.82 & Inst of gabbro & 54.81 & 2.28 & 4 & 36.64 & 0.79 & 6 & 68.50 & 0.88 & 6 & 59.54 & 1.12 & 5 \\
\hline 51R-1, 94-99 & 244.03 & Inst of glabbro & & & 0 & 37.77 & 0.81 & 4 & 67.50 & 0.50 & 7 & 58.03 & 2.03 & 9 \\
\hline 51R-1, 99-103 & 244.09 & Inst of glabbro & 53.85 & 1.32 & 6 & 37.19 & 0.24 & 7 & 67.75 & 1.03 & 7 & 59.86 & 0.73 & 3 \\
\hline $52 \mathrm{R}-\mathrm{I}, 91-100$ & 248.93 & Inst of $\mathrm{gb}+\mathrm{r}$ & 47.65 & 2.14 & 10 & 36.55 & 2.10 & 10 & 67.83 & 1.15 & 12 & 57.95 & 1.06 & 4 \\
\hline $52 \mathrm{R}-3,121-123$ & 251.60 & Inst of gabbro & 46.01 & 1.11 & 12 & 36.54 & 0.63 & 19 & 67.20 & 0.80 & 21 & 57.21 & 0.81 & 2 \\
\hline $52 R-4,88-94$ & 252.67 & Inst of gabbro & & & 0 & 35.96 & 1.19 & 8 & 63.84 & 1.24 & 8 & 53.83 & 1.10 & 2 \\
\hline $53 \mathrm{R}-1,47-54$ & 253.45 & Inst of gabbro & 39.40 & 1.85 & 6 & 34.15 & 2.43 & 8 & 62.80 & 1.37 & 11 & & & 0 \\
\hline $53 \mathrm{R}-1,123-127$ & 254.12 & Inst of gabbro & 43.63 & 0.52 & 3 & 33.65 & 1.56 & 7 & 63.18 & 0.86 & 5 & 51.93 & 0.83 & 2 \\
\hline $53 \mathrm{R}-2,31-39$ & 254.55 & Inst of gabbro & & & 0 & 34.02 & 1.26 & 6 & 63.77 & 0.78 & 5 & 53.43 & 0.41 & 2 \\
\hline 54R-1, 131-136 & 259.25 & Ol feti gabbro & 30.79 & 0.61 & 13 & 31.15 & 1.94 & 11 & 57.03 & 1.03 & 5 & 47.53 & 0.45 & 4 \\
\hline $54 \mathrm{R}-3,20-24$ & 260.84 & Ol feti gabbro & 31.41 & 0.82 & 6 & 30.12 & 2.67 & 4 & 55.49 & 2.69 & 6 & 42.61 & 0.23 & 3 \\
\hline $54 \mathrm{R}-3,125-127$ & 261.81 & Ol feti gabbro & 33.05 & 1.10 & 12 & 32.80 & 2.07 & 10 & 58.25 & 1.53 & 12 & 48.44 & 1.44 & 3 \\
\hline $54 \mathrm{R}-5,117-119$ & 264.39 & Inst of gabbro & 41.39 & 2.29 & 7 & 37.84 & 1.66 & 7 & 65.79 & 2.13 & 7 & 56.90 & 1.56 & 4 \\
\hline $55 \mathrm{R}-2,101-105$ & 267.50 & Inst of gabbro & 39.89 & 3.12 & 7 & 35.11 & 2.23 & 9 & 61.94 & 2.08 & 6 & 51.06 & 2.42 & 3 \\
\hline $55 \mathrm{R}-2,110-120$ & 267.62 & Ol feti gabbro & 39.04 & 0.92 & 5 & 33.42 & 1.18 & 6 & 63.20 & 2.89 & 8 & 57.95 & & 1 \\
\hline $55 \mathrm{R}-3,83-86$ & 268.81 & Ol feti gabbro & 37.41 & 1.78 & 6 & 35.27 & 0.56 & 8 & 60.77 & 1.45 & 6 & 51.98 & & 1 \\
\hline $56 \mathrm{R}-2,11-14$ & 271.52 & Ol feti gabbro & 33.94 & 1.77 & 8 & 30.22 & 0.85 & 12 & 59.59 & 1.90 & 11 & 45.81 & 0.13 & 2 \\
\hline $59 \mathrm{R}-3,70-72$ & 288.73 & Ol gabbro & 69.19 & 0.73 & 9 & 56.05 & 1.64 & 11 & 77.97 & 1.08 & 7 & 72.03 & 1.88 & 8 \\
\hline $59 \mathrm{R}-4,29-35$ & 289.65 & Ol gabbro & 70.88 & 1.25 & 8 & 58.79 & 4.72 & 10 & 80.62 & 2.36 & 12 & 74.13 & 1.45 & 4 \\
\hline $60 \mathrm{R}-1,18-20$ & 290.68 & Ol gabbro & 72.14 & 1.23 & 5 & 57.89 & 3.68 & 10 & 78.86 & 0.31 & 4 & 73.64 & 1.27 & 3 \\
\hline $62 \mathrm{R}-4,21-24$ & 304.30 & Ol gabbro & 71.43 & 0.51 & 5 & 62.38 & 4.62 & 4 & 80.99 & 1.44 & 5 & 74.89 & 0.16 & 2 \\
\hline $71 \mathrm{R}-2,82-84$ & 353.01 & Ol gabbro & 75.01 & 1.92 & 7 & 58.84 & 2.73 & 6 & 80.81 & 1.83 & 7 & 76.84 & 1.85 & 2 \\
\hline $72 \mathrm{R}-5,123-125$ & 362.15 & Ol gabbro & 78.04 & 0.18 & 4 & 62.17 & 0.49 & 4 & 83.81 & 0.53 & 4 & & & 0 \\
\hline $73 \mathrm{R}-3,73-75$ & 369.02 & Ol gabbro & 77.94 & 0.52 & 8 & 66.55 & 6.48 & 15 & 84.55 & 1.00 & 27 & 79.86 & 0.61 & 7 \\
\hline $73 R-4-1,82-87$ OLGB & 370.23 & Ol gabbro & 77.88 & 0.41 & 6 & 60.67 & 2.06 & 6 & 82.95 & 0.72 & 5 & & & 0 \\
\hline
\end{tabular}


Table 2 (continued).

\begin{tabular}{|c|c|c|c|c|c|c|c|c|c|c|c|c|c|c|}
\hline $\begin{array}{l}\text { Core, section, } \\
\text { interval }(\mathrm{cm})\end{array}$ & $\begin{array}{l}\text { Depth } \\
\text { (mbsf) }\end{array}$ & Rock type & $\begin{array}{c}\text { Fo } \\
(\mathrm{mol} \%)\end{array}$ & $\begin{array}{l}\text { Fo } \\
\text { SD }\end{array}$ & $\begin{array}{c}\text { No. } \\
\text { ol }\end{array}$ & $\underset{(\mathrm{mol} \%)}{\mathrm{An}}$ & $\begin{array}{l}\text { An } \\
\text { SD }\end{array}$ & $\begin{array}{c}\text { No. } \\
\mathrm{pl}\end{array}$ & $\begin{array}{c}\mathrm{XMg} \\
\mathrm{cpx}\end{array}$ & $\underset{\text { XD }}{\text { XMc }}$ & $\begin{array}{l}\text { No. } \\
\text { cp }\end{array}$ & $\begin{array}{r}\mathrm{XMg} \\
\text { opx }\end{array}$ & $\begin{array}{c}\text { XMgo } \\
\text { SD }\end{array}$ & $\begin{array}{l}\text { No. } \\
\text { op }\end{array}$ \\
\hline 73R-4-2, 82-87 FETI & 370.23 & Gabbronorite & & & 0 & 28.09 & 2.00 & 5 & 62.47 & 1.09 & 3 & 51.89 & 2.89 & \\
\hline $73 \mathrm{R}-5-1,72-78$ OLGB & 371.58 & Ol gabbro & 74.13 & 0.57 & 3 & 59.06 & 2.20 & 6 & 84.68 & 0.72 & 5 & & & 0 \\
\hline 73R- $5-2,72-78$ FETI & 371.58 & Gabbronorite & & & 0 & 31.80 & 2.04 & 5 & 67.73 & 2.41 & 8 & 60.43 & 0.34 & 2 \\
\hline $73 \mathrm{R}-7-1,0-5$ OLGB & 373.56 & Ol gabbro & 77.15 & 0.48 & 6 & 66.54 & 2.43 & 6 & & & 0 & & & 0 \\
\hline $74 \mathrm{R}-6,27-35$ & 382.13 & Poik gabbnort & & & 0 & 41.24 & 2.84 & 10 & 69.44 & 0.96 & 9 & 63.43 & 0.54 & 5 \\
\hline $76 \mathrm{R}-1-1,63-70$ OLGB & 394.69 & Ol gabbro & 76.10 & 1.08 & 3 & 61.77 & 2.59 & 4 & 83.80 & 1.60 & 4 & 81.26 & & 1 \\
\hline $76 \mathrm{R}-1-2,63-70 \mathrm{FETI}$ & 394.69 & Gabbronorite & 63.64 & 0.54 & 3 & 42.53 & 3.16 & 7 & 71.84 & 0.58 & 5 & 63.34 & 1.56 & 3 \\
\hline 76R-1, 70-73 FETI & 394.74 & Gabbronorite & & & 0 & 47.41 & 4.15 & 9 & 72.97 & 1.70 & 7 & 66.17 & 1.34 & 9 \\
\hline 76R-1, 99-110 FETI & 395.08 & Gabbronorite & & & 0 & 37.35 & 2.19 & 13 & 73.16 & 2.05 & 15 & 63.49 & 2.39 & 16 \\
\hline $76 \mathrm{R}-3-1,35-41$ OLGB & 397.06 & Ol gabbro & 75.86 & 0.59 & 5 & 60.31 & 1.93 & 6 & 84.07 & 1.74 & 2 & & & \\
\hline 76R-3-2, 35-4I FETI & 397.06 & Ol gabbronort & 58.55 & 1.81 & 7 & 41.74 & 0.98 & 6 & 70.63 & 1.32 & 5 & 64.34 & & 1 \\
\hline $76 R-4,12-19$ & 398.20 & Gabbronorite & 59.97 & 0.04 & 2 & 42.43 & 2.26 & 13 & 71.38 & 1.19 & 11 & 65.55 & 1.12 & 10 \\
\hline $77 \mathrm{R}-2,5-8$ & 404.96 & Diss ox ol gb & 57.89 & 0.77 & 7 & 43.15 & 0.81 & 3 & 73.01 & 1.21 & 4 & & & 0 \\
\hline 77R-2, 101-107 & 405.89 & Ol gabbronort & 56.87 & 0.72 & 9 & 40.64 & 1.50 & 7 & 71.42 & 1.02 & 15 & 64.68 & 1.11 & 5 \\
\hline $79 \mathrm{R}-2-1,55-61$ OLGB & 416.49 & Ol gabbro & 65.35 & 0.15 & 4 & 52.47 & 1.33 & 4 & 80.94 & 0.74 & 4 & & & 0 \\
\hline $79 \mathrm{R}-7-1,2-9$ OLGB & 422.82 & Ol gabbro & 82.03 & 0.62 & 8 & 74.01 & 5.07 & 12 & 88.05 & 1.12 & 5 & & & 0 \\
\hline 79R-7-2, 2-9 FETI & 422.82 & Ol gabbronort & 34.01 & 0.77 & 5 & 29.49 & 1.37 & 6 & 57.34 & 1.64 & 8 & & & 0 \\
\hline $79 \mathrm{R}-7,99-102$ & 423.74 & Troct. microgb & 78.07 & 0.96 & 9 & 68.56 & 3.44 & 28 & 85.37 & 2.78 & 5 & & & 0 \\
\hline $80 \mathrm{R}-3,67-71$ & 427.35 & Ol feti gabbro & 35.58 & 1.40 & 6 & 32.14 & 1.05 & 5 & 61.12 & 2.55 & 5 & 53.13 & 1.82 & 2 \\
\hline $80 R-6,130-135$ & 431.98 & Ol feti gabbro & 36.13 & 1.11 & 7 & 29.53 & 0.70 & 9 & 58.37 & 2.02 & 6 & 48.41 & 0.84 & 7 \\
\hline $80 R-7,10-18$ & 432.23 & Ol feti microgb & 34.55 & 1.41 & 6 & 34.11 & 1.27 & 8 & 61.39 & 1.34 & 7 & 50.87 & & 1 \\
\hline $80 \mathrm{R}-7,23-25$ & 432.32 & Ol feti microgb & 39.17 & 0.64 & 5 & 36.69 & 1.53 & 6 & 63.67 & 1.24 & 4 & 53.44 & 0.05 & 2 \\
\hline $81 \mathrm{R}-5,1-7$ & 433.54 & Ol gabbro & 77.86 & 0.45 & 10 & 64.40 & 4.53 & 16 & 84.70 & 0.85 & 26 & 79.80 & & 1 \\
\hline $81 R-7,64-66$ & 442.33 & Ol gabbro & 76.83 & 0.73 & 7 & 60.49 & 3.00 & 6 & 82.99 & 2.61 & 5 & & & \\
\hline $82 \mathrm{R}-3-1,0-5$ OLGB & 445.72 & Ol gabbro & 80.61 & 0.49 & 4 & 64.82 & 2.01 & 9 & 87.45 & 0.74 & 7 & & & 0 \\
\hline $82 \mathrm{R}-3-2,0-5$ FETI & 445.72 & Gabbronorite & 43.22 & 1.15 & 3 & 30.02 & 0.79 & 3 & 56.93 & 2.66 & 9 & 47.15 & 2.12 & 10 \\
\hline $83 R-2,3-9$ & 453.86 & Troctolite & 82.58 & 0.14 & 8 & 66.85 & 2.60 & 9 & 86.58 & 0.46 & 6 & & & $\mathbf{0}$ \\
\hline $83 \mathrm{R}-7,77-81$ & 460.84 & Troctolite & 84.20 & 0.74 & 11 & 72.44 & 4.07 & 10 & 88.91 & 1.21 & 8 & 86.57 & 0.16 & 2 \\
\hline $86 \mathrm{R}-4,123-130$ & 486.60 & Ol feti gabbro & 42.90 & 0.93 & 6 & 36.03 & 1.34 & 9 & 64.71 & 1.33 & 4 & 55.43 & 1.58 & 4 \\
\hline $86 \mathrm{R}-6,143-145$ & 489.57 & Inst of gabbro & 41.40 & 0.04 & 2 & 38.17 & 7.42 & 6 & 61.51 & 3.18 & 3 & 50.74 & 2.15 & \\
\hline
\end{tabular}

Note: The standard deviations and number of analyses for each specimen are also shown.

Abbreviations are: $\mathrm{SD}$, standard deviation; $\mathrm{Mg} \#, \mathrm{Mg} /(\mathrm{Mg}+\mathrm{Fe}) ; \mathrm{cpx}$ or cp, clinopyroxene; XMgc, $\mathrm{Mg} \#$ of clinopyroxene; XMgo, $\mathrm{Mg} \#$ of orthopyroxene; opx or op, orthopyroxene; No., number of analyses. Other abbreviations are the same as in Table 1. Contacting olivine gabbro and Fe-Ti oxide gabbro are indicated by "OLGB" and "FETI" in the interval column. Depth in meter below sea floor.

\section{Minor Element Abundance in Constituent Minerals}

\section{Clinopyroxene}

The $\mathrm{TiO}_{2}$ content of clinopyroxene in olivine gabbro increases as the An content in plagioclase and $\mathrm{Mg \#}$ of mafic minerals decrease (Fig. 6A). Clinopyroxene in troctolitic microgabbros exhibit a wide range in $\mathrm{TiO}_{2}$ from 0.5 to 1.4 $\mathrm{wt} \%$, with averages for individual samples as high as $1.1 \mathrm{wt} \%$. Clinopyroxenes in coarse troctolites exhibit a similar range in $\mathrm{TiO}_{2}$ as those in olivine gabbros but on average individual samples have lower $\mathrm{TiO}_{2}$ contents $(<0.6 \mathrm{wt} \%)$. The $\mathrm{TiO}_{2}$ content of clinopyroxene in the $\mathrm{Fe}$-Ti oxide gabbros tends to decrease as An content in plagioclase and $\mathrm{Mg} \#$ of mafic minerals decrease (Fig. 6A). $\mathrm{TiO}_{2}$ contents in clinopyroxene cores reach a maximum in pigeonite gabbros and interstitial olivine-bearing $\mathrm{Fe}-\mathrm{Ti}$ oxide gabbros, which are rich in $\mathrm{Fe}-\mathrm{Ti}$ oxides. $\mathrm{TiO}_{2}$ decreases remarkably as the $\mathrm{Mg} \#$ decreases in interstitial olivine-bearing $\mathrm{Fe}$-Ti oxide gabbros and olivine Fe-Ti oxide gabbros. Gabbronorite, olivine gabbronorite, and disseminated $\mathrm{Fe}-\mathrm{Ti}$ oxide olivine gabbro, all of which are relatively poor in Fe-Ti oxide, show a slight increase in $\mathrm{TiO}_{2}$ content of clinopyroxene as An content in plagioclase decreases.

For olivine gabbro and troctolite, the $\mathrm{TiO}_{2}$ content of clinopyroxene markedly increases from the core to the rim, whereas in $\mathrm{Fe}$ - $\mathrm{Ti}$ oxide gabbro, the $\mathrm{TiO}_{2}$ content is almost constant or decreases slightly. This change in the $\mathrm{TiO}_{2}$ zoning pattern and the variation in $\mathrm{TiO}_{2}$ content with $\mathrm{Mg} \#$ can be explained by the crystallization of $\mathrm{Fe}-\mathrm{Ti}$ oxides, which began during the crystallization of the gabbronorite and reached a maximum during the crystallization of pigeonite gabbro or interstitial olivine-bearing Fe-Ti oxide gabbro.

The $\mathrm{Na}_{2} \mathrm{O}$ content of clinopyroxenes increases as the $\mathrm{Mg} \#$ decreases from olivine gabbro to pigeonite gabbro (Fig. 6B). A further decrease in $\mathrm{Mg \#}$ of clinopyroxene leads to a slight decrease in $\mathrm{Na}_{2} \mathrm{O}$ content. The $\mathrm{Na}_{2} \mathrm{O}$ content of clinopyroxene, consequently, reaches a maximum in the pigeonite gabbro, whose grain size is the largest among the Fe-Ti oxide gabbros. There is a consistent relationship between $\mathrm{Na}_{2} \mathrm{O}$ content and the grain size of clinopyroxene; the $\mathrm{Na}_{2} \mathrm{O}$ content increases with an increase in grain size. This relationship suggests that the $\mathrm{Mg} \#-\mathrm{Na}_{2} \mathrm{O}$ relationship of clinopyroxene is controlled not only by magma composition but by sub-liquidus processes, such as adcumulus growth or reaction with trapped melt. The $\mathrm{Na}_{2} \mathrm{O}$ content tends to be high in troctolite as compared to that for olivine gabbros.

The $\mathrm{Al}_{2} \mathrm{O}_{3}$ content of clinopyroxene decreases steadily from troctolite to olivine $\mathrm{Fe}-\mathrm{Ti}$ oxide gabbro as the $\mathrm{Mg} \#$ of clinopyroxene decreases; the clinopyroxene of the troctolite contains 3 to $4 \mathrm{wt} \% \mathrm{Al}_{2} \mathrm{O}_{3}$, whereas that of the olivine $\mathrm{Fe}-\mathrm{Ti}$ oxide gabbro contains only 1.0 to $1.6 \mathrm{wt} \% \mathrm{Al}_{2} \mathrm{O}_{3}$ (Fig. 7A). This decrease in $\mathrm{Al}_{2} \mathrm{O}_{3}$ content is probably due to the fractionation of plagioclase in each batch of magma, which is consistent with the decrease in $\mathrm{Al}_{2} \mathrm{O}_{3}$ content in MORB glass with the decrease in $\mathrm{MgO}$ content (BVSP, 1981). Clinopyroxene in olivine gabbros showing vermicular intergrowth with orthopyroxene tends to be poor in $\mathrm{Al}_{2} \mathrm{O}_{3}$.

The $\mathrm{MnO}$ content in clinopyroxene shows a steady increase from troctolite to olivine $\mathrm{Fe}$-Ti oxide gabbro, as $\mathrm{Mg \# s}$ decrease; from $0.1 \mathrm{wt} \%$ for clinopyroxenes in troctolites to 0.5 wt $\%$ for those in olivine Fe-Ti oxide gabbros (Fig. 7B). The 
Table 3. Average chemical composition of olivine in gabbros from Hole 735B.

\begin{tabular}{|c|c|c|c|c|c|c|c|}
\hline \multirow{2}{*}{$\begin{array}{l}\text { Core, section, } \\
\text { interval }(\mathrm{cm})\end{array}$} & \multirow[b]{2}{*}{ Rock type } & \multicolumn{6}{|c|}{ Olivine } \\
\hline & & $\mathrm{SiO}_{2}$ & $\mathrm{FeO}$ & $\mathrm{MnO}$ & $\mathrm{MgO}$ & $\mathrm{CaO}$ & $\mathrm{NiO}$ \\
\hline \multicolumn{8}{|l|}{ 118-735B- } \\
\hline $76 \mathrm{R}-4,12-19$ & Gabbronorite & $\begin{array}{r}36.16 \\
0.19\end{array}$ & $\begin{array}{r}35.87 \\
0.07\end{array}$ & $\begin{array}{l}0.548 \\
0.105\end{array}$ & $\begin{array}{r}30.16 \\
0.00\end{array}$ & $\begin{array}{l}0.031 \\
0.017\end{array}$ & \\
\hline \multirow[t]{2}{*}{$40 R-5,0-4$} & Olivine gabbronorite & 36.74 & 35.12 & 0.585 & 29.52 & 0.038 & 0.013 \\
\hline & & 0.12 & 0.44 & 0.061 & 0.28 & 0.022 & 0.026 \\
\hline \multirow[t]{2}{*}{$43 \mathrm{R}-3,95-102$} & Olivine gabbronorite & 36.39 & 35.37 & 0.617 & 28.57 & 0.043 & 0.021 \\
\hline & & 0.42 & 1.43 & 0.049 & 1.16 & 0.009 & 0.036 \\
\hline 76R-3, 34-41 CT & Olivine gabbronorite & 36.40 & 35.41 & 0.598 & 28.07 & 0.038 & 0.006 \\
\hline & & 0.26 & 1.47 & 0.049 & 0.95 & 0.011 & 0.012 \\
\hline $77 \mathrm{R}-2,101-107$ & Olivine gabbronorite & 36.26 & 37.09 & 0.651 & 27.44 & 0.029 & \\
\hline & & 0.16 & 0.76 & 0.032 & 0.33 & 0.016 & \\
\hline $36 \mathrm{R}-4,5-9$ & Dissem ox ol gabbro & 36.76 & 35.31 & 0.691 & 28.85 & 0.041 & \\
\hline & & 0.17 & 1.46 & 0.038 & 1.06 & & \\
\hline 37R-3, 71-76 CT & Dissem ox ol gabbro & 36.15 & 39.69 & 0.645 & 25.88 & 0.055 & \\
\hline & & 0.23 & 0.52 & 0.050 & 0.01 & 0.022 & \\
\hline $40 \mathrm{R}-5,4-8$ & Dissem ox ol gabbro & 36.52 & 35.52 & 0.626 & 28.90 & 0.037 & 0.011 \\
\hline & & 0.33 & 1.46 & 0.067 & 1.06 & 0.023 & 0.011 \\
\hline $43 R-4,64-66$ & Dissem ox ol gabbro & 36.51 & 36.03 & 0.591 & 28.21 & 0.046 & 0.033 \\
\hline & & 0.23 & 0.39 & 0.038 & 0.37 & 0.015 & 0.023 \\
\hline $46 \mathrm{R}-3,121-128$ & Dissem ox ol gabbro & 35.99 & 39.23 & 0.673 & 24.59 & 0.046 & 0.016 \\
\hline & & 0.25 & 1.10 & 0.061 & 0.99 & 0.023 & 0.027 \\
\hline $77 \mathrm{R}-2,5-8$ & Dissem ox ol gabbro & 36.50 & 36.13 & 0.619 & 27.67 & 0.074 & \\
\hline & & 0.22 & 0.64 & 0.031 & 0.36 & 0.019 & \\
\hline $20 \mathrm{R}-1,111-114$ & $\mathrm{Ol}$ pigeonite gabbro & 36.18 & 39.29 & 0.680 & 25.61 & 0.065 & \\
\hline & & 0.18 & 0.54 & 0.016 & 0.65 & & \\
\hline 37R-3, 76-79 & Ol pigeonite gabbro & 36.08 & 36.06 & 0.692 & 26.58 & 0.051 & \\
\hline & & 0.56 & 1.17 & 0.035 & 0.22 & 0.019 & \\
\hline $38 R-4,24-28$ & Ol pigeonite gabbro & 36.13 & 39.08 & 0.646 & 25.86 & 0.045 & 0.050 \\
\hline & & 0.16 & 0.68 & 0.048 & 0.64 & 0.007 & 0.042 \\
\hline $45 \mathrm{R}-1,5-12$ & Ol pigeonite gabbro & 35.95 & 39.00 & 0.724 & 25.20 & 0.056 & 0.025 \\
\hline & & 0.18 & 1.27 & 0.093 & 0.50 & 0.023 & 0.029 \\
\hline $47 \mathrm{R}-2,117-127$ & Interst ol ox gabbro I & 36.22 & 37.01 & 0.699 & 27.12 & 0.054 & 0.010 \\
\hline & & 0.18 & 1.79 & 0.053 & 0.30 & 0.017 & \\
\hline $47 \mathrm{R}-3,143-149 \mathrm{CT}$ & Interst ol ox gabbro I & 36.40 & 36.88 & 0.579 & 27.68 & 0.037 & 0.024 \\
\hline & & 0.57 & 2.87 & 0.058 & 2.15 & 0.020 & 0.027 \\
\hline $48 R-3,112-116$ & Interst ol ox gabbro I & 35.80 & 40.98 & 0.688 & 24.36 & 0.059 & 0.030 \\
\hline & & 0.13 & 1.64 & 0.060 & 0.32 & 0.010 & 0.030 \\
\hline $48 R-4,82-84$ & Interst ol ox gabbro I & 35.10 & 42.21 & 0.628 & 22.33 & 0.046 & 0.008 \\
\hline & & 0.17 & 1.06 & 0.046 & 1.02 & 0.023 & 0.009 \\
\hline $49 R-1,42-46$ & Interst ol ox gabbro I & 35.41 & 41.19 & 0.666 & 23.01 & 0.054 & 0.013 \\
\hline & & 0.38 & 0.45 & 0.082 & 0.43 & 0.006 & 0.023 \\
\hline $50 \mathrm{R}-2,43-47$ & Interst ol ox gabbro I & 36.12 & 39.96 & 0.670 & 24.64 & 0.048 & \\
\hline & & 0.33 & 1.06 & 0.038 & 1.07 & 0.011 & \\
\hline $50 R-3,62-67$ & Interst ol ox gabbro I & 35.99 & 38.67 & 0.634 & 26.32 & 0.047 & 0.009 \\
\hline & & 0.25 & 1.85 & 0.073 & 1.24 & 0.032 & 0.011 \\
\hline 51R-1, 94-99 & Interst ol ox gabbro I & 36.08 & 39.30 & 0.705 & 25.73 & 0.051 & 0.001 \\
\hline & & 0.24 & 1.12 & 0.080 & 0.71 & 0.015 & 0.001 \\
\hline $52 \mathrm{R}-3,12 \mathrm{I}-123$ & Interst ol ox gabbro I & 35.06 & 44.15 & 0.713 & 21.11 & 0.031 & 0.016 \\
\hline & & 0.20 & 0.75 & 0.026 & 0.65 & 0.027 & 0.020 \\
\hline $53 R-1,47-54$ & Interst ol ox gabbro I & 34.54 & 48.50 & 0.879 & 17.71 & 0.037 & \\
\hline & & 0.43 & 0.89 & 0.083 & 1.08 & 0.026 & \\
\hline $53 \mathrm{R}-1,123-127$ & Interst ol ox gabbro I & 34.75 & 45.82 & 0.877 & 19.90 & 0.030 & 0.008 \\
\hline & & 0.20 & 1.08 & 0.109 & 0.22 & 0.026 & 0.009 \\
\hline $54 R-5,117-119$ & Interst ol ox gabbro I & 34.29 & 46.65 & 0.827 & 18.50 & 0.069 & 0.002 \\
\hline & & 0.53 & 1.33 & 0.077 & 1.23 & 0.019 & 0.004 \\
\hline $55 \mathrm{R}-2,101-105$ & Interst ol ox gabbro I & 34.10 & 46.87 & 0.883 & 17.48 & 0.078 & 0.007 \\
\hline & & 0.29 & 1.94 & 0.048 & 1.57 & 0.014 & 0.016 \\
\hline $34 \mathrm{R}-4,8-12$ & Interst ol ox gabbro II & 36.04 & 38.17 & 0.681 & 25.84 & 0.051 & 0.019 \\
\hline & & 0.19 & 0.86 & 0.069 & 0.86 & 0.010 & 0.027 \\
\hline $47 \mathrm{R}-3,56-61$ & Interst ol ox gabbro II & 35.44 & 41.77 & 0.796 & 23.34 & 0.055 & \\
\hline & & 0.24 & 0.66 & 0.051 & 0.20 & 0.022 & \\
\hline $49 \mathrm{R}-2,94-100$ & Interst ol ox gabbro II & 36.57 & 37.02 & 0.635 & 28.11 & 0.045 & 0.033 \\
\hline & & 0.23 & 0.89 & 0.040 & 0.65 & 0.014 & 0.040 \\
\hline $52 \mathrm{R}-1,91-100$ & Interst ol ox gabbro II & 35.11 & 43.56 & 0.696 & 21.91 & 0.066 & 0.034 \\
\hline & & 0.36 & 1.32 & 0.055 & 1.01 & 0.026 & 0.028 \\
\hline $54 \mathrm{R}-1,131-136$ & Olivine oxide gabbro & 32.95 & 52.16 & 1.159 & 13.19 & 0.061 & 0.006 \\
\hline & & 0.14 & 0.40 & 0.044 & 0.20 & 0.031 & 0.011 \\
\hline $54 \mathrm{R}-3,20-24$ & Olivine oxide gabbro & 33.39 & 54.03 & 1.125 & 12.93 & 0.093 & 0.007 \\
\hline & & 0.33 & 0.88 & 0.105 & 1.22 & 0.031 & 0.009 \\
\hline $54 \mathrm{R}-3,125-127$ & Olivine oxide gabbro & 33.00 & 51.23 & 1.058 & 14.15 & 0.068 & 0.023 \\
\hline & & 0.31 & 0.49 & 0.039 & 0.49 & 0.021 & 0.021 \\
\hline $55 \mathrm{R}-2,110-120$ & Olivine oxide gabbro & 34.07 & 48.51 & 0.943 & 17.43 & 0.064 & 0.003 \\
\hline & & 0.21 & 0.81 & 0.047 & 0.39 & 0.006 & 0.006 \\
\hline $55 \mathrm{R}-3,83-86$ & Olivine oxide gabbro & 34.17 & 49.77 & 0.857 & 16.70 & 0.071 & 0.012 \\
\hline & & 0.29 & 0.93 & 0.036 & 0.95 & 0.010 & 0.013 \\
\hline
\end{tabular}


Table 3 (continued).

\begin{tabular}{|c|c|c|c|c|c|c|c|}
\hline \multirow{2}{*}{$\begin{array}{l}\text { Core, section, } \\
\text { interval }(\mathrm{cm})\end{array}$} & \multirow[b]{2}{*}{ Rock type } & \multicolumn{6}{|c|}{ Olivine } \\
\hline & & $\mathrm{SiO}_{2}$ & $\mathrm{FeO}$ & $\mathrm{MnO}$ & $\mathrm{MgO}$ & $\mathrm{CaO}$ & $\mathrm{NiO}$ \\
\hline \multirow[t]{2}{*}{$56 \mathrm{R}-2,49-52$} & Olivine oxide gabbro & 33.87 & 51.29 & 0.998 & 15.12 & 0.055 & 0.016 \\
\hline & & 0.29 & 1.03 & 0.034 & 0.89 & 0.012 & 0.017 \\
\hline \multirow[t]{2}{*}{$56 \mathrm{R}-2,49-52$} & Olivine oxide gabbro & 33.57 & 51.94 & 1.041 & 14.74 & 0.047 & 0.010 \\
\hline & & 0.11 & 0.44 & 0.034 & 0.20 & 0.010 & 0.021 \\
\hline \multirow[t]{2}{*}{$80 R-3,67-71$} & Olivine oxide gabbro & 33.59 & 50.69 & 1.147 & 15.71 & 0.069 & \\
\hline & & 0.14 & 1.47 & 0.119 & 0.55 & 0.023 & \\
\hline \multirow[t]{2}{*}{$80 \mathrm{R}-6,130-135$} & Olivine oxide gabbro & 34.00 & 50.68 & 1.181 & 16.09 & 0.067 & \\
\hline & & 0.21 & 1.00 & 0.041 & 0.55 & 0.017 & \\
\hline \multirow[t]{2}{*}{$86 \mathrm{R}-4,123-130$} & Olivine oxide gabbro & 34.36 & 45.79 & 0.859 & 19.29 & 0.055 & \\
\hline & & 0.30 & 1.37 & 0.061 & 0.29 & 0.031 & \\
\hline \multirow[t]{2}{*}{$48 \mathrm{R}-2,109-113$} & Ol oxide microgabbro & 35.32 & 43.52 & 0.705 & 21.66 & 0.051 & 0.036 \\
\hline & & 0.37 & 1.47 & 0.066 & 1.26 & 0.013 & 0.021 \\
\hline \multirow[t]{2}{*}{$80 \mathrm{R}-7,10-18$} & Ol oxide microgabbro & 33.66 & 51.80 & 0.984 & 15.10 & 0.051 & \\
\hline & & 0.22 & 1.03 & 0.070 & 0.57 & 0.018 & \\
\hline \multirow[t]{2}{*}{$80 \mathrm{R}-7,23-25$} & Ol oxide microgabbro & 33.74 & 47.71 & 0.721 & 17.40 & 0.052 & 0.026 \\
\hline & & 0.37 & 0.46 & 0.057 & 0.28 & 0.013 & 0.035 \\
\hline \multirow[t]{2}{*}{$83 R-7,77-81$} & Troctolite & 40.61 & 15.19 & 0.238 & 45.41 & 0.037 & 0.206 \\
\hline & & 0.14 & 0.68 & 0.028 & 0.50 & 0.011 & 0.032 \\
\hline \multirow[t]{2}{*}{$83 R-2,3-9$} & Troctolite & 40.18 & 16.75 & 0.276 & 44.56 & 0.054 & \\
\hline & & 0.20 & 0.15 & 0.051 & 0.22 & 0.021 & \\
\hline \multirow[t]{2}{*}{$79 \mathrm{R}-7,99-102$} & Troctolite & 39.26 & 20.30 & 0.357 & 40.56 & 0.057 & \\
\hline & & 0.27 & 0.87 & 0.040 & 0.99 & 0.027 & \\
\hline \multirow[t]{2}{*}{$80 \mathrm{R}-1,41-45$} & Ol gabbro-Troctolite & 39.79 & 17.49 & 0.301 & 43.13 & 0.042 & 0.152 \\
\hline & & 0.23 & 0.50 & 0.029 & 0.40 & 0.011 & 0.042 \\
\hline \multirow[t]{2}{*}{ 73R-3, 73-75 } & Vermic cpx ol gabbro & 39.47 & 20.54 & 0.302 & 40.70 & 0.039 & 0.089 \\
\hline & & 0.19 & 0.52 & 0.028 & 0.30 & 0.015 & 0.033 \\
\hline \multirow[t]{2}{*}{$81 R-5,1-7$} & Vermic cpx ol gabbro & 39.37 & 20.58 & 0.294 & 40.61 & 0.039 & 0.093 \\
\hline & & 0.16 & 0.40 & 0.031 & 0.43 & 0.011 & 0.032 \\
\hline \multirow[t]{2}{*}{ 7IR-2, 82-84 } & Vermic cpx ol gabbro & 38.82 & 22.05 & 0.336 & 39.06 & 0.039 & 0.096 \\
\hline & & 0.11 & 0.23 & 0.028 & 0.41 & 0.010 & 0.039 \\
\hline \multirow[t]{2}{*}{$81 R-7,64-66$} & Vermic cpx ol gabbro & 38.95 & 21.24 & 0.295 & 39.87 & 0.033 & 0.060 \\
\hline & & 0.24 & 0.61 & 0.031 & 0.43 & 0.019 & 0.015 \\
\hline \multirow[t]{2}{*}{$62 \mathrm{R}-4,21-24$} & Olivine gabbro & 38.74 & 26.24 & 0.415 & 36.50 & 0.062 & \\
\hline & & 0.10 & 0.54 & 0.047 & 0.34 & 0.008 & \\
\hline \multirow[t]{2}{*}{$72 R-5,123-125$} & Olivine gabbro & 39.78 & 20.81 & 0.317 & 41.49 & 0.058 & \\
\hline & & 0.19 & 0.39 & 0.024 & 0.35 & 0.023 & \\
\hline \multirow[t]{2}{*}{$59 \mathrm{R}-4,29-35$} & Olivine gabbro & 38.56 & 26.45 & 0.414 & 36.13 & 0.047 & 0.082 \\
\hline & & 0.26 & 0.96 & 0.042 & 0.96 & 0.016 & 0.029 \\
\hline $21 \mathrm{R}-2,49-51$ & Olivine gabbro & 38.44 & 22.04 & 0.325 & 37.90 & 0.034 & 0.094 \\
\hline & & 0.41 & 0.60 & 0.047 & 1.21 & 0.011 & 0.045 \\
\hline $60 \mathrm{R}-1,18-20$ & Olivine gabbro & 38.28 & 25.65 & 0.389 & 35.78 & 0.039 & 0.062 \\
\hline & & 0.26 & 0.58 & 0.042 & 1.04 & 0.007 & 0.020 \\
\hline $59 \mathrm{R}-3,70-72$ & Olivine gabbro & 38.25 & 27.90 & 0.411 & 35.14 & 0.043 & 0.070 \\
\hline & & 0.06 & 0.61 & 0.049 & 0.51 & 0.014 & 0.028 \\
\hline
\end{tabular}

Note: Standard deviations are also shown below the average of oxide weight percent.

Abbreviations are: dissem ox ol gabbro, disseminated Fe-Ti oxide olivine gabbro; ol pigeonite gabbro, olivine pigeonite gabbro; interst ol ox gabbro I, interstitial olivine-bearing Fe-Ti oxide gabbro; olivine oxide gabbro, olivine Fe-Ti oxide gabbro; ol oxide microgabbro, olivine Fe-Ti oxide microgabbro; ol gabbro, olivine gabbro; vermic cpx ol gabbro, vermicular clinopyroxene olivine gabbro; CT, near contacts between Fe-Ti oxide gabbro and olivine gabbro.

$\mathrm{MnO}$ content in both olivine and orthopyroxene also increases as $\mathrm{Mg \# s}$ decrease.

The $\mathrm{Cr}_{2} \mathrm{O}_{3}$ content markedly decreases as the $\mathrm{Mg} \#$ of clinopyroxene decreases as rock types change from troctolite to olivine gabbro (Fig 7C). The content of $\mathrm{Cr}_{2} \mathrm{O}_{3}$ is less than $0.1 \mathrm{wt} \%$ for all of the $\mathrm{Fe}$-Ti oxide gabbros. This remarkable decrease can be explained by early-stage fractionation of chromian spinel and clinopyroxene, as observed in troctolite and magnesian olivine gabbros (Robinson, Von Herzen, et al., 1989).

\section{Orthopyroxene}

As in the case of clinopyroxene, the $\mathrm{Al}_{2} \mathrm{O}_{3}$ content of orthopyroxene decreases as its $\mathrm{Mg} \#$ decreases (Fig. 8B). In olivine gabbro, orthopyroxenes contain up to $2.0 \mathrm{wt} \% \mathrm{Al}_{2} \mathrm{O}_{3}$, whereas they contain less than $0.5 \mathrm{wt} \% \mathrm{Al}_{2} \mathrm{O}_{3}$ in the most evolved olivine $\mathrm{Fe}-\mathrm{Ti}$ oxide gabbro. The $\mathrm{MnO}$ content of orthopyroxene increases steadily from $0.2 \mathrm{wt} \%$ in troctolites to $1.0 \mathrm{wt} \%$ in olivine $\mathrm{Fe}-\mathrm{Ti}$ oxide gabbros as the $\mathrm{Mg \#}$ decreases (Fig. 8C). The $\mathrm{TiO}_{2}$ content of orthopyroxene shows a similar variation to that in clinopyroxene; as the $\mathrm{Mg}$ \# decreases, it reaches a maximum in pigeonite gabbros and olivine pigeonite gabbros (up to $0.4 \mathrm{wt} \%$ ) and then decreases in interstitial olivine-bearing $\mathrm{Fe}$ - $\mathrm{Ti}$ oxide gabbros and olivine $\mathrm{Fe}$-Ti oxide gabbros (Fig. 8A). In the olivine Fe-Ti oxide gabbros the $\mathrm{TiO}_{2}$ content is less than $0.2 \mathrm{wt} \%$. The $\mathrm{Cr}_{2} \mathrm{O}_{3}$ contents of orthopyroxenes show the same variation as those in clinopyroxenes; decreasing from 0.25 wt $\%$ in troctolites to less than $0.1 \mathrm{wt} \%$ in $\mathrm{Fe}-\mathrm{Ti}$ oxide gabbros.

\section{Plagioclase}

Plagioclase in $\mathrm{Fe}-\mathrm{Ti}$ oxide gabbros commonly appears dusty in thin section in plane light (Pl. ', Fig. 2). The dusty appearance is due to the abundance of tiny exsolution lamellae of opaque iron oxides, suggesting that the plagioclase in $\mathrm{Fe}-\mathrm{Ti}$ 
Table 4. Average chemical composition of plagioclase in gabbros from Hole 735B.

\begin{tabular}{|c|c|c|c|c|c|c|c|}
\hline \multirow{2}{*}{$\begin{array}{l}\text { Core, section, } \\
\text { interval }(\mathrm{cm})\end{array}$} & \multirow[b]{2}{*}{ Rock type } & \multicolumn{6}{|c|}{ Plagioclase (wt\%) } \\
\hline & & $\mathrm{SiO}_{2}$ & $\mathrm{Al}_{2} \mathrm{O}_{3}$ & $\mathrm{Fe}_{2} \mathrm{O}_{3}$ & $\mathrm{CaO}$ & $\mathrm{Na}_{2} \mathrm{O}$ & $\mathrm{K}_{2} \mathrm{O}$ \\
\hline \multicolumn{8}{|l|}{$118-735 \mathrm{~B}-$} \\
\hline \multirow[t]{2}{*}{$12 \mathrm{R}-1,45-47$} & \multirow[t]{2}{*}{ Gabbronorite } & 58.57 & 26.29 & 0.190 & 8.40 & 6.20 & 0.116 \\
\hline & & 0.29 & 0.27 & 0.052 & 0.16 & 0.23 & 0.021 \\
\hline \multirow[t]{2}{*}{$19 \mathrm{R}-5,47-50$} & Gabbronorite & 58.40 & 26.16 & 0.189 & 8.19 & 6.67 & 0.060 \\
\hline & & 0.81 & 0.59 & 0.045 & 0.72 & 0.42 & 0.039 \\
\hline $19 \mathrm{R}-5,55-60$ & Gabbronorite & 58.32 & 27.14 & 0.159 & 8.96 & 6.29 & 0.112 \\
\hline & & 0.35 & 0.16 & 0.056 & 0.29 & 0.26 & 0.024 \\
\hline $74 \mathrm{R}-6,27-35$ & Gabbronorite & 58.62 & 26.05 & 0.301 & 8.17 & 6.35 & 0.138 \\
\hline & & 0.60 & 0.32 & 0.120 & 0.52 & 0.40 & 0.019 \\
\hline $76 \mathrm{R}-4,12-19$ & Gabbronorite & 56.74 & 26.36 & 0.322 & 8.58 & 6.49 & 0.088 \\
\hline & & 0.50 & 0.41 & 0.134 & 0.38 & 0.21 & 0.023 \\
\hline $40 \mathrm{R}-5,0-4$ & Olivine gabbronorite & 57.41 & 26.49 & 0.223 & 8.72 & 6.13 & 0.107 \\
\hline & & 0.80 & 0.61 & 0.066 & 0.67 & 0.46 & 0.012 \\
\hline $43 R-3,95-102$ & Olivine gabbronorite & 57.80 & 26.04 & 0.171 & 8.26 & 6.38 & 0.098 \\
\hline & & 0.57 & 0.17 & 0.032 & 0.25 & 0.20 & 0.014 \\
\hline 76R-3, 34-41 CT & Olivine gabbronorite & 58.15 & 26.02 & 0.179 & 8.31 & 6.34 & 0.111 \\
\hline & & 0.48 & 0.27 & 0.053 & 0.16 & 0.18 & 0.015 \\
\hline $77 R-2,101-107$ & Olivine gabbronorite & 58.29 & 26.08 & 0.195 & 8.19 & 6.55 & 0.099 \\
\hline & & 0.27 & 0.26 & 0.043 & 0.31 & 0.24 & 0.018 \\
\hline $36 \mathrm{R}-4,5-9$ & Dissem ox ol gabbro & 58.10 & 26.60 & 1.183 & 8.41 & 6.56 & 0.055 \\
\hline & & 0.32 & 0.21 & 0.122 & 0.36 & 0.23 & 0.032 \\
\hline $37 \mathrm{R}-3,71-76 \mathrm{CT}$ & Dissem ox ol gabbro & 58.95 & 26.52 & 0.117 & 8.29 & 6.35 & 0.099 \\
\hline & & 0.28 & 0.04 & 0.097 & 0.10 & 0.18 & 0.042 \\
\hline $40 \mathrm{R}-5,4-8$ & Dissem ox ol gabbro & 57.59 & 26.31 & 0.249 & 8.52 & 6.18 & 0.108 \\
\hline & & 0.57 & 0.29 & 0.214 & 0.40 & 0.30 & 0.018 \\
\hline $43 R-4,64-66$ & Dissem ox ol gabbro & 57.62 & 26.49 & 0.179 & 8.84 & 6.31 & 0.083 \\
\hline & & 0.57 & 0.43 & 0.045 & 0.40 & 0.21 & 0.014 \\
\hline $46 \mathrm{R}-3,121-128$ & Dissem ox ol gabbro & 58.74 & 26.20 & 0.226 & 8.29 & 6.48 & 0.104 \\
\hline & & 0.60 & 0.37 & 0.105 & 0.40 & 0.20 & 0.036 \\
\hline $77 R-2,5-8$ & Dissem ox ol gabbro & 58.46 & 26.48 & 0.173 & 8.59 & 6.20 & 0.093 \\
\hline & & 0.54 & 0.22 & 0.072 & 0.58 & 0.13 & 0.020 \\
\hline $20 \mathrm{R}-1,111-114$ & Ol pigeonite gabbro & 59.30 & 25.59 & 0.105 & 7.47 & 6.74 & 0.072 \\
\hline & & 0.67 & 0.43 & 0.051 & 0.29 & 0.21 & 0.035 \\
\hline $37 \mathrm{R}-3,76-79$ & Ol pigeonite gabbro & 58.49 & 26.12 & 0.198 & 8.01 & 6.79 & 0.076 \\
\hline & & 0.75 & 0.40 & 0.144 & 0.59 & 0.43 & 0.034 \\
\hline $37 \mathrm{R}-3,80-82$ & $\mathrm{Ol}$ pigeonite gabbro & 58.23 & 25.67 & 0.136 & 7.76 & 6.69 & 0.078 \\
\hline & & 0.76 & 0.35 & 0.042 & 0.48 & 0.26 & 0.050 \\
\hline $38 \mathrm{R}-3,85-88$ & $\mathrm{Ol}$ pigeonite gabbro & 57.45 & 25.24 & 0.231 & 7.69 & 6.83 & 0.097 \\
\hline & & 0.24 & 0.11 & 0.059 & 0.02 & 0.24 & 0.028 \\
\hline $38 \mathrm{R}-4,24-28$ & Ol pigeonite gabbro & 58.71 & 25.80 & 0.126 & 7.70 & 6.72 & 0.105 \\
\hline & & 0.47 & 0.30 & 0.050 & 0.43 & 0.20 & 0.040 \\
\hline $45 \mathrm{R}-1,5-12$ & $\mathrm{Ol}$ pigeonite gabbro & 58.89 & 25.66 & 0.207 & 7.78 & 6.55 & 0.144 \\
\hline & & 0.40 & 0.26 & 0.064 & 0.30 & 0.21 & 0.013 \\
\hline $21 \mathrm{R}-2,27-32$ & Pigeonite gabbro & 60.13 & 25.71 & 0.208 & 7.41 & 7.10 & 0.155 \\
\hline & & 0.38 & 0.08 & 0.079 & 0.47 & 0.23 & 0.031 \\
\hline $23 \mathrm{R}-3,34-37$ & Pigeonite gabbro & 58.71 & 25.54 & 0.206 & 7.77 & 6.89 & 0.100 \\
\hline & & 0.48 & 0.27 & 0.049 & 0.27 & 0.21 & 0.044 \\
\hline $24 \mathrm{R}-2,120-126$ & Pigeonite gabbro & 59.55 & 25.45 & 0.149 & 7.42 & 7.15 & 0.090 \\
\hline & & 0.26 & 0.15 & 0.069 & 0.16 & 0.14 & 0.027 \\
\hline $28 \mathrm{R}-1,109-114$ & Pigeonite gabbro & 59.95 & 25.12 & 0.176 & 6.93 & 7.42 & 0.137 \\
\hline & & 0.41 & 0.35 & 0.053 & 0.48 & 0.29 & 0.054 \\
\hline $28 \mathrm{R}-3,72-77$ & Pigeonite gabbro & 59.53 & 25.52 & 0.166 & 7.27 & 7.24 & 0.172 \\
\hline & & 0.61 & 0.58 & 0.038 & 0.46 & 0.27 & 0.019 \\
\hline $44 R-2,16-24$ & Pigeonite gabbro & 59.24 & 24.88 & 0.138 & 7.37 & 7.05 & 0.214 \\
\hline & & 0.35 & 0.28 & 0.049 & 0.28 & 0.15 & 0.076 \\
\hline $46 \mathrm{R}-4,109-113$ & Pigeonite gabbro & 59.76 & 25.36 & 0.239 & 7.52 & 6.71 & 0.134 \\
\hline & & 0.49 & 0.24 & 0.203 & 0.07 & 0.22 & 0.020 \\
\hline $14 \mathrm{R}-1,93-97$ & Interst ol ox gabbro I & 59.17 & 25.79 & 0.149 & 7.62 & 6.67 & 0.129 \\
\hline & & 1.11 & 0.69 & 0.087 & 0.80 & 0.38 & 0.050 \\
\hline $21 \mathrm{R}-1,82-89 \mathrm{CT}$ & Interst ol ox gabbro I & 60.01 & 25.58 & 0.132 & 7.61 & 6.73 & 0.073 \\
\hline & & 0.14 & 0.16 & 0.096 & 0.14 & 0.36 & 0.053 \\
\hline $47 R-2,117-127$ & Interst ol ox gabbro I & 58.56 & 26.07 & 0.149 & 7.95 & 6.57 & 0.135 \\
\hline & & 0.24 & 0.14 & 0.077 & 0.32 & 0.35 & 0.016 \\
\hline $47 \mathrm{R}-3,143-149 \mathrm{CT}$ & Interst ol ox gabbro I & 59.23 & 25.69 & 0.205 & 7.54 & 7.22 & 0.099 \\
\hline & & 0.32 & 0.19 & 0.089 & 0.21 & 0.24 & 0.041 \\
\hline $48 R-2,56-65$ & Interst ol ox gabbro I & 60.06 & 25.58 & 0.211 & 7.30 & 7.01 & 0.135 \\
\hline & & 0.34 & 0.23 & 0.047 & 0.22 & 0.11 & 0.023 \\
\hline $48 \mathrm{R}-3,112-116$ & Interst ol ox gabbro I & 59.64 & 25.67 & 0.141 & 7.50 & 6.94 & 0.155 \\
\hline & & 0.16 & 0.06 & 0.042 & 0.14 & 0.06 & 0.021 \\
\hline $48 R-4,82-84$ & Interst ol ox gabbro I & 59.55 & 25.37 & 0.167 & 7.47 & 6.80 & 0.094 \\
\hline & & 0.59 & 0.32 & 0.079 & 0.27 & 0.26 & 0.041 \\
\hline $49 \mathrm{R}-1,42-46$ & Interst ol ox gabbro I & 59.40 & 25.41 & 0.231 & 7.52 & 6.74 & 0.122 \\
\hline & & 0.48 & 0.44 & 0.092 & 0.26 & 0.15 & 0.036 \\
\hline $50 \mathrm{R}-2,43-47$ & Interst ol ox gabbro I & 60.17 & 25.77 & 0.210 & 7.65 & 6.69 & 0.097 \\
\hline & & 0.97 & 0.43 & 0.088 & 0.52 & 0.30 & 0.044 \\
\hline
\end{tabular}


Table 4 (continued).

\begin{tabular}{|c|c|c|c|c|c|c|c|}
\hline \multirow{2}{*}{$\begin{array}{l}\text { Core, section, } \\
\text { interval }(\mathrm{cm})\end{array}$} & \multirow[b]{2}{*}{ Rock type } & \multicolumn{6}{|c|}{ Plagioclase $(w t \%)$} \\
\hline & & $\mathrm{SiO}_{2}$ & $\mathrm{Al}_{2} \mathrm{O}_{3}$ & $\mathrm{Fe}_{2} \mathrm{O}_{3}$ & $\mathrm{CaO}$ & $\mathrm{Na}_{2} \mathrm{O}$ & $\mathrm{K}_{2} \mathrm{O}$ \\
\hline \multirow[t]{2}{*}{$50 \mathrm{R}-3,62-67$} & \multirow[t]{2}{*}{ Interst ol ox gabbro I } & 59.23 & 25.16 & 0.408 & 7.20 & 6.78 & 0.144 \\
\hline & & 0.65 & 0.26 & 0.667 & 0.12 & 0.22 & 0.019 \\
\hline \multirow[t]{2}{*}{$51 R-1,94-99$} & \multirow[t]{2}{*}{ Interst ol ox gabbro I } & 59.32 & 25.28 & 0.190 & 7.56 & 6.63 & 0.161 \\
\hline & & 0.68 & 0.06 & 0.075 & 0.14 & 0.42 & 0.025 \\
\hline 51R-1, 99-103 & Interst ol ox gabbro 1 & 60.02 & 25.50 & 0.229 & 7.38 & 6.80 & 0.138 \\
\hline & & 0.32 & 0.16 & 0.108 & 0.17 & 0.11 & 0.016 \\
\hline $52 \mathrm{R}-3,121-123$ & Interst ol ox gabbro I & 59.71 & 25.60 & 0.134 & 7.51 & 7.15 & 0.094 \\
\hline & & 0.41 & 0.17 & 0.043 & 0.10 & 0.13 & 0.034 \\
\hline $52 \mathrm{R}-4,88-94$ & Interst ol ox gabbro I & 60.25 & 25.16 & 0.262 & 7.01 & 7.03 & 0.101 \\
\hline & & 0.43 & 0.36 & 0.166 & 0.39 & 0.20 & 0.053 \\
\hline $53 \mathrm{R}-1,47-54$ & Interst ol ox gabbro I & 61.16 & 24.98 & 0.166 & 6.71 & 7.06 & 0.143 \\
\hline & & 0.38 & 0.31 & 0.055 & 0.39 & 0.37 & 0.030 \\
\hline $53 \mathrm{R}-1,123-127$ & Interst ol ox gabbro 1 & 60.67 & 24.96 & 0.166 & 6.63 & 7.13 & 0.133 \\
\hline & & 0.44 & 0.27 & 0.093 & 0.34 & 0.19 & 0.034 \\
\hline $53 \mathrm{R}-2,31-39$ & Interst ol ox gabbro I & 59.56 & 24.89 & 0.286 & 6.71 & 7.29 & 0.115 \\
\hline & & 0.69 & 0.35 & 0.269 & 0.25 & 0.23 & 0.041 \\
\hline $54 R-5,117-119$ & Interst ol ox gabbro 1 & 59.35 & 25.37 & 0.180 & 7.59 & 6.82 & 0.113 \\
\hline & & 0.45 & 0.53 & 0.047 & 0.39 & 0.16 & 0.037 \\
\hline 55R-2, 101-105 & Interst ol ox gabbro I & 59.91 & 25.12 & 0.173 & 7.08 & 7.14 & 0.143 \\
\hline & & 0.60 & 0.40 & 0.072 & 0.43 & 0.30 & 0.041 \\
\hline $82 R-6,73-78$ & Interst ol ox gabbro I & 59.82 & 25.31 & 0.154 & 7.25 & 6.89 & 0.124 \\
\hline & & 0.59 & 0.38 & 0.052 & 0.35 & 0.26 & 0.026 \\
\hline $34 \mathrm{R}-4,8-12$ & Interst ol ox gabbro II & 58.41 & 26.16 & 0.272 & 8.41 & 6.19 & 0.109 \\
\hline & & 0.67 & 0.34 & 0.101 & 0.33 & 0.36 & 0.040 \\
\hline $47 R-3,56-61$ & Interst ol ox gabbro II & 59.13 & 25.74 & 0.243 & 7.75 & 6.66 & 0.134 \\
\hline & & 0.35 & 0.26 & 0.207 & 0.24 & 0.22 & 0.018 \\
\hline $49 \mathrm{R}-2,94-100$ & Interst ol ox gabbro II & 59.15 & 25.70 & 0.291 & 7.58 & 6.74 & 0.153 \\
\hline & & 0.66 & 0.44 & 0.185 & 0.45 & 0.26 & 0.027 \\
\hline $52 \mathrm{R}-1,91-100$ & Interst ol ox gabbro II & 58.98 & 25.79 & 0.244 & 7.54 & 7.17 & 0.110 \\
\hline & & 0.46 & 0.49 & 0.139 & 0.39 & 0.33 & 0.075 \\
\hline $54 \mathrm{R}-1,131-136$ & Olivine oxide gabbro & 60.92 & 24.15 & 0.281 & 6.08 & 7.47 & 0.191 \\
\hline & & 0.55 & 0.29 & 0.176 & 0.23 & 0.15 & 0.081 \\
\hline $54 \mathrm{R}-3,20-24$ & Olivine oxide gabbro & 61.67 & 24.38 & 0.181 & 5.94 & 7.46 & 0.240 \\
\hline & & 0.87 & 0.44 & 0.094 & 0.53 & 0.27 & 0.043 \\
\hline $54 \mathrm{R}-3,125-127$ & Olivine oxide gabbro & 59.80 & 24.65 & 0.242 & 6.55 & 7.36 & 0.098 \\
\hline & & 0.64 & 0.31 & 0.111 & 0.38 & 0.28 & 0.044 \\
\hline $55 \mathrm{R}-2,110-120$ & Olivine oxide gabbro & 60.27 & 24.98 & 0.162 & 6.71 & 7.28 & 0.169 \\
\hline & & 0.22 & 0.07 & 0.039 & 0.31 & 0.25 & 0.019 \\
\hline $55 \mathrm{R}-3,83-86$ & Olivine oxide gabbro & 59.94 & 25.27 & 0.187 & 7.07 & 7.08 & 0.137 \\
\hline & & 0.27 & 0.20 & 0.064 & 0.13 & 0.14 & 0.045 \\
\hline $56 \mathrm{R}-2,11-14$ & Olivine oxide gabbro & 62.25 & 24.48 & 0.227 & 6.12 & 7.68 & 0.115 \\
\hline & & 0.44 & 0.19 & 0.126 & 0.16 & 0.20 & 0.065 \\
\hline $56 \mathrm{R}-2,49-52$ & Olivine oxide gabbro & 60.71 & 24.56 & 0.225 & 6.22 & 7.36 & 0.141 \\
\hline & & 0.31 & 0.28 & 0.050 & 0.43 & 0.27 & 0.055 \\
\hline $80 \mathrm{R}-3,67-71$ & Olivine oxide gabbro & 61.07 & 24.33 & 0.169 & 6.36 & 7.30 & 0.185 \\
\hline & & 0.35 & 0.32 & 0.041 & 0.19 & 0.25 & 0.038 \\
\hline $80 \mathrm{R}-6,130-135$ & Olivine oxide gabbro & 61.08 & 24.31 & 0.229 & 5.92 & 7.69 & 0.181 \\
\hline & & 0.36 & 0.16 & 0.051 & 3.27 & 0.24 & 0.019 \\
\hline $86 \mathrm{R}-4,123-130$ & Olivine oxide gabbro & 59.63 & 25.25 & 0.261 & 7.31 & 7.06 & 0.171 \\
\hline & & 0.21 & 0.23 & 0.217 & 0.28 & 0.23 & 0.037 \\
\hline $48 R-2,109-113$ & Ol oxide microgabbro & 59.86 & 25.61 & 0.182 & 7.58 & 6.67 & 0.103 \\
\hline & & 0.37 & 0.36 & 0.054 & 0.30 & 0.72 & 0.037 \\
\hline $80 \mathrm{R}-7,10-18$ & Ol oxide microgabbro & 59.83 & 25.15 & 0.185 & 7.03 & 7.43 & 0.115 \\
\hline & & 0.25 & 0.27 & 0.091 & 0.25 & 0.25 & 0.036 \\
\hline $80 \mathrm{R}-7,23-25$ & Ol oxide microgabbro & 59.33 & 25.14 & 0.140 & 7.36 & 6.97 & 0.083 \\
\hline & & 0.51 & 0.15 & 0.054 & 0.25 & 0.29 & 0.025 \\
\hline $83 \mathrm{R}-7,77-81$ & Troctolite & 50.77 & 31.70 & 0.106 & 14.66 & 3.06 & 0.027 \\
\hline & & 1.06 & 0.70 & 0.044 & 0.93 & 0.44 & 0.009 \\
\hline $83 \mathrm{R}-2,3-9$ & Troctolite & 52.02 & 30.74 & 0.073 & 13.29 & 3.68 & 0.025 \\
\hline & & 0.86 & 0.51 & 0.048 & 0.54 & 0.37 & 0.017 \\
\hline $79 \mathrm{R}-7,99-102$ & Troctolite & 51.05 & 30.77 & 0.131 & 13.75 & 3.47 & 0.027 \\
\hline & & 0.87 & 0.46 & 0.125 & 0.60 & 0.42 & 0.011 \\
\hline $80 \mathrm{R}-1,41-45$ & Troctolite-Ol gabbro & 51.63 & 30.58 & 0.126 & 13.60 & 3.50 & 0.042 \\
\hline & & 1.20 & 0.92 & 0.073 & 0.91 & 0.46 & 0.021 \\
\hline $73 R-3,73-75$ & Vermic cpx ol gabbro & 52.14 & 30.09 & 0.191 & 13.36 & 3.71 & 0.038 \\
\hline & & 1.41 & 1.02 & 0.052 & 1.11 & 0.60 & 0.016 \\
\hline $81 \mathrm{R}-5,1-7$ & Vermic cpx ol gabbro & 52.39 & 30.19 & 0.173 & 12.91 & 3.93 & 0.042 \\
\hline & & 1.15 & 0.61 & 0.120 & 0.73 & 0.56 & 0.024 \\
\hline $71 \mathrm{R}-2,82-84$ & Vermic cpx ol gabbro & 53.33 & 29.03 & 0.236 & 11.99 & 4.59 & 0.072 \\
\hline & & 0.73 & 0.59 & 0.55 & 0.58 & 0.29 & 0.019 \\
\hline $81 R-7,64-66$ & Vermic cpx ol gabbro & 52.77 & 29.53 & 0.090 & 12.22 & 4.40 & 0.026 \\
\hline & & 0.63 & 0.60 & 0.035 & 0.58 & 0.35 & 0.007 \\
\hline $62 \mathrm{R}-4,21-24$ & Olivine gabbro & 53.64 & 21.90 & 0.285 & 12.56 & 4.15 & 0.057 \\
\hline & & 0.98 & 0.77 & 0.042 & 0.87 & 0.54 & 0.011 \\
\hline
\end{tabular}


Table 4 (continued).

\begin{tabular}{llrrrrrr}
\hline \multirow{2}{*}{$\begin{array}{c}\text { Core, section, } \\
\text { interval (cm) }\end{array}$} & Rock type & $\mathrm{SiO}_{2}$ & $\mathrm{Al}_{2} \mathrm{O}_{3}$ & $\mathrm{Fe}_{2} \mathrm{O}_{3}$ & $\mathrm{CaO}$ & $\mathrm{Na}_{2} \mathrm{O}$ & $\mathrm{K}_{2} \mathrm{O}$ \\
\hline 72R-5, 123-125 & Olivine gabbro & 52.42 & 30.06 & 0.240 & 12.49 & 4.16 & 0.056 \\
& & 0.23 & 0.09 & 0.051 & 0.22 & 0.07 & 0.009 \\
$59 \mathrm{R}-4,29-35$ & Olivine gabbro & 54.29 & 29.27 & 0.306 & 11.98 & 4.59 & 0.074 \\
& & 1.32 & 0.80 & 0.077 & 0.98 & 0.52 & 0.029 \\
8D-1, 45-48 & Olivine gabbro & 53.27 & 29.73 & 0.138 & 12.38 & 4.32 & 0.023 \\
& & 0.55 & 0.33 & 0.081 & 0.39 & 0.23 & 0.024 \\
22R-3, 118-120 & Olivine gabbro & 53.54 & 29.02 & 0.137 & 11.78 & 4.47 & 0.030 \\
& & 0.62 & 0.36 & 0.049 & 0.47 & 0.31 & 0.017 \\
21R-2, 49-51 & Olivine gabbro & 53.70 & 28.74 & 0.123 & 11.56 & 4.46 & 0.029 \\
& & 0.13 & 0.18 & 0.050 & 0.11 & 0.32 & 0.025 \\
$60 \mathrm{R}-1,18-20$ & Olivine gabbro & 53.64 & 28.79 & 0.306 & 11.72 & 4.67 & 0.059 \\
& & 0.92 & 0.70 & 0.087 & 0.72 & 0.42 & 0.020 \\
31R-2, 120-122 & Olivine gabbro & 54.32 & 29.02 & 0.126 & 11.51 & 4.63 & 0.043 \\
& & 0.39 & 0.35 & 0.035 & 0.50 & 0.31 & 0.023 \\
59R-3, 70-72 & Olivine gabbro & 55.00 & 28.70 & 0.281 & 11.15 & 4.79 & 0.064 \\
& & 0.38 & 0.32 & 0.090 & 0.29 & 0.21 & 0.014 \\
\hline
\end{tabular}

Note: Standard deviations are also shown below the average of oxide weight percent. Abbreviations are the same as in Table 3.

oxide gabbros contains abundant iron, which exsolved as iron oxide during cooling. This is reflected in the plagioclase analyses; in spite of erratic FeO content (because the EPMA analyses were made with a focused beam), it increases as the An content decreases. The $\mathrm{K}_{2} \mathrm{O}$ content in plagioclase increases from $0.02 \mathrm{wt} \%$ to $0.2 \mathrm{wt} \%$ as An content decreases (Fig. 9).

\section{Olivine}

The $\mathrm{MnO}$ content in olivine steadily increases as a linear function of Fo mol\% (Fig. 10B), from $0.2 \mathrm{wt} \%$ in troctolites to $1.4 \mathrm{wt} \%$ in olivine Fe-Ti oxide gabbros. The $\mathrm{MnO}$ variation is quite similar to that in pyroxenes. The $\mathrm{NiO}$ content decreases exponentially as Fo content decreases (Fig. 10A), from 0.2 wt\% in troctolites to less than 0.04 wt\% in all the Fe-Ti oxide gabbros. The variation is due to the fractionation of olivine into which $\mathrm{Ni}$ is strongly partitioned compared to silicate melt.

\section{Amphibole}

Reddish brown to pale brown amphibole is always present as a minor phase occurring in interstitial areas with $\mathrm{Fe}-\mathrm{Ti}$ oxides or as inclusions in clinopyroxene. It shows the chemical variations consistent with other silicate phases. This fact and the difference in its mode of occurrence from obviously metamorphic amphiboles suggest that amphibole is magmatic.

The $\mathrm{TiO}_{2}$ contents of amphiboles show the same variation pattern as in pyroxenes; as $\mathrm{Mg \#}$ of amphibole decreases, it first increases from troctolite $(1 \mathrm{wt} \%)$ to gabbronorite $(2-4$ wt\%) and reaches a maximum (up to $5 \mathrm{wt} \%$ ) for pigeonite gabbro or interstitial olivine-bearing $\mathrm{Fe}-\mathrm{Ti}$ oxide gabbro, followed by a rapid decrease in olivine $\mathrm{Fe}$ - $\mathrm{Ti}$ oxide gabbro (4-1 wt\%). The $\mathrm{K}_{2} \mathrm{O}$ content of amphibole tends to increase very slightly as the $\mathrm{Mg} \#$ decreases. It reaches a maximum in pigeonite gabbros and interstitial olivine bearing gabbros $(0.5-1 \mathrm{wt} \%)$ and decreases slightly in olivine Fe-Ti oxide gabbros. The $\mathrm{Na}_{2} \mathrm{O}$ contents in amphiboles increase as $\mathrm{Mg \# s}$ decrease, and is highest in pigeonite gabbros. The $\mathrm{Cr}_{2} \mathrm{O}_{3}$ contents of amphiboles decrease exponentially with decreasing $\mathrm{Mg} \#$, from $2 \mathrm{wt} \%$ in troctolites to less than $0.1 \mathrm{wt} \%$ in $\mathrm{Fe}-\mathrm{Ti}$ oxide gabbros. $\mathrm{MnO}$ contents in amphiboles increase steadily as $\mathrm{Mg} \#$ s decrease down to $0.4 \mathrm{wt} \%$ in olivine $\mathrm{Fe}-\mathrm{Ti}$ oxide gabbros. $\mathrm{Al}_{2} \mathrm{O}_{3}$ contents in amphiboles decrease with decreasing $\mathrm{Mg} \#$.

\section{Ilmenite}

The $\mathrm{MgO}$ content of ilmenite in $\mathrm{Fe}$ - $\mathrm{Ti}$ oxide gabbros tends to decrease from $2-3 \mathrm{wt} \%$ in disseminated Fe-Ti oxide olivine gabbros and olivine gabbronorites to less than $1 \mathrm{wt} \%$ in olivine $\mathrm{Fe}-\mathrm{Ti}$ oxide gabbros as the $\mathrm{Mg} \#$ of mafic minerals and $\mathrm{An}$ content of plagioclase decrease.

\section{RELATIONSHIPS BETWEEN FE-TI OXIDE AND OLIVINE GABBROS}

In Hole 735B, Fe-Ti oxide gabbros are commonly found adjacent to and cross-cutting olivine gabbros with sharp contacts between the two (PI. 3, Figs. 1 and 2). These contacts are marked by abrupt changes in modal mineralogy including the appearance of $\mathrm{Fe}$ - $\mathrm{Ti}$ oxides in the $\mathrm{Fe}-\mathrm{Ti}$ oxide gabbro, changes in clinopyroxene morphology, and changes in mineral chemistry (Pl. 3).

Fe-Ti oxide gabbros tend to be more deformed more than the olivine gabbros, possibly because of the presence of abundant Fe-Ti oxides which are more easily deformed than the silicates. For example, centimeter-thick bands of $\mathrm{Fe}-\mathrm{Ti}$ oxide gabbro are porphyroclastic or mylonitic, whereas the host olivine gabbro shows only minor deformation marked by the presence of wavy extinction in plagioclase and kink bands in olivine. In one such sample, element concentration maps indicate a sharp contact that has not been affected by plastic deformation at all, clearly indicating that deformation took place after the two gabbros were juxtaposed by a magmatic process.

The contacts are generally gently inclined or horizontal, but vertical or steeply dipping contacts are also present. (e.g., Sample 118-735B-82R-3, 0-9 cm). About 1-cm to 1-mm thick veins of Fe-Ti oxide gabbro are observed locally to branch out from thicker Fe-Ti oxide gabbros (e.g., Samples 118-735B$82 \mathrm{R}-3,0-9 \mathrm{~cm}$ and $47 \mathrm{R}-3,143-149 \mathrm{~cm}$ ). Map analyses of these boundaries indicate that $\mathrm{Mg \# s}$ of mafic minerals and An content in plagioclase show marked variations within the host olivine gabbro, whereas they are fairly homogeneous in the Fe-Ti oxide gabbro. Across the contacts, there are very steep gradients in chemical plagioclase composition which occur within a few mm of the contacts, (Fig. 11) but more gradual gradients in the $\mathrm{Mg \#}$ of mafic phases which occur over a distance of several centimeters. Similar gradients in mineral compositions have been observed across contacts in other gabbros from the Southwest Indian Ridge by Meyer et al. 
Table 5. Average chemical composition of clinopyroxene in gabbros from Hole 735B.

\begin{tabular}{|c|c|c|c|c|c|c|c|c|c|c|c|c|c|}
\hline \multirow{2}{*}{$\begin{array}{l}\text { Core, section, } \\
\text { interval }(\mathrm{cm})\end{array}$} & \multirow[b]{2}{*}{ Rock type } & \multicolumn{12}{|c|}{ Clinopyroxene } \\
\hline & & $\mathrm{SiO}_{2}$ & $\mathrm{Al}_{2} \mathrm{O}_{3}$ & $\mathrm{TiO}_{2}$ & $\mathrm{FeO}$ & $\mathrm{MnO}$ & $\mathrm{MgO}$ & $\mathrm{CaO}$ & $\mathrm{Na}_{2} \mathrm{O}$ & $\mathrm{Cr}_{2} \mathrm{O}_{3}$ & Wo & En & Fs \\
\hline \multicolumn{14}{|l|}{$118-735 \mathrm{~B}-$} \\
\hline \multirow[t]{2}{*}{$37 \mathrm{R}-3,80-82$} & Ol pigeonite gabbro & 51.20 & 1.922 & 0.604 & 10.88 & 0.352 & 13.29 & 20.20 & 0.428 & 0.006 & 0.428 & 0.392 & 0.180 \\
\hline & & 0.41 & 0.308 & 0.121 & 0.74 & 0.025 & 0.15 & 0.66 & 0.039 & 0.08 & 0.014 & 0.003 & 0.012 \\
\hline $38 \mathrm{R}-3,85-88$ & Ol pigeonite gabbro & 50.44 & 1.900 & 0.666 & 11.29 & 0.317 & 13.62 & 20.00 & 0.443 & 0.000 & 0.419 & 0.397 & 0.184 \\
\hline & & 0.37 & 0.389 & 0.227 & 0.88 & 0.071 & 0.11 & 0.70 & & 0.001 & 0.013 & 0.003 & 0.014 \\
\hline $38 R-4,24-28$ & Ol pigeonite gabbro & 52.27 & 1.717 & 0.514 & 10.51 & 0.304 & 14.09 & 20.11 & 0.393 & 0.005 & 0.420 & 0.409 & 0.171 \\
\hline & & 0.32 & 0.121 & 0.083 & 0.99 & & 0.36 & 1.37 & & 0.012 & 0.027 & 0.013 & 0.017 \\
\hline $45 \mathrm{R}-1,5-12$ & OI pigeonite gabbro & 51.69 & 2.127 & 0.773 & 12.03 & 0.426 & 13.86 & 18.51 & 0.384 & 0.009 & 0.393 & 0.409 & 0.199 \\
\hline & & 0.45 & 0.417 & 0.151 & 1.15 & 0.022 & 0.91 & 1.48 & 0.096 & 0.016 & 0.037 & 0.021 & 0.016 \\
\hline $21 \mathrm{R}-2,27-32$ & Pigeonite gabbro & 52.75 & 2.294 & 0.779 & 10.08 & 0.353 & 13.26 & 20.72 & 0.620 & 0.007 & 0.441 & 0.392 & 0.167 \\
\hline & & 0.06 & 0.141 & 0.121 & 0.34 & 0.04 & 0.31 & 0.52 & 0.026 & 0.012 & 0.011 & 0.010 & 0.005 \\
\hline $23 \mathrm{R}-3,34-37$ & Pigeonite gabbro & 51.80 & 2.185 & 0.721 & 10.24 & 0.341 & 13.43 & 20.42 & 0.541 & 0.007 & 0.434 & 0.397 & 0.170 \\
\hline & & 0.27 & 0.151 & 0.051 & 0.39 & 0.058 & 0.25 & 0.78 & 0.054 & 0.007 & 0.014 & 0.009 & 0.007 \\
\hline $24 \mathrm{R}-2,120-126$ & Pigeonite gabbro & 51.75 & 2.236 & 0.886 & 10.31 & 0.33 & 13.16 & 20.55 & 0.551 & 0.033 & 0.438 & 0.390 & 0.172 \\
\hline & & 0.21 & 0.254 & 0.057 & 0.54 & 0.005 & 0.16 & 0.24 & 0.060 & 0.039 & 0.009 & 0.002 & 0.008 \\
\hline 28R-1, 109-114 & Pigeonite gabbro & 51.87 & 1.838 & 0.752 & 11.14 & 0.418 & 12.91 & 20.42 & 0.520 & 0.030 & 0.434 & 0.382 & 0.185 \\
\hline & & 0.13 & 0.063 & 0.115 & 0.33 & 0.012 & 0.15 & 0.07 & 0.058 & 0.008 & 0.003 & 0.000 & 0.003 \\
\hline $28 \mathrm{R}-3,72-77$ & Pigeonite gabbro & 52.35 & 1.717 & 0.659 & 10.56 & 0.339 & 13.16 & 20.33 & 0.531 & 0.030 & 0.434 & 0.391 & 0.176 \\
\hline & & 0.00 & 0.000 & 0.000 & 0.00 & 0 & 0.00 & 0.00 & 0.000 & 0.00 & 0.000 & 0.000 & 0.000 \\
\hline $44 R-2,16-24$ & Pigeonite gabbro & 51.19 & 2.068 & 0.846 & 10.90 & 0.361 & 12.78 & 20.27 & 0.556 & 0.001 & 0.435 & 0.3 & 0.183 \\
\hline & & 0.18 & 0.112 & 0.128 & 0.33 & 0.011 & 0.23 & 0.43 & 0.052 & 0.002 & 0.005 & 0.001 & 0.006 \\
\hline $46 \mathrm{R}-4,109-113$ & Pigeonite gabbro & 51.94 & 2.335 & 0.794 & 10.32 & 0.35 & 13.23 & 19.94 & 0.571 & 0.015 & 0.430 & 0.397 & 0.174 \\
\hline & & 0.27 & 0.023 & 0.141 & 0.97 & 0.031 & 0.07 & 0.13 & 0.016 & 0.021 & 0.008 & 0.007 & 0.014 \\
\hline 14R-1, 93-97 & Interst ol ox gabbro I & 51.75 & 2.272 & 0.677 & 10.36 & 0.317 & 13.24 & 21.01 & 0.423 & 0.017 & 0.442 & 0.388 & 0.170 \\
\hline & & 0.3 & 0.159 & 0.082 & 0.59 & 0.0 & 0.22 & 0.51 & & & 0.0 & & 0.010 \\
\hline $2 \mathrm{IR}-1,82-89 \mathrm{CT}$ & Interst ol ox gabbro I & 51.90 & 2.172 & 0.705 & 10.32 & 0.334 & 13.45 & 20.39 & 0.534 & 0.011 & 0.432 & 0.3 & 0.171 \\
\hline & & 0.11 & 0.046 & 0.045 & 0.56 & 0.044 & 0.06 & 0.096 & 0.053 & 0.0 & 0.014 & 0.007 & 0.010 \\
\hline $47 \mathrm{R}-2,117-127$ & Interst ol ox gabbro I & 51.40 & 2.400 & 0.902 & 9.80 & 0.318 & 13.51 & 19.95 & 0.559 & 0.004 & 0.430 & 0.405 & 0.165 \\
\hline & & 0.23 & 0.111 & 0.057 & 0.86 & 0.023 & 0.37 & 0.40 & 0.051 & 0.009 & 0.012 & 0.011 & 0.013 \\
\hline 47R-3, 143-149 CT & Interst ol ox gabbro I & 51.85 & 2.185 & 0.708 & 10.92 & 0.305 & 13.45 & 19.98 & 0.509 & 0.004 & 0.423 & 0.3 & 0.181 \\
\hline & & 0.13 & 0.228 & 0.109 & 0.53 & 0.029 & 0.31 & 0.57 & 0.077 & 0.006 & 0.013 & 0.008 & 0.009 \\
\hline $48 R-2,56-65$ & Interst ol ox gabbro I & 52.08 & 2.112 & 0.746 & 11.73 & 0.354 & 13.30 & 20.07 & 0.444 & 0.013 & 0.420 & 0.388 & 0.192 \\
\hline & & 0.02 & 0.009 & 0.011 & 0.63 & 0.011 & 0.18 & 0.88 & 0.017 & 0.018 & 0.017 & 0.006 & 0.011 \\
\hline $48 \mathrm{R}-3,112-116$ & Interst ol ox gabbro I & 51.78 & 2.011 & 0.669 & 11.18 & 0.337 & 13.16 & 20.06 & 0.457 & 0.03 & 0.426 & 0.3 & 0.185 \\
\hline & & 0.06 & 0.263 & 0.117 & 0.54 & 0.05 & 0.06 & 0.36 & 0.065 & 0.0 & 0.008 & 0.003 & 0.008 \\
\hline $48 R-4,82-84$ & Interst ol ox gabbro I & 51.25 & 1.955 & 0.633 & 11.00 & 0.33 & 12.77 & 20.01 & 0.421 & 0.014 & 0.432 & 0.383 & 0.185 \\
\hline & & 0.25 & 0.184 & 0.069 & 0.74 & 0.056 & 0.71 & 0.75 & 0.068 & 0.015 & 0.023 & 0.016 & 0.009 \\
\hline $12 \mathrm{R}-1,45-47$ & Gabbronorite & 52.29 & 1.682 & 0.457 & 10.70 & 0.314 & 13.32 & 21.04 & 0.350 & 0.010 & 0.439 & 0.387 & 0.174 \\
\hline & & 0.24 & 0.2 & 0.0 & 0.5 & & 0.21 & & 61 & & & & 0.008 \\
\hline $19 \mathrm{R}-5,47-50$ & Gabbronorite & 52.43 & 1.699 & 0.500 & 8.97 & 0.258 & 14.05 & 21.57 & 0.382 & 0.03 & 0.448 & 0.406 & 0.146 \\
\hline & & 0.43 & 0.189 & 0.118 & 0.34 & 0.03 & 0.20 & 0.42 & 0.039 & 0.03 & 0.005 & 0.0 & 0.007 \\
\hline $19 \mathrm{R}-5,47-50$ & Gabbronorite & 51.95 & 1.820 & 0.492 & 11.14 & 0.358 & 13.23 & 20.07 & 0.412 & 0.0 & 0.425 & 0.390 & 0.184 \\
\hline & & 0.38 & 0.249 & 0.119 & 0.92 & 0.058 & 0.59 & 1.38 & 0.039 & 0.0 & 0.027 & 0.0 & 0.017 \\
\hline $19 \mathrm{R}-5,55-60$ & Gabbronorite & 52.85 & 2.124 & 0.667 & 9.02 & 0.245 & 14.02 & 21.05 & 0.417 & 0.0 & 0.442 & 0.4 & 0.148 \\
\hline & & 0.54 & 0.603 & 0.173 & 1.05 & 0.108 & 0.21 & 0.78 & 0.067 & 0.0 & 0.014 & 0.0 & 0.018 \\
\hline $74 R-6,27-35$ & Gabbronorite & 52.04 & 1.965 & 0.726 & 10.48 & 0.37 & 13.49 & 20.74 & 0.435 & 0.0 & 0.435 & 0.3 & 0.1 \\
\hline & & 0.36 & 0.207 & 0.088 & 0.26 & 0.052 & 0.33 & 0.21 & & & & & 0.0 \\
\hline $76 \mathrm{R}-4,12-19$ & Gabbronorite & 51.02 & 2.281 & 0.693 & 10.06 & 0.32 & 14.12 & 20.21 & 0.476 & 0.02 & 0.424 & 0.4 & 0.165 \\
\hline & & 0.25 & 0.147 & 0.068 & 0.61 & 0.029 & 0.33 & 0.66 & 0.036 & 0.030 & 0.015 & 0.008 & 0.009 \\
\hline $40 \mathrm{R}-5,0-4$ & Olivine gabbronorite & 51.65 & 2.304 & 0.758 & 9.18 & 0.281 & 14.34 & 20.27 & 0.401 & 0.026 & 0.428 & 0.421 & 0.151 \\
\hline & & 0.12 & 0.2 & 0.1 & & & 0.28 & 04 & & & & & 0.014 \\
\hline $43 R-3,95-102$ & Olivine gabbronorite & 51.54 & 2.119 & 0.726 & 10.25 & 0.30 & 14.25 & 19.48 & 0.391 & 0.0 & 0.4 & 419 & 0.169 \\
\hline & & 0.39 & 0.208 & 0.065 & 0.71 & 0.0 & 0.42 & 1.16 & & & & & 0.012 \\
\hline $76 \mathrm{R}-3,34-41 \mathrm{CT}$ & Olivine gabbronorite & 51.90 & 1.969 & 0.581 & 10.86 & 0.3 & 13.98 & 18.83 & 0.402 & 0.000 & 0.4 & 0.416 & 0.181 \\
\hline & & 0.38 & 0.214 & 0.068 & 1.20 & 0.0 & 0.43 & 1.07 & 0.0 & & & 0.0 & 0.0 \\
\hline $77 \mathrm{R}-2,101-107$ & Olivine gabbronorite & 51.84 & 1.975 & 0.611 & 9.93 & 0.3 & 13.92 & 20.78 & 0.413 & 0.0 & 0.434 & 0.404 & 0.162 \\
\hline & & 0.39 & 0.338 & 0.128 & 0.48 & 0.05 & 0.44 & 0.82 & 0.054 & 0.020 & 0.017 & 0.013 & 0.008 \\
\hline $36 \mathrm{R}-4,5-9$ & Dissem ox ol gabbro & 51.70 & 2.372 & 0.791 & 9.15 & 0.32 & 14.01 & 20.52 & 0.497 & 0.028 & 0.435 & 0.413 & 0.151 \\
\hline & & 0.14 & & & 0.43 & & & & & & & & \\
\hline 37R-3, 71-76 CT & Dissem ox ol gabbro & 52.64 & 1.957 & 0.647 & 10.48 & 0.3 & 14.23 & 19.98 & 0.3 & 0.0 & 0.4 & & 0.170 \\
\hline & & 0.35 & 0.296 & 0.15 & 1.44 & & 0.23 & 1.0 & & & & & \\
\hline $40 \mathrm{R}-5,4-8$ & Dissem ox ol gabbro & 51.67 & 2.212 & 0.752 & 10.17 & & 14.49 & 19.28 & 0.3 & $0 .($ & 0.407 & 0.426 & 0.168 \\
\hline & & 0.16 & 0.098 & 0.052 & 0.9 & & 0.44 & 1.38 & & & & & \\
\hline $43 R-4,64-66$ & Dissem ox ol gabbro & 51.67 & 2.300 & 0.714 & 9.72 & 0.3 & 14.12 & 20.50 & 0.440 & & 0.4 & & 0.159 \\
\hline & & 0.44 & 0.209 & 0.067 & 0.85 & & 0.23 & 0.66 & & & & & \\
\hline $46 R-3,121-128$ & Dissem ox ol gabbro & 51.80 & 2.347 & 0.836 & 10.69 & 0.34 & 13.46 & 19.66 & 0.5 & 0.0 & 0.421 & 0.401 & 0.179 \\
\hline & & & & 0.046 & 0.85 & & 0.55 & & & & & & \\
\hline $77 R-2,5-8$ & Dissem ox ol gabbro & 52.03 & 2.238 & 0.707 & 9.49 & 0.286 & 14.38 & 20.10 & 0.397 & 0.032 & 0.423 & 0.421 & 0.156 \\
\hline & & 0.46 & 0.325 & 0.200 & 0.67 & 0.02 & 0.25 & 1.00 & 0.020 & 0.049 & 0.019 & 0.009 & 0.012 \\
\hline $20 \mathrm{R}-1,111-114$ & Ol pigeonite gabbro & 52.27 & 1.897 & 0.625 & 10.96 & 0.372 & 13.70 & 19.75 & 0.424 & 0.031 & 0.417 & 0.402 & 0.181 \\
\hline & & & & & & & & & & & & & \\
\hline 37R-3, 76-79 & Ol pigeonite gabbro & 52.07 & 2.071 & 0.672 & 10.04 & 0.334 & 13.81 & 20.15 & 0.458 & 0.005 & 0.427 & 0.407 & 0.166 \\
\hline
\end{tabular}


Table 5 (continued).

\begin{tabular}{|c|c|c|c|c|c|c|c|c|c|c|c|c|c|}
\hline \multirow{2}{*}{$\begin{array}{l}\text { Core, section, } \\
\text { interval }(\mathrm{cm})\end{array}$} & \multirow[b]{2}{*}{ Rock type } & \multicolumn{12}{|c|}{ Clinopyroxene } \\
\hline & & $\mathrm{SiO}_{2}$ & $\mathrm{Al}_{2} \mathrm{O}_{3}$ & $\mathrm{TiO}_{2}$ & $\mathrm{FeO}$ & $\mathrm{MnO}$ & $\mathrm{MgO}$ & $\mathrm{CaO}$ & $\mathrm{Na}_{2} \mathrm{O}$ & $\mathrm{Cr}_{2} \mathrm{O}_{3}$ & Wo & En & Fs \\
\hline \multirow[t]{2}{*}{$49 \mathrm{R}-1,42-46$} & Interst ol ox gabbro I & 51.46 & 2.024 & 0.716 & 10.96 & 0.369 & 13.03 & 20.32 & 0.477 & 0.014 & 0.432 & 0.386 & 0.182 \\
\hline & & 0.30 & 0.194 & 0.087 & 0.59 & 0.008 & 0.19 & 0.32 & 0.052 & 0.021 & 0.008 & 0.004 & 0.009 \\
\hline $50 \mathrm{R}-2,43-47$ & Interst ol ox gabbro I & 52.17 & 2.073 & 0.672 & 10.83 & 0.363 & 13.12 & 20.44 & 0.469 & 0.005 & 0.434 & 0.387 & 0.179 \\
\hline & & 0.52 & 0.120 & 0.127 & 0.57 & 0.028 & 0.15 & 0.46 & 0.042 & 0.010 & 0.010 & 0.004 & 0.009 \\
\hline $50 \mathrm{R}-3,62-67$ & Interst ol ox gabbro I & 51.44 & 2.187 & 0.755 & 10.77 & 0.358 & 12.93 & 20.09 & 0.513 & 0.006 & 0.432 & 0.387 & 0.181 \\
\hline & & 0.16 & 0.223 & 0.019 & 0.70 & 0.054 & 0.37 & 0.69 & 0.034 & 0.011 & 0.018 & 0.008 & 0.010 \\
\hline 51R-1, 94-99 & Interst ol ox gabbro I & 51.59 & 2.209 & 0.755 & 11.31 & 0.36 & 13.01 & 20.12 & 0.541 & 0.007 & 0.428 & 0.385 & 0.188 \\
\hline & & 0.33 & 0.189 & 0.111 & 0.57 & 0.036 & 0.17 & 1.00 & 0.039 & 0.010 & 0.018 & 0.008 & 0.011 \\
\hline 51R-1, 99-103 & Interst ol ox gabbro I & 51.69 & 2.265 & 0.838 & 11.17 & 0.34 & 13.07 & 20.28 & 0.502 & 0.009 & 0.430 & 0.385 & 0.185 \\
\hline & & 0.16 & 0.100 & 0.074 & 0.56 & 0.045 & 0.13 & 0.47 & 0.055 & 0.016 & 0.010 & 0.003 & 0.009 \\
\hline $52 \mathrm{R}-3,121-123$ & Interst ol ox gabbro I & 51.73 & 2.061 & 0.723 & 11.20 & 0.337 & 12.95 & 20.63 & 0.436 & 0.007 & 0.435 & 0.380 & 0.185 \\
\hline & & 0.35 & 0.313 & 0.164 & 0.44 & 0.031 & 0.31 & 0.40 & 0.056 & 0.015 & 0.009 & 0.007 & 0.007 \\
\hline $52 \mathrm{R}-4,88-94$ & Interst ol ox gabbro I & 51.39 & 1.826 & 0.667 & 12.60 & 0.412 & 12.25 & 19.95 & 0.437 & 0.003 & 0.426 & 0.364 & 0.210 \\
\hline & & 0.24 & 0.173 & 0.111 & 0.57 & 0.027 & 0.32 & 0.56 & 0.052 & 0.005 & 0.014 & 0.009 & 0.008 \\
\hline $53 R-1,47-54$ & Interst ol ox gabbro I & 51.98 & 1.831 & 0.686 & 12.70 & 0.42 & 12.28 & 20.51 & 0.452 & 0.018 & 0.432 & 0.360 & 0.209 \\
\hline & & 0.27 & 0.206 & 0.084 & 0.56 & 0.068 & 0.19 & 0.61 & 0.047 & 0.021 & 0.011 & 0.007 & 0.008 \\
\hline 53R-1, 123-127 & Interst ol ox gabbro I & 51.58 & 1.766 & 0.697 & 12.63 & 0.424 & 12.16 & 20.00 & 0.415 & 0.017 & 0.428 & 0.362 & 0.211 \\
\hline & & 0.55 & 0.134 & 0.119 & 0.46 & 0.044 & 0.08 & 0.80 & 0.032 & 0.033 & 0.012 & 0.003 & 0.010 \\
\hline 53R-2, 31-39 & Interst ol ox gabbro 1 & 51.15 & 1.796 & 0.704 & 12.41 & 0.433 & 12.26 & 19.80 & 0.470 & 0.026 & 0.425 & 0.366 & 0.208 \\
\hline & & 0.33 & 0.226 & 0.155 & 0.34 & 0.038 & 0.18 & 0.53 & 0.039 & 0.024 & 0.009 & 0.005 & 0.007 \\
\hline $54 \mathrm{R}-5,117-119$ & Interst ol ox gabbro I & 52.04 & 1.801 & 0.617 & 12.10 & 0.371 & 12.83 & 19.55 & 0.421 & 0.006 & 0.417 & 0.381 & 0.202 \\
\hline & & 0.17 & 0.238 & 0.145 & 1.16 & 0.059 & 0.25 & 0.53 & 0.029 & 0.008 & 0.012 & 0.007 & 0.019 \\
\hline $55 \mathrm{R}-2,101-105$ & Interst ol ox gabbro I & 51.47 & 1.424 & 0.454 & 13.93 & 0.44 & 11.84 & 19.24 & 0.440 & 0.012 & 0.413 & 0.354 & 0.233 \\
\hline & & 0.77 & 0.266 & 0.109 & 0.81 & 0.038 & 0.21 & 0.29 & 0.061 & 0.014 & 0.009 & 0.007 & 0.011 \\
\hline $82 R-6,73-78$ & Interst ol ox gabbro I & 52.00 & 2.040 & 0.683 & 10.62 & 0.404 & 13.28 & 20.71 & 0.441 & 0.017 & 0.436 & 0.389 & 0.175 \\
\hline & & 0.46 & 0.206 & 0.082 & 1.00 & 0.032 & 0.056 & 0.42 & 0.052 & 0.035 & 0.012 & 0.012 & 0.016 \\
\hline $34 R-4,8-12$ & Interst ol ox gabbro II & 51.56 & 2.245 & 0.778 & 10.60 & 0.327 & 13.11 & 20.19 & 0.500 & 0.022 & 0.432 & 0.390 & 0.177 \\
\hline & & 0.27 & 0.201 & 0.091 & 0.67 & 0.046 & 0.25 & 0. & & & & & 0.010 \\
\hline $47 \mathrm{R}-3,56-61$ & Interst ol ox gabbro II & 51.72 & 2.317 & 0.835 & 10.43 & 0.355 & 13.19 & 20.65 & 0.531 & 0.006 & 0.438 & 0.389 & 0.173 \\
\hline & & 0.29 & 0.188 & 0.079 & 0.42 & 0.029 & 0.0 & 0.51 & 0.033 & 0.008 & 0.0 & 0.0 & 0.007 \\
\hline $49 \mathrm{R}-2,94-100$ & Interst ol ox gabbro II & 52.35 & 1.772 & 0.540 & 10.68 & 0.352 & 13.84 & 19.92 & 0.420 & 0.0 & 0.4 & 0.4 & 0.176 \\
\hline & & 0.29 & 0.336 & 0.108 & 1.13 & 0.045 & 0.40 & 1.19 & 0.084 & 0.0 & 0.025 & 0.010 & 0.019 \\
\hline $52 \mathrm{R}-1,9 \mathrm{I}-100$ & Interst ol ox gabbro II & 51.34 & 2.169 & 0.781 & 11.22 & 0.358 & 12.94 & 20.23 & 0.535 & 0.025 & 0.431 & 0.383 & 0.186 \\
\hline & & 0.35 & 0.280 & 0.138 & 0.74 & 0.046 & 0.28 & 0.74 & 0.062 & 0.032 & 0.17 & 0.006 & 0.012 \\
\hline $54 \mathrm{R}-1,131-136$ & Olivine oxide gabbro & 50.80 & 1.464 & 0.640 & 14.09 & 0.446 & 10.78 & 19.45 & 0.536 & 0.008 & 0.428 & 0.330 & 0.242 \\
\hline & & 0.19 & 0.043 & 0.049 & 0.45 & 0.011 & 0.20 & & 0.047 & 0.0 & 0.018 & 0.009 & 0.010 \\
\hline $54 \mathrm{R}-3,20-24$ & Olivine oxide gabbro & 51.49 & 1.167 & 0.413 & 15.88 & 0.498 & 10.88 & 19.22 & 0.398 & 0.0 & 0.411 & 0.324 & 0.265 \\
\hline & & 0.11 & 0.189 & 0.093 & 1.50 & 0.051 & 0.52 & 0.72 & 0.027 & 0.0 & 0.0 & 0.015 & 0.025 \\
\hline $54 \mathrm{R}-3,125-127$ & Olivine oxide gabbro & 50.80 & 1.305 & 0.478 & 14.81 & 0.493 & 10.86 & 19.56 & 0.389 & 0.06 & 0.423 & 0.327 & 0.250 \\
\hline & & 0.19 & 0.048 & 0.069 & 0.30 & 0.033 & 0.0 & 0. & 0.027 & 0.009 & 0.0 & 0.0 & 0.005 \\
\hline $55 \mathrm{R}-2,110-120$ & Olivine oxide gabbro & 51.69 & 1.769 & 0.518 & 12.34 & 0.404 & 12.3 & 19.7 & 0.463 & 0.009 & 24 & 0.369 & 0.207 \\
\hline & & 0.14 & 0.466 & 0.121 & 1.58 & 0.067 & 0.75 & 0.39 & 0.030 & 0.0 & 0.005 & 0.0 & 0.026 \\
\hline $55 \mathrm{R}-3,83-86$ & Olivine oxide gabbro & 51.77 & 1.585 & 0.570 & 14.10 & 0.41 & 12.16 & 19.06 & 0.436 & 0.06 & 0.406 & 0.360 & 0.234 \\
\hline & & 0.29 & 0.091 & 0.077 & 1.08 & 0.042 & 0.4 & 1.07 & 0.053 & 0.013 & 0.024 & 0.0 & 0.016 \\
\hline $56 \mathrm{R}-2,11-14$ & Olivine oxide gabbro & 51.66 & 1.447 & 0.504 & 14.49 & 0.455 & 11.4 & 19.02 & 0.484 & 0.011 & 0.411 & 0.344 & 0.244 \\
\hline & & 0.18 & 0.180 & 0.137 & 0.15 & 0.01 & 0.75 & 1. & 0.089 & 0.0 & 0.0 & 0.0 & 0.003 \\
\hline $56 \mathrm{R}-2,49-52$ & Olivine oxide gabbro & 51.53 & 1.445 & 0.493 & 14.49 & 0.50 & 11.47 & 19.24 & 0.489 & & 0.414 & 43 & 0.243 \\
\hline & & 0.2 & 0.02 & 0.06 & 0. & & & & & & & 0.0 & 0.010 \\
\hline $80 \mathrm{R}-3,67-71$ & Olivine oxide gabbro & 51.35 & 1.469 & 0.490 & 13.52 & 0.528 & 11.92 & 20. & 0.423 & & & 51 & 0.223 \\
\hline & & 0.24 & 0.180 & 0.076 & 0.94 & 0.04 & 0.46 & & & & 95 & 0.0 & 0.016 \\
\hline $80 \mathrm{R}-6,130-135$ & Olivine oxide gabbro & 51.46 & 1.330 & 0.519 & 14.60 & 0.573 & 11.47 & 19.52 & 0.470 & 0.00 & 16 & 0.340 & 0.2 \\
\hline & & 0.27 & 0.094 & 0.108 & 1.10 & 0.04 & 0.2 & & & & 0.0 & 0.0 & 0.0 \\
\hline $86 \mathrm{R}-4,123-130$ & Olivine oxide gabbro & 52.09 & 1.743 & 0.413 & 12.40 & 0.397 & 12.49 & 20.20 & 0.485 & 0.000 & 0.427 & 0.368 & 0.2 \\
\hline & & 0.20 & 0.093 & 0.129 & 0.54 & 0.065 & 0.08 & 0.30 & 0.061 & 0.000 & 0.006 & 0.002 & 0.009 \\
\hline $48 \mathrm{R}-2,109-113$ & Ol oxide microgabbro & 51.91 & 1.898 & 0.674 & 12.54 & 0.344 & 13.56 & 18.72 & 0.402 & 0.0 & & & 0.206 \\
\hline & & 0.20 & & & 1.17 & & & & & & & & 0.0 \\
\hline $80 \mathrm{R}-7,10-18$ & Ol oxide microgabbro & 51.41 & 1.546 & 0.502 & 13.46 & 0.441 & 12.00 & 19.8 & 0.458 & 0.0 & & & 0.223 \\
\hline & & 0.44 & 0.200 & 0.113 & 0.63 & 0.06 & 0.1 & 0. & 0.0 & 0.0 & 0.0 & 0.0 & 0.0 \\
\hline $80 \mathrm{R}-7,23-25$ & Ol oxide microgabbro & 50.99 & 1.843 & 0.569 & 12.98 & 0.385 & 12.20 & 19.1 & 0.440 & 0.011 & & 0.3 & 0.2 \\
\hline & & 0.53 & 0.139 & 0.100 & 0.47 & 0.012 & 0.43 & 0.98 & 0.071 & 0.006 & 0.021 & 0.013 & 0.008 \\
\hline $83 R-7,77-81$ & Troctolite & 52.33 & 3.608 & 0.576 & 3.90 & 0.125 & 16.32 & 21.83 & 0.490 & 1.237 & 0.459 & 0.477 & 0.064 \\
\hline & & 0.09 & & & 0.54 & & & & & & & & 0.009 \\
\hline $83 R-2,3-9$ & Troctolite & 52.60 & 3.355 & 0.512 & 4.69 & 0.143 & 16.97 & 20.7 & 0.3 & 0.8 & 0.4 & 0.4 & 0.076 \\
\hline & & & 0.261 & 0.0 & 0.41 & & 1.6 & 1. & 0.0 & 0.3 & 0.0 & 0.0 & 0.0 \\
\hline 79R-7, 99-102 & Troctolite & 51.93 & 3.191 & 1.086 & 4.39 & 0.175 & 15.87 & 22.36 & 0.442 & 0.539 & & & 0.0 \\
\hline & & 0.47 & 0.531 & 0.223 & 0.09 & 0.04 & 0.20 & 0.51 & 0.075 & 0.090 & 0.005 & 0.005 & 0.001 \\
\hline $73 R-3,73-75$ & Vermic cpx ol gabbro & 52.89 & 2.734 & 0.50 & 5.50 & 0.153 & 16.46 & 21.02 & 0.332 & 0.180 & 0.436 & 0.475 & 0.089 \\
\hline & & & & & 0.6 & & 0.93 & 1.4 & & & & & \\
\hline $81 R-5,1-7$ & Vermic cpx ol gabbro & 52.74 & 2.673 & 0.520 & 5.24 & 0.164 & 16.22 & 21.39 & 0.3 & 0.2 & 0.4 & 0.470 & 0.085 \\
\hline & & 0.45 & 0.279 & 0.121 & 0.50 & 0.027 & 0.53 & 1.0 & 0.0 & 0.0 & 0.0 & 0.015 & 0.008 \\
\hline $71 \mathrm{R}-2,82-84$ & Vermic cpx ol gabbro & 52.51 & 2.571 & 0.593 & 6.80 & 0.143 & 16.50 & 19.52 & 0.330 & 0.186 & 0.409 & 0.480 & 0.111 \\
\hline & & 0.41 & 0.255 & 0.2. & 1.14 & 0.037 & 1.9 & 2. & 0.0 & 0.0 & 0.0 & 0.047 & 0.016 \\
\hline $81 \mathrm{R}-7,64-66$ & Vermic cpx ol gabbro & 52.46 & 2.768 & 0.558 & 6.57 & 0.211 & 17.57 & 18.53 & & 0.097 & & 0.508 & 0.106 \\
\hline & & 1.20 & 0.837 & 0.129 & 0.52 & 0.015 & 0.62 & 0.39 & 0.162 & 0.041 & 0.015 & 0.009 & 0.006 \\
\hline
\end{tabular}


Table 5 (continued).

\begin{tabular}{|c|c|c|c|c|c|c|c|c|c|c|c|c|c|}
\hline \multirow{2}{*}{$\begin{array}{l}\text { Core, section, } \\
\text { interval }(\mathrm{cm})\end{array}$} & \multirow[b]{2}{*}{ Rock type } & \multicolumn{12}{|c|}{ Clinopyroxene } \\
\hline & & $\mathrm{SiO}_{2}$ & $\mathrm{Al}_{2} \mathrm{O}_{3}$ & $\mathrm{TiO}_{2}$ & $\mathrm{FeO}$ & $\mathrm{MnO}$ & $\mathrm{MgO}$ & $\mathrm{CaO}$ & $\mathrm{Na}_{2} \mathrm{O}$ & $\mathrm{Cr}_{2} \mathrm{O}_{3}$ & Wo & En & Fs \\
\hline \multirow[t]{2}{*}{$62 \mathrm{R}-4,21-24$} & Olivine gabbro & 52.60 & 2.867 & 0.892 & 6.71 & 0.23 & 16.04 & 20.36 & 0.421 & 0.135 & 0.425 & 0.466 & 0.109 \\
\hline & & 0.34 & 0.349 & 0.151 & 0.60 & 0.073 & 1.04 & 1.37 & 0.056 & 0.080 & 0.030 & 0.025 & 0.011 \\
\hline \multirow{2}{*}{$72 R-5,123-125$} & Olivine gabbro & 53.03 & 2.716 & 0.558 & 5.75 & 0.174 & 16.66 & 20.80 & 0.355 & 0.156 & 0.429 & 0.478 & 0.093 \\
\hline & & 0.33 & 0.146 & 0.058 & 0.36 & 0.025 & 0.44 & 1.05 & 0.037 & 0.037 & 0.020 & 0.014 & 0.006 \\
\hline \multirow{2}{*}{$59 \mathrm{R}-4,29-35$} & Olivine gabbro & 52.50 & 3.300 & 0.636 & 6.42 & 0.18 & 16.31 & 20.33 & 0.400 & 0.231 & 0.424 & 0.472 & 0.104 \\
\hline & & 0.77 & 0.476 & 0.194 & 0.80 & 0.026 & 1.52 & 1.73 & 0.064 & 0.081 & 0.041 & 0.039 & 0.013 \\
\hline \multirow{2}{*}{$8 D-1,45-48$} & Olivine gabbro & 52.45 & 2.964 & 0.542 & 5.17 & 0.174 & 15.63 & 22.36 & 0.359 & 0.253 & 0.465 & 0.452 & 0.084 \\
\hline & & 0.49 & 0.274 & 0.114 & 0.04 & 0.036 & 0.27 & 0.27 & 0.008 & 0.177 & 0.001 & 0.001 & 0.001 \\
\hline \multirow[t]{2}{*}{$22 \mathrm{R}-3,118-120$} & Olivine gabbro & 52.21 & 2.425 & 0.645 & 5.77 & 0.191 & 14.86 & 21.20 & 0.292 & 0.164 & 0.457 & 0.446 & 0.097 \\
\hline & & 0.35 & 0.528 & 0.041 & 0.51 & 0.039 & 0.22 & 1.23 & 0.002 & 0.019 & 0.021 & 0.012 & 0.010 \\
\hline \multirow[t]{2}{*}{ 2IR-2, 49-51 } & Olivine gabbro & 51.71 & 2.727 & 0.649 & 5.73 & 0.184 & 15.48 & 21.20 & 0.319 & 0.070 & 0.449 & 0.456 & 0.095 \\
\hline & & 0.37 & 0.088 & 0.102 & 0.48 & 0.017 & 0.82 & 0.49 & 0.039 & 0.022 & 0.019 & 0.014 & 0.006 \\
\hline \multirow[t]{2}{*}{$60 \mathrm{R}-1,18-20$} & Olivine gabbro & 50.72 & 3.054 & 0.931 & 6.60 & 0.213 & 14.78 & 21.34 & 0.416 & 0.12 & 0.454 & 0.437 & 0.110 \\
\hline & & 0.41 & 0.203 & 0.312 & 0.37 & 0.008 & 1.00 & 0.26 & 0.001 & 0.035 & 0.015 & 0.021 & 0.008 \\
\hline \multirow[t]{2}{*}{$31 \mathrm{R}-2,120-122$} & Olivine gabbro & 52.72 & 2.665 & 0.605 & 6.02 & 0.162 & 16.19 & 20.94 & 0.360 & 0.121 & 0.435 & 0.468 & 0.098 \\
\hline & & 0.44 & 0.145 & 0.169 & 1.00 & 0.023 & 0.51 & 1.04 & 0.038 & 0.038 & 0.021 & 0.016 & 0.016 \\
\hline \multirow[t]{2}{*}{$59 \mathrm{R}-3,70-72$} & Olivine gabbro & 51.79 & 2.962 & 0.830 & 7.46 & 0.225 & 15.00 & 21.04 & 0.451 & 0.108 & 0.441 & 0.437 & 0.122 \\
\hline & & 0.16 & 0.248 & 0.064 & 0.56 & 0.044 & 0.32 & 0.66 & 0.070 & 0.055 & 0.014 & 0.010 & 0.009 \\
\hline
\end{tabular}

Note: Standard deviations are also shown below the average of oxide weight percent. Abbreviations are the same as in Table 3.

(1989) who attributed the steeper plagioclase gradients to very slow diffusion rates in plagioclase. In gabbros from Hole $735 \mathrm{~B}$, different diffusion rates in plagioclase and mafic phases have produced disequilibrium phase assemblages near contacts between gabbro types, e.g., co-existing calcic plagioclase and iron-rich olivine (Fig. 12). Because of this, only analyses of minerals at least $2 \mathrm{~cm}$ from contacts have been used in the downhole mineral plots (Figs. 2, 3) and in mineral co-variation plots (Figs. 4, 5).

Seventeen contacts between $\mathrm{Fe}-\mathrm{Ti}$ oxide gabbro and olivine gabbro have been examined (PI. 3, Figs. 4-6). At the sharpest contact (Sample 118-735B-79R-7, 2-9 cm), an oscillatory zoned calcic plagioclase in an olivine gabbro is sharply cut by a relatively homogeneous sodic plagioclase within an $\mathrm{Fe}-\mathrm{Ti}$ oxide gabbro having an irregularly serrated boundary (PI. 3, Figs. 3 and 4; Figs. 11A and 11B). Under the optical microscope, twin boundaries in the plagioclase can be traced continuously over the boundary, with a slight kinking at the contact because of the compositional difference (PI. 3, Figs. 1-3). These observations suggest that sodic plagioclase grew on the disrupted calcic plagioclase of the olivine gabbro. An overgrowth of iron-rich clinopyroxene on olivine in olivine gabbro was also observed in this sample (Pl. 3, Fig. 4). Consequently, we infer that the melt from which the Fe-Ti oxide gabbro crystallized intruded into either solid or almost solidified olivine gabbro and that the boundaries are intrusive contacts.

In general, minerals in $\mathrm{Fe}-\mathrm{Ti}$ oxide gabbro veins exhibit a wide range in compositions compared to their host olivine gabbros (Fig. 13). Furthermore, there is an inverse relationship between mineral compositions in $\mathrm{Fe}$ - $\mathrm{Ti}$ oxide gabbro veins and mineral compositions in host olivine gabbros (Fig. 13). Thus, the most evolved mineral compositions are found in $\mathrm{Fe}-\mathrm{Ti}$ oxide gabbro veins that intrude the most primitive olivine gabbros. In addition to this complementary relationship, variable chemical exchange between $\mathrm{Fe}$-Ti oxide gabbro veins and host olivine gabbro is indicated by an inverse relationships between delta An content (difference in plagioclase composition in the vein and in the unreacted gabbro host) and the thickness of the reaction zone. The thickness of the reaction zone is determined either by measuring the distance within a single crystal that is zoned away from the contact (diffusion distance in Fig. 14) or by measuring the distance over which multiple plagioclase grains exhibit chemical zoning away from the contact (penetration distance in Fig. 14).
The variation in the diffusion and penetration distance may have been caused by difference in thermal history (temperature or heating duration), chemical contrast between intruded melt and its host, and amounts of trapped melt in the host olivine gabbro. The negative correlation of the diffusion and penetration distance with the difference in the mineral compositions, however, can only be explained by decreases in temperature (or heating duration) and in the abundance of trapped melt as the host olivine gabbro becomes more primitive. There may be some trapped melt in the host olivine gabbro showing large penetration distance at the contact with $\mathrm{Fe}-\mathrm{Ti}$ oxide gabbro, because in such samples plagioclase composition changes along grain boundaries deeply into the olivine gabbro (Pl. 3, Fig. 5; Fig. 11C), which cannot be explained by grain boundary diffusion.

The evolved magma might have intruded into the cumulus pile of olivine gabbro whose lower, more primitive portion was almost solidified, while the relatively evolved upper portion still contained trapped melt. The common occurrence of dikes or sills of evolved $\mathrm{Fe}-\mathrm{Ti}$ oxide gabbro and fairly primitive troctolitic microgabbro from Hole 735B (Robinson, Von Herzen, et al., 1989) suggest that the disruption of solidified or partially solidified lower oceanic crust commonly took place even near mid-oceanic ridge, at least in the region near the fracture zones. The steady downcore increase of the diffusion distance in plagioclase at the contact between olivine and $\mathrm{Fe}$-Ti oxide gabbros suggests that cooling from the base or wall of a magma chamber, which was modeled by Morton and Sleep (1985) assuming a deep hydrothermal cell. The deep hydrothermal activity is substantiated by abundant hydrothermal alteration even at the base of Hole 735B. The close association of the hydrothermal alteration and $\mathrm{Fe}$-Ti oxide gabbros suggest that the fracture system filled by evolved melts was resumed during the subsequent hydrothermal circulation.

\section{ORIGIN OF THE DOWNHOLE MINERALOGICAL VARIATIONS IN THE FE-TI OXIDE GABBROS}

As described above, the Fe-Ti oxide gabbros are characterized by several downhole mineralogical cycles that are marked by decreases in the An content of plagioclase and the $\mathrm{Mg} \#$ of mafic minerals (Figs. 2 and 3). These trends are opposite from those observed among the olivine gabbros and troctolites. Reverse fractionation trends have been reported from the marginal series of the Jimberlana Intrusion (Camp- 
Table 6. Average chemical composition of orthopyroxene in gabbros from Hole 735B.

\begin{tabular}{|c|c|c|c|c|c|c|c|c|c|c|c|c|}
\hline \multirow{2}{*}{$\begin{array}{l}\text { Core, section, } \\
\text { interval }(\mathrm{cm})\end{array}$} & \multirow[b]{2}{*}{ Rock type } & \multicolumn{11}{|c|}{ Orthopyroxene } \\
\hline & & $\mathrm{SiO}_{2}$ & $\mathrm{Al}_{2} \mathrm{O}_{3}$ & $\mathrm{TiO}_{2}$ & $\mathrm{FeO}$ & $\mathrm{MnO}$ & $\mathrm{MgO}$ & $\mathrm{CaO}$ & $\mathrm{Cr}_{2} \mathrm{O}_{3}$ & Wo & En & Fs \\
\hline \multicolumn{13}{|l|}{ 118-735B- } \\
\hline \multirow[t]{2}{*}{$12 \mathrm{R}-1,45-47$} & Gabbronorite & 52.96 & 0.803 & 0.247 & 24.33 & 0.611 & 20.50 & 1.180 & 0.023 & 0.0242 & 0.5857 & 0.3900 \\
\hline & & 0.18 & 0.080 & 0.097 & 1.02 & 0.070 & 0.55 & 0.267 & 0.028 & 0.0055 & 0.0135 & 0.0174 \\
\hline $19 \mathrm{R}-5,47-50$ & Gabbronorite & 52.69 & 0.987 & 0.278 & 22.66 & 0.562 & 21.51 & 1.374 & 0.015 & 0.0280 & 0.6105 & 0.3615 \\
\hline & & 0.60 & 0.198 & 0.068 & 2.13 & 0.117 & 1.39 & 0.390 & 0.015 & 0.0078 & 0.0340 & 0.0376 \\
\hline $19 \mathrm{R}-5,55-60$ & Gabbronorite & 54.26 & 1.126 & 0.336 & 20.37 & 0.490 & 23.32 & 1.297 & 0.010 & 0.0261 & 0.6536 & 0.3203 \\
\hline & & 0.25 & 0.110 & 0.050 & 0.09 & 0.023 & 0.03 & 0.162 & 0.018 & 0.0032 & 0.0026 & 0.0013 \\
\hline $74 \mathrm{R}-6,27-35$ & Gabbronorite & 53.13 & 0.802 & 0.454 & 22.15 & 0.655 & 21.56 & 1.414 & 0.005 & 0.0290 & 0.6159 & 0.3550 \\
\hline & & 0.15 & 0.072 & 0.034 & 0.46 & 0.046 & 0.24 & 0.140 & 0.005 & 0.0028 & 0.0059 & 0.0051 \\
\hline $76 \mathrm{R}-4,12-19$ & Gabbronorite & 52.51 & & 0.346 & & & 22.98 & 1.504 & 0.013 & 0.0299 & 0.6348 & 0.3353 \\
\hline & & 0.29 & 0.121 & 0.064 & 1.05 & 0.041 & 0.32 & 0.439 & 0.017 & 0.0090 & 0.0077 & 0.0134 \\
\hline $40 \mathrm{R}-5,0-4$ & Olivine gabbronorite & 53.25 & 1.020 & 0.362 & 20.86 & 0.556 & 23.09 & 1.437 & 0.007 & 0.0288 & 0.6445 & 0.3267 \\
\hline & & 0.21 & 0.061 & 0.030 & 0.45 & 0.031 & 0.19 & 0.402 & 0.009 & & & 0.0068 \\
\hline $43 \mathrm{R}-3,95-102$ & Olivine gabbronorite & 52.94 & 1.039 & 0.346 & 20.18 & 0.532 & 22.55 & 1.161 & 0.011 & 0.0240 & 0.6500 & 0.3260 \\
\hline & & 0.49 & 0.228 & 0.050 & 1.73 & 0.045 & 0.66 & 0.144 & 0.015 & 0.0027 & 0.0234 & 0.0238 \\
\hline 76R-3, 34-41 CT & Olivine gabbronorite & 52.61 & 1.146 & 0.281 & 21.56 & 0.558 & 21.65 & 1.077 & 0.020 & 0.0224 & 0.6271 & 0.3505 \\
\hline & & 0.17 & 0.083 & 0.033 & 0.23 & 0.009 & 0.02 & 0.225 & 0.011 & 0.0047 & 0.0004 & 0.0043 \\
\hline $77 R-2,101-107$ & Olivine gabbronorite & 52.83 & 1.017 & 0.306 & 21.84 & 0.590 & 22.15 & 1.125 & 0.010 & 0.0230 & 0.6290 & 0.3480 \\
\hline & & 0.24 & 0.064 & 0.028 & 0.59 & 0.045 & 0.55 & 0.188 & 0.012 & 0.0039 & 0.0092 & 0.0107 \\
\hline $36 \mathrm{R}-4,5-9$ & Dissem ox ol gabbro & 53.13 & 1.010 & 0.379 & 21.35 & 0.617 & 22.48 & 1.145 & 0.000 & 0.0233 & 0.6371 & 0.3395 \\
\hline & & 0.34 & 0.2 & 0.1 & 0.07 & 0.0 & 0. & & & & & \\
\hline 37R-3, 71-76 CT & Dissem ox ol gabbro & 53.54 & 0.851 & 0.238 & 23.09 & 0.623 & 22.25 & 1.037 & 0.003 & 0.0207 & 0.6189 & 0.3604 \\
\hline & & 0.13 & 0.082 & 0.075 & 0.13 & 0.029 & 0.09 & 0.037 & 0.004 & 0.0007 & 0.0027 & 0.0020 \\
\hline $40 \mathrm{R}-5,4-8$ & Dissem ox ol gabbro & 52.65 & 1.088 & 0.314 & 22.82 & 0.603 & 21.48 & 1.088 & 0.054 & 0.0223 & 0.6125 & 0.3652 \\
\hline $43 R-4,64-66$ & Dissem ox ol gabbro & 53.47 & 1.017 & 0.323 & 20.75 & 0.524 & 23.12 & 1.424 & 0.006 & 0.0286 & 0.6461 & 0.3253 \\
\hline & 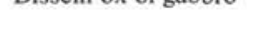 & 0.16 & 0.031 & 0.018 & 0.56 & 0.015 & 0.24 & 0.161 & 0.005 & 0.0032 & 0.0068 & 0.0088 \\
\hline $20 \mathrm{R}-1,111-114$ & Ol pigenoite gabbro & 52.90 & 0.795 & 0.342 & 22.27 & 0.593 & 21.46 & 1.562 & 0.005 & 0.0321 & 0.6118 & 0.3561 \\
\hline & & 0.07 & 0.05 & 0.0 & 0.77 & & & & & & & \\
\hline 37R-3, 76-79 & Ol pigenoite gabbro & 53.38 & 0.743 & 0.175 & 21.50 & 0.593 & 21.87 & 0.868 & & & & 0.3493 \\
\hline & & 0.36 & 0.059 & 0.091 & 0.64 & 0.049 & 1.16 & 0.070 & 0.0 & 0.0018 & 0.0199 & 0.0180 \\
\hline 37R-3, 80-82 & Ol pigenoite gabbro & 51.98 & 0.776 & 0.244 & 23.88 & 0.660 & 20.63 & 0.997 & & 0.0 & & 0.3856 \\
\hline & & 0.21 & 0.104 & 0.063 & 0.44 & 0.056 & 0.40 & 0.106 & 0.0 & 0.0021 & 81 & 0.0084 \\
\hline $38 \mathrm{R}-3,85-88$ & Ol pigenoite gabbro & 51.42 & 0.797 & 0.287 & 25.01 & 0.688 & 20.44 & 1.130 & & 0.0 & 0.5 & 0.3976 \\
\hline & & 0.17 & 0.097 & 0.073 & 0.52 & 0.072 & 0.19 & 0.029 & 0.0 & 0.00 & 71 & 0.0066 \\
\hline $38 R-4,24-28$ & Ol pigenoite gabbro & 53.00 & 0.784 & 0.355 & 22.30 & 0.584 & 21.71 & 1.414 & 0.0 & 0.02 & 0.61 & 0.3551 \\
\hline & & 0.23 & 0.077 & 0.140 & 0.77 & 0.041 & 0.45 & 0.427 & 0.0 & 0.0086 & 0.0064 & 0.0133 \\
\hline $45 \mathrm{R}-1,5-12$ & Ol pigenoite gabbro & 52.65 & 0.855 & 0.314 & 23.30 & 0.657 & 21.07 & 1.615 & 0.024 & 0.0329 & 0.5969 & 0.3702 \\
\hline $21 \mathrm{R}-2,27-32$ & Pigeonite gabbro & 53.57 & 0.773 & 0.226 & 24.06 & 0.742 & 20.70 & 1.267 & 0.014 & 0.0259 & 0.5895 & 0.3846 \\
\hline & & 0.15 & & & 0.4 & & 0.14 & & & & & \\
\hline $23 R-3,34-37$ & Pigeonite gabbro & 53.28 & 0.857 & 0.283 & 21.48 & 0.590 & 22.51 & 1.3 & & & & 0.3392 \\
\hline & & 0.35 & 0.041 & & 0.60 & 0.043 & 0.50 & 0.2 & 0.0 & 0.00 & & 0.0105 \\
\hline $24 \mathrm{R}-2,120-126$ & Pigeonite gabbro & 52.86 & 0.655 & 0.289 & 23.84 & 0.682 & 20. & 1.3 & & 0.02 & 0.58 & 0.3822 \\
\hline & & 0.32 & 0.113 & 0.079 & 1.03 & 0.054 & 0.40 & 0.366 & 0.0 & 0.0077 & 0.01 & 0.0100 \\
\hline $28 \mathrm{R}-1,109-114$ & Pigeonite gabbro & 52.61 & 0.818 & 0.274 & 25.03 & 0.751 & 20.06 & 1.1 & 0.0 & 0.02 & 0.57 & 0.4023 \\
\hline & & 0.26 & 0.060 & 0.021 & 0.04 & 0.002 & 0.06 & 0.1 & 0.0 & 0.00 & 0.0 & 0.0002 \\
\hline 28R-3, 72-77 & Pigeonite gabbro & 52.73 & 0.712 & 0.247 & 25.04 & 0.740 & 19.75 & 1.2 & & 0.02 & & 0.4046 \\
\hline & & 0.31 & 0.063 & & 0.78 & 0.0 & 0.36 & 0.2 & 0.0 & 0.0057 & 0.0 & 0.0111 \\
\hline $44 \mathrm{R}-2,16-24$ & Pigeonite gabbro & 52.21 & 0.695 & 0.302 & 25.19 & 0.73 & 19.47 & 1.2 & & & & 0.4094 \\
\hline & & 0.22 & 0.123 & 0.048 & 1.09 & 0.099 & 0.89 & 0.312 & 0.017 & 0.00 & 0.02 & 0.0185 \\
\hline $46 \mathrm{R}-4,109-113$ & Pigeonite gabbro & 52.45 & 0.974 & 0.321 & 23.22 & 0.635 & 20.49 & 1.167 & 0.013 & & & 0.3793 \\
\hline & & 0.37 & 0.121 & 0.015 & 0.64 & 0.061 & 0.51 & 0.130 & 0.011 & 0.0027 & 0.0118 & 0.0124 \\
\hline $14 \mathrm{R}-1,93-97$ & Interst ol ox gabbro I & 52.50 & 0.824 & 0.318 & 24.35 & 0.642 & 20.00 & 1.182 & 0.013 & 0.0246 & 0.5795 & 0.3959 \\
\hline & & 0.44 & & & 0.3 & & 0.5 & & & & & \\
\hline $21 \mathrm{R}-1,82-89 \mathrm{CT}$ & Interst ol ox gabbro I & 53.19 & 0.892 & 0.3 & 23.42 & 0.6 & 21.26 & & & & & 0.3736 \\
\hline & & 0.14 & & & 0.0 & 0.0 & 0.3 & 0.2 & & & & 0.0030 \\
\hline $47 \mathrm{R}-2$ & ro I & 52.78 & 1.1 & 0.3 & 22.1 & 0.5 & 21. & & & & & 0.3553 \\
\hline $47 \mathrm{R}-3,143-149 \mathrm{CT}$ & & 52.9 & 0.6 & 0.2 & 25. & 0.6 & 19. & 1.8 & & & & 0.4056 \\
\hline $48 \mathrm{R}-2,56-65$ & Interst ol ox gabbro I & 53.39 & 0.7 & 0.2 & 23. & 0.6 & 20. & & & & & 0.3857 \\
\hline & & 0.1 & 0.0 & & 0. & 0.0 & 0. & 0.1 & 0. & & & 0.0170 \\
\hline 48R-3. & Inter & 53.0 & 0.7 & & 25 . & & 20. & & & & & 0.3987 \\
\hline $48 \mathrm{R}-4,82-8$ & Interst ol ox gabbro I & 52.3 & 0.7 & & 24. & & 20. & 1.1 & & 32 & & 0.4001 \\
\hline & & 0.9 & 0.0 & 0.0 & 0.3 & & & & & & & \\
\hline $49 \mathrm{R}-1,42-46$ & Interst ol ox gabbro I & 52.02 & & 0.2 & 24.5 & & $19.8-8-2$ & & 0. & & & 0.4013 \\
\hline & & 0.18 & 0.08 & 0.0 & 0.5 & 0.067 & 0. & 0.1 & & & & \\
\hline 50R-2, 43-47 & Interst ol ox gabbro I & 53.12 & 0.75 & 0.2 & 23.9 & 0.669 & 20. & 1.4 & & & & 0.3859 \\
\hline & & 0.52 & 0.08 & 0.03 & 0.3 & 0.03 & 0.2 & 0.1 & & & & \\
\hline 50R-3, 62-67 & Interst ol ox gabbro I & 52.38 & & & 24.2 & & 20. & 1.1 & & & & 0.3954 \\
\hline & & 0.46 & 0.130 & 0.03 & 0.66 & & 0.5 & 0.1 & & & & 0.0122 \\
\hline 51R-1, 94-99 & Interst ol ox gabbro I & 52.28 & 0.711 & 0.27 & 26.07 & 0.657 & 19.7 & 1.0 & 0.0 & 0.0205 & 0.5630 & 0.4165 \\
\hline & & 0.11 & 0.179 & 0.038 & 1.13 & & 0.7 & 0.2 & 0. & & & \\
\hline 51R-1, 99-103 & Interst ol ox gabbro I & 52.98 & & 0.295 & 24.37 & 0.6 & 20.75 & 1.4 & 0.0 & 0.02 & 0.5852 & 0.3857 \\
\hline & & 0.01 & 0.100 & 0.033 & 0.15 & 0.000 & 0.10 & 0.3 & 0.01 & & & 0.0032 \\
\hline $52 \mathrm{R}-3,121-123$ & Interst ol ox gabbro I & 52.62 & 0.851 & 0.210 & 25.87 & 0.682 & 19.40 & 0.993 & 0.000 & 0.0206 & 0.5603 & 0.4191 \\
\hline & & 0.27 & 0.511 & 0.031 & 0.83 & 0.027 & 0.02 & 0.060 & 0.000 & 0.0015 & 0.0071 & 0.0086 \\
\hline
\end{tabular}


Table 6 (continued).

\begin{tabular}{|c|c|c|c|c|c|c|c|c|c|c|c|c|}
\hline \multirow{2}{*}{$\begin{array}{l}\text { Core, section, } \\
\text { interval }(\mathrm{cm})\end{array}$} & \multirow[b]{2}{*}{ Rock type } & \multicolumn{11}{|c|}{ Orthopyroxene } \\
\hline & & $\mathrm{SiO}_{2}$ & $\mathrm{Al}_{2} \mathrm{O}_{3}$ & $\mathrm{TiO}_{2}$ & $\mathrm{FeO}$ & $\mathrm{MnO}$ & $\mathrm{MgO}$ & $\mathrm{CaO}$ & $\mathrm{Cr}_{2} \mathrm{O}_{3}$ & Wo & En & Fs \\
\hline \multirow[t]{2}{*}{$52 \mathrm{R}-4,88-94$} & Interst ol ox gabbro I & 51.70 & 0.694 & 0.265 & 26.89 & 0.800 & 17.59 & 1.223 & 0.005 & 0.0262 & 0.5242 & 0.4496 \\
\hline & & & 0.019 & 0.047 & 0.67 & 0.001 & 0.34 & 0.010 & 0.007 & 0.0002 & 0.0106 & 0.0108 \\
\hline \multirow[t]{2}{*}{$53 R-1,123-127$} & Interst ol ox gabbro I & 51.97 & 0.420 & 0.174 & 28.56 & 0.838 & 17.31 & 1.238 & 0.019 & 0.0260 & 0.5058 & 0.4683 \\
\hline & & 0.30 & 0.016 & 0.013 & 0.54 & 0.068 & 0.26 & 0.448 & 0.027 & 0.0092 & 0.0034 & 0.0126 \\
\hline $53 \mathrm{R}-2,31-39$ & Interst ol ox gabbro I & 51.42 & 0.696 & 0.290 & 26.91 & 0.658 & 17.12 & 2.198 & 0.006 & 0.0468 & 0.5065 & 0.4467 \\
\hline \multirow[t]{2}{*}{$54 \mathrm{R}-5,117-119$} & Interst ol ox gabbro I & 52.38 & 0.871 & 0.254 & 25.89 & 0.673 & 19.18 & 1.136 & 0.001 & 0.0237 & 0.5556 & 0.4208 \\
\hline & & 0.18 & 0.145 & 0.050 & 0.77 & 0.047 & 0.65 & 0.089 & 0.003 & 0.0020 & 0.0164 & 0.0144 \\
\hline \multirow[t]{2}{*}{$55 \mathrm{R}-2,101-105$} & Interst ol ox gabbro I & 51.41 & 0.448 & 0.179 & 28.31 & 0.851 & 16.59 & 1.446 & 0.006 & 0.0310 & 0.4949 & 0.4740 \\
\hline & & 0.35 & 0.099 & 0.046 & 0.96 & 0.060 & 1.03 & 0.5463 & 0.010 & 0.0122 & 0.0293 & 0.0178 \\
\hline \multirow[t]{2}{*}{$82 R-6,73-78$} & Interst ol ox gabbro I & 52.04 & 0.746 & 0.243 & 26.75 & 0.763 & 18.62 & 1.218 & 0.030 & 0.0254 & 0.5396 & 0.4350 \\
\hline & & 0.35 & 0.170 & 0.031 & 0.67 & 0.120 & 0.029 & 0.208 & 0.033 & 0.0043 & 0.0077 & 0.0115 \\
\hline \multirow[t]{2}{*}{$34 \mathrm{R}-4,8-12$} & Interst ol ox gabbro II & 52.61 & 0.986 & 0.303 & 23.65 & 0.617 & 20.3 & 1.277 & 0.011 & 0.0266 & 0.5892 & 0.3842 \\
\hline & & 0.18 & 0.151 & 0.052 & 0.42 & 0.059 & 0.25 & & & & & 0.0061 \\
\hline \multirow[t]{2}{*}{$47 R-3,56-61$} & Interst ol ox gabbro II & 52.82 & 0.785 & 0.268 & 23.67 & 0.618 & 20.89 & 1.091 & 0.020 & 0.0224 & 0.5976 & 0.3800 \\
\hline & & 0.25 & 0.166 & 0.042 & 1.12 & 0.034 & 0.63 & 0.175 & & 0.0035 & 0.0167 & 0.0189 \\
\hline \multirow[t]{2}{*}{$49 \mathrm{R}-2,94-100$} & Interst ol ox gabbro II & 53.17 & 0.790 & 0.222 & 23.34 & 0.610 & 21.31 & 1.092 & 0.010 & 0.0223 & 0.6055 & 0.3722 \\
\hline & & 0.30 & 0.073 & 0.042 & 1.35 & 0.058 & 1.03 & 0.199 & 0.0 & 0.0043 & 0.0252 & 0.0217 \\
\hline \multirow{2}{*}{$52 \mathrm{R}-1,91-100$} & Interst ol ox gabbro II & 52.20 & 0.989 & 0.225 & 25.45 & 0.637 & 19.60 & 1.087 & 0.010 & 0.0226 & 0.5654 & 0.4120 \\
\hline & & 0.37 & 0.291 & 0.026 & 0.52 & 0.048 & 0.51 & 0.130 & 0.011 & 0.0028 & 0.0107 & 0.0102 \\
\hline \multirow[t]{2}{*}{$54 R-1,131-136$} & Olivine oxide gabbro & 51.16 & 0.425 & 0.079 & 30.62 & 0.974 & 15.56 & 0.833 & 0.002 & 0.0180 & 0.4667 & 0.5153 \\
\hline & & 0.14 & 0.062 & 0.0 & 0.12 & 0.021 & 0.26 & 0.029 & & & 045 & 0.0043 \\
\hline \multirow{2}{*}{$54 \mathrm{R}-3,20-24$} & Olivine oxide gabbro & 51.26 & 0.410 & 0.169 & 33.07 & 0.960 & 13.78 & 1.465 & 0.0 & .0315 & 0.4127 & 0.5558 \\
\hline & & 0.05 & 0.046 & 0.021 & 0.13 & 0.085 & 0.18 & 0.285 & 0.018 & .0057 & 0.0010 & 0.0054 \\
\hline $54 \mathrm{R}-3,125-127$ & Olivine oxide gabbro & 50.73 & 0.365 & 0.115 & 29.29 & 0.894 & 14.93 & 2.984 & 0.0 & .0640 & 0.4456 & 0.4904 \\
\hline & & 0.06 & 0.006 & 0.019 & 0.01 & 0.042 & 0.08 & 0.071 & 0.030 & 0.0013 & 0.0007 & 0.0020 \\
\hline $55 \mathrm{R}-2,110-120$ & Olivine oxide gabbro & 52.57 & 0.804 & 0.296 & 25.56 & 0.714 & 19.77 & 1.210 & 0.0 & .0249 & 0.5651 & 0.4100 \\
\hline $55 \mathrm{R}-3,83-86$ & livine oxide gabbro & 52.61 & 0.435 & 0.203 & 28.56 & 0.762 & 17.35 & 2.148 & 0.0 & .0442 & 0.4969 & .4589 \\
\hline $56 \mathrm{R}-2,11-14$ & Olivine oxide gabbro & 51.51 & 0.467 & 0.198 & 31.40 & 0.959 & 14.89 & 1.1 & & & .4472 & 0.5290 \\
\hline & & 0.0 & 0.021 & 0.035 & 0.14 & 0.004 & 0.01 & 0.057 & 0.0 & .0012 & 0.0018 & 0.0006 \\
\hline $56 \mathrm{R}-2,49-52$ & Olivine oxide gabbro & 51.15 & 0.527 & 0.239 & 29.82 & 0.892 & 15.68 & 1.193 & 0.0 & & .4713 & 0.5029 \\
\hline & & 0.20 & 0.063 & 0.008 & 0.17 & 0.086 & 0.27 & 0.083 & 0.0 & .0020 & .0037 & 0.0017 \\
\hline $80 \mathrm{R}-3,67-71$ & Olivine oxide gabbro & 51.57 & 0.507 & 0.1 & 28.11 & 0.888 & 17.87 & 1.22 & & & .5178 & 0.4568 \\
\hline & & 0.28 & 0.118 & 0.0 & 1.19 & 0.081 & 0.55 & 0.055 & 0.0 & .0010 & 0.0183 & 0.0173 \\
\hline $80 R-6,130-135$ & Olivine oxide gabbro & 51.65 & 0.538 & 0.1 & 30.59 & 0.984 & 16.1 & & & & 4712 & 0.5013 \\
\hline & & 0.24 & 0.082 & 0.051 & 0.78 & 0.037 & 0.3 & 0.226 & 0.0 & .0049 & 0.0079 & 0.0104 \\
\hline $86 \mathrm{R}-4,123-130$ & Olivine oxide gabbro & 52.15 & 0.638 & 0.1 & 26.51 & 0.780 & 18.50 & & & & & 0.4333 \\
\hline & & 0.20 & 0.067 & 0.051 & 1.06 & 0.045 & 0.50 & 0.266 & 0.0 & .0056 & 0.0132 & 0.0173 \\
\hline $80 \mathrm{R}-7,10-1$ & 0 & 51.19 & 0.760 & 0.229 & 29.12 & 0.857 & 16.92 & & & & & 0.4784 \\
\hline $80 \mathrm{R}-7,23-25$ & Olivine oxide gabbro & 51.58 & 0.792 & 0.209 & 27.32 & 0.716 & 17.61 & 1.095 & 0.000 & 0.0233 & 0.5222 & 0.4545 \\
\hline $83 R-7,77-81$ & Troctolite & 57.50 & 0.739 & 0.092 & 9.01 & 0.232 & 32.58 & 0.556 & 0.078 & 0.0105 & 0.8566 & 0.1329 \\
\hline & & 0.12 & 0.208 & 0.037 & 0.06 & 0.036 & 0.64 & 0.148 & 0.108 & 0.0030 & 0.0041 & 0.0011 \\
\hline $73 R-3,73-75$ & Vermic cpx ol gabbro & 55.40 & 1.753 & 0.237 & 12.94 & 0.262 & 28.81 & 0.880 & 0.093 & 0.0172 & 0.7849 & 0.1979 \\
\hline & & & & & 0.32 & 0.044 & 0.5 & & & & & \\
\hline $81 \mathrm{R}-5,1-7$ & Vermic cpx ol gabbro & 55.25 & 1.932 & 0.165 & 12.90 & 0.277 & 28.59 & & & & & 0.1990 \\
\hline $71 \mathrm{R}-2,82-84$ & Vermic cpx ol gabbro & 54.62 & 1.228 & 0.378 & 14.63 & 0.366 & 27.24 & 0.964 & 0.0 & & & 0.2272 \\
\hline & & 0.31 & 0.138 & 0.161 & 0.98 & 0.013 & 1.00 & 0.184 & 0.030 & 0.0038 & 0.0210 & 0.0172 \\
\hline $62 \mathrm{R}-4,21-24$ & Olivine gabbro & 54.99 & 1.448 & 0.348 & 16.11 & 0.384 & 26.94 & 0.989 & 0.020 & & & \\
\hline & & & & & & & & & & & & \\
\hline $59 \mathrm{R}-4,29-35$ & Olivine gabbro & 54.98 & 1.252 & 0.234 & 16.51 & 0.393 & 26.56 & 0.7 & 0.0 & & & 0.2549 \\
\hline & & 0.36 & & & 0.83 & & 0.67 & & 0.0 & & 0.0149 & 0.0141 \\
\hline $60 \mathrm{R}-1,18-20$ & Olivine gabbro & 53.71 & 1.412 & 0.351 & 16.21 & 0.359 & 26.09 & 0.930 & 0.0 & & 0.7278 & 0.2536 \\
\hline & & 0.35 & & 0.081 & 0.84 & 0.001 & 0.30 & 0.129 & 0.0 & & 0.0138 & 0.0113 \\
\hline $31 \mathrm{R}-2,120-122$ & Olivi & 53.52 & 2.055 & 0.361 & 16.52 & 0.290 & 26.05 & 1.159 & 0.0 & 0.0230 & 0.7205 & 0.2565 \\
\hline $59 \mathrm{R}-3,70-72$ & Olivine gabbro & 54.31 & 1.366 & 0.297 & 17.81 & 0.406 & 25.77 & 0.872 & 0.026 & & 0.7079 & 0.2748 \\
\hline & & 0.43 & 0.242 & 0.100 & 0.99 & 0.051 & 0.99 & 0.171 & 0.018 & 0.0035 & 0.0207 & 0.0177 \\
\hline
\end{tabular}

Note: Standard deviations are also shown below the average of oxide weight percent. Abbreviations are the same as in Table 3 .

bell, 1977) and from the marginal zone in the Muskox Intrusion (Bahattacharji and Smith, 1964). These marginal cumulates occupy the lower portions of the intrusions filling connecting pipes. In the upper border group of the Skaergaard Intrusion, a downward trend to more evolved compositions has been interpreted as crystallization from the roof downward in the intrusion (Wager and Brown, 1967; Naslund, 1984).

The unimodal distribution of the mineral chemistry among the Fe-Ti oxide gabbros (Fig. 1) indicates that they might have been derived from a common, moderately fractionated magma, which may have existed either at the top or on the side of the cumulus pile of olivine gabbro. In the former case, the evolved magma may have intruded downward into the pile with progressive fractional crystallization. In the latter case, the chamber may have been reversely stratified and lateral intrusion occurred. The lateral intrusion model seems unrealistic because it is difficult to maintain a reversely stratified magma chamber (Sparks and Huppert, 1984); the melt in equilibrium with the most evolved gabbros, the olivine Fe-Ti oxide gabbros, deep in the section likely was higher in silica and lower in iron so had a lower density than the melt in equilibrium with the less evolved gabbronorites and pigeonite gabbros higher in the section so would have risen through the cumulus pile. 

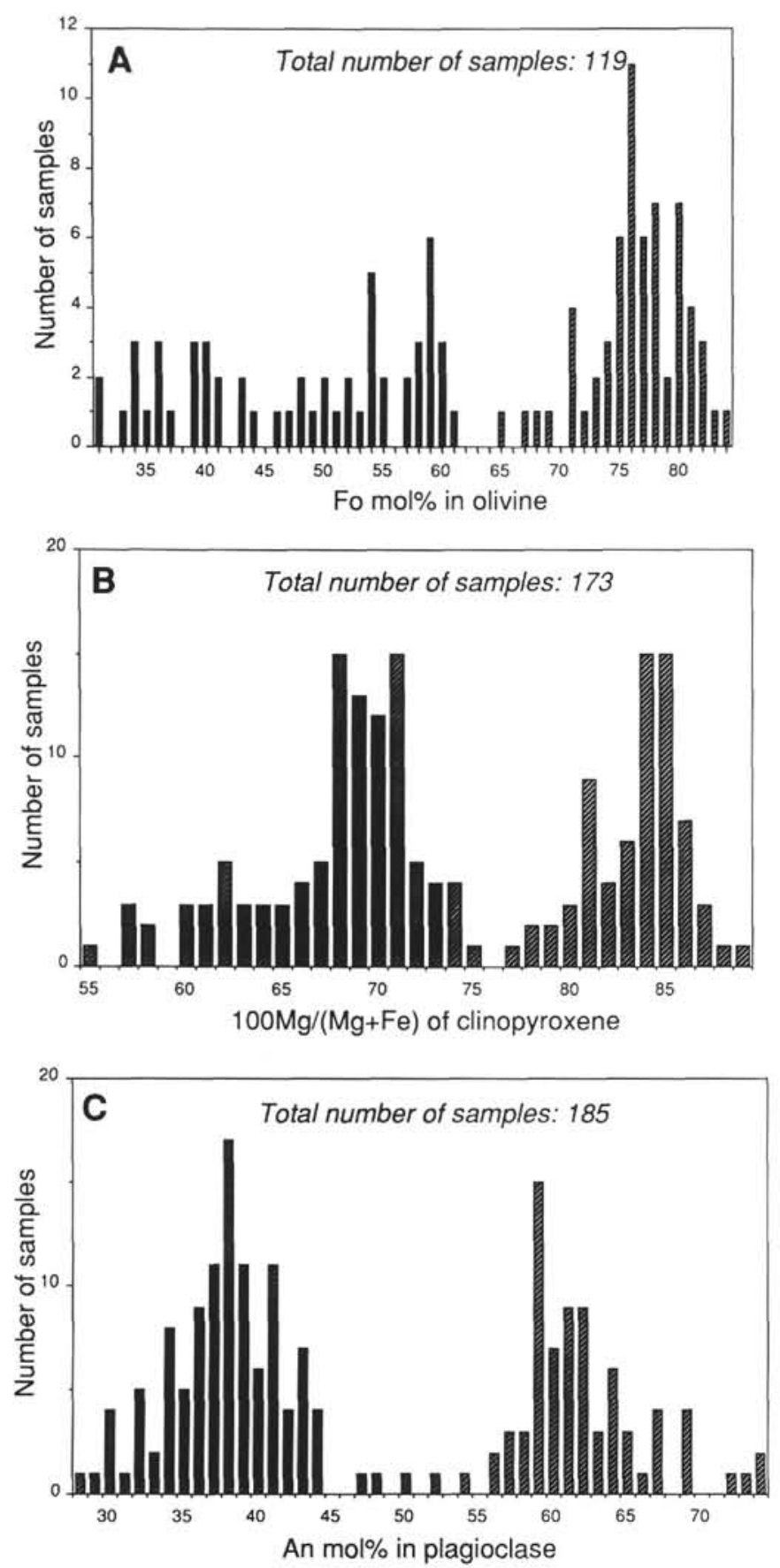

Figure 4. A. Frequency histograms of average Fo mol\% in olivine. B. Average $100 \mathrm{Mg} /(\mathrm{Mg}+\mathrm{Fe})$ of clinopyroxene. C. Average An mol\% in plagioclase in gabbros from Hole 735B. Note that histograms show bimodal distribution pattern, specifically for $\mathrm{An} \mathrm{mol} \%$ and $\mathrm{Mg}$ / $(\mathrm{Mg}+\mathrm{Fe})$ ratio of clinopyroxene. Each peak corresponds to olivine gabbro-troctolite and iron-titanium oxide gabbros.

The downward intrusion of fractionated magma into a solidifying cumulus pile is plausible if magma chambers beneath mid-ocean ridges are chemically zoned, as proposed by Pallister and Hopson (1981) and Casey and Karson (1981). In their models, magma situated at the margin of the chamber, and away from the spreading center, is more evolved than that at the center of the chamber. A similar zonation may be attained in a small ephemeral magma chamber with limited supply of primitive magmas. In such a case, evolved melt may overly a completely- or almostsolidified cumulus pile of primitive gabbros. Disrupting the cumulus pile may have caused the overlying evolved magma to fill the fractures and crystallize as a dike- and sillcomplex. Progressive downward intrusion may have caused continued evolution; thus, the deeper intrusives show more evolved characteristics. The contact relationship between olivine gabbro and Fe-Ti oxide gabbro suggests that the magma body should have been cooled from the base. In a steady state magma chamber model, this situation may only be achieved if the intrusion took place away from the ridge center, assuming a deep hydrothermal cell (Morton and Sleep, 1985). This indicates that the evolved melt may have existed away from the accretion center, which is consistent with the zoned magma chamber model mentioned above. The downward evolution of Fe-Ti oxide gabbros in Unit IV can be explained by downward crystallization from the roof of a thick dike. Accordingly, the base of Unit IV may correspond to the proximity of the center of the dike, the lower half of which was displaced by faulting and is missing from the section of Hole $735 \mathrm{~B}$.

\section{SUMMARY}

The major petrological characteristics of gabbros from Hole $735 \mathrm{~B}$ are (1) the intimate association of evolved (Fe-Ti oxide gabbro) and primitive (olivine gabbro and troctolite) gabbros, with rare gabbros having intermediate mineral chemistry, (2) the likely co-genetic relationship between evolved and primary gabbros suggested by systematic mineralogical variations among all the gabbros from Hole 735B, and (3) the sharp contacts between evolved and primitive and evolved gabbros, suggesting that these contacts were formed by the intrusion of evolved magma into solid or almost solidified olivine gabbro host.

We suggest that a body of fairly homogeneous olivine gabbro cumulates formed on the floor and walls of a magma chamber. This isotropic (unlayered) unit of gabbro cumulates was overlain by a body of isolated melt which fractionated to produce gabbronorites and dense iron-rich melts that migrated back into the cumulate pile along cooling and deformation fractures. Downward penetration of melt led to further fractionation and the production of evolved gabbros rich in $\mathrm{Fe}-\mathrm{Ti}$ oxides. This model requires an unreplenished ephemeral magma chamber (Meyer et al., 1989) which is consistent with low magma supply rates along the Southwest Indian Ridge (Dick et al., 1984). High cooling rates and extensive fractional crystallization may have been enhanced by the proximity to the Atlantis II Fracture Zone.

\section{ACKNOWLEDGMENTS}

We wish to thank the scientists, technicians, officers, and crew aboard the JOIDES Resolution, and the shore-based ODP staff for their support and cooperation during and after Leg 118 . We are grateful to Toshitsugu Fujii, Hiroko Nagahara, and Natsuko Takahashi for fruitful discussions and encouragements. This paper benefitted considerably from the many comments by Peter Thy.

\section{REFERENCES}

Ambler, E. P., and Ashley, P. M., 1977. Vermicular orthopyroxenemagnetite symplectites from the Wateranga layered mafic intrusion, Queensland, Australia. Lithos, 10:163-172.

Batiza, R., and Vanko, D. A., 1985. Petrologic evolution of large failed rifts in the eastern Pacific: petrology of volcanic and plutonic rocks from the Mathematician Ridge area and the Guadalupe Trough. J. Petrol., 26:564-602. 
Bhattacharji, S., and Smith, C. H., 1964: Flowage differentiation. Science, 145:150-153.

Bowen, N. L., and Schairer, J. F., 1935. The system MgO-FeO-SiO 2 . Am. J. Sci., 26:151-217.

BVSP, 1981. Basaltic Volcanism on the Terrestrial Planets: (Lunar and Planetary Institution), New York (Pergamon Press).

Casey, J. F., and Karson J. A., 1981. Magma chamber profiles from the Bay of Islands ophiolite complex. Nature, 292:295-301.

Campbell, I. H., 1977. A study of macro-rhythmic layering and cumulus processes in the Jimberiana Intrusion, Western Australia. Part I: The upper layered series. J. Petrol., 189:183-215.

Davidson, P. M., and Lindsley, D. H., 1989. Thermodynamic analysis of pyroxene-olivine-quartz equilibria in the system $\mathrm{CaO}-\mathrm{MgO}$ FeO-SiO ${ }_{2}$. Am. Mineral., 74:18-30.

Elthon D., 1987. Petrology of Gabbroic rocks from the Mid-Cayman Rise spreading center. J. Geophys. Res., 92:658-682.

Hébert, R., Bideau, D., and Hekinian, R., 1983. Ultramafic and mafic rocks from the Garret Transform Fault near $13^{\circ} \mathrm{N} 30^{\prime} \mathrm{S}$ on the East Pacific Rise: igneous petrology. Earth Planet. Sci. Lett., 65:107-125.

Hodges, F. N., and Papike, J. J., 1976. DSDP site 334: Magmatic cumulates from oceanic layer 3. J. Geophys. Res., 81:4135-4151.

Hoover, J. D., 1978. Petrologic features of the Skaergaard marginal border group. Year Book, Carnegie Instn. Wash., 77:732-739.

Meyer, P. S., Dick, J. B., and Thompson, G., 1989. Cumulate gabbros from the Southwest Indian Ridge, $54^{\circ} \mathrm{S}-7^{\circ} 16^{\prime} \mathrm{E}$ : implications for magmatic processes at a slow spreading ridge. Contrib. Mineral. Petrol., 103:44-63.

Miyashiro, A., and Shido, F., 1980. Differentiation of gabbros in the Mid-Atlantic Ridge near $24^{\circ} \mathrm{N}$. Geochem. J. 14:145-154.

Morton, J. L., and Sleep, N. H., 1985. A mid-ocean ridge thermal model: constraints on the volume of axial hydrothermal heat flux. J. Geophys. Res., 90:11345-11353.
Nakamura, Y., and Kushiro, I., 1970. Compositional relationships of coexisting orthopyroxene, pigeonite and augite in a tholeiitic andesite from Hakone volcano. Contrib. Mineral. Petrol., 26:265-275.

Naslund, H. R., 1984. Petrology of the Upper Border Series of the Skaergaard intrusion. J. Petrol., 25:185-212.

1976. Mineralogical variations in the upper part of the Skaergaard intrusion, East Greenland. Year Book, Carnegie Instn. Wash., 75:640-644.

Pallister, J. S., and Hopson, C. A., 1981. Samail ophiolite plutonic suite: field relations, phase variation, cryptic variation and layering, and a model of a spreading ridge magma chamber. J. Geophys. Res., 86:2593-2644.

Robinson, P. T., Von Herzen, R., et al., 1989: Proc. ODP, Init. Repts., 118: College Station, TX (Ocean Drilling Program).

Sinton, J. M., Wilson, D. S., Christie, D. M., Hey, R. N., and Delaney, J. R., 1983. Petrologic consequences of rift propagation on oceanic spreading rides. Earth Planet. Sci. Lett., 62:193-207.

Sparks, R. S., and Huppert, H. E., 1984. Density changes during the fractional crystallization of basaltic magmas: fluid dynamic implications. Contrib. Mingral. Petrol., 85:300-309.

Tiezzi. L. J., and Scott, R. B., 1980. Crystal fractionation in a cumulate gabbro, Mid-Atlantic Ridge, $26^{\circ}$ N. J. Geophys. Res., $85: 5438-5454$.

Wager, L. R., and Brown, G. M., 1967. Layered Igneous Rocks: San Francisco (Freeman).

Walker, D., and Delong, S. E., 1984. A small Soret effect in spreading center gabbros. Contrib. Mineral. Petrol., 85:203-208.

Date of initial receipt: 19 October 1989

Date of acceptance: 26 June 1990

Ms 118B-125 

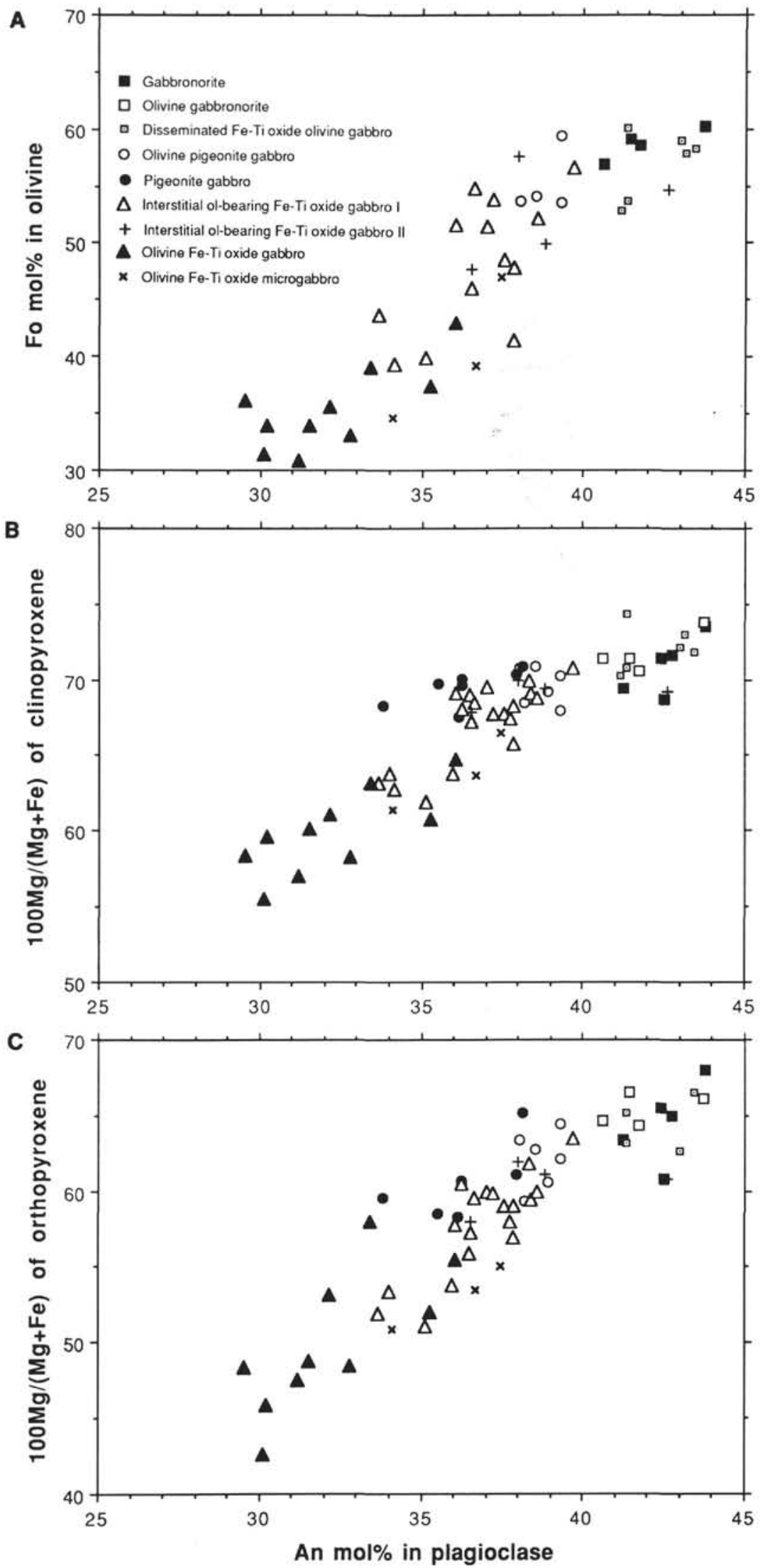

Figure 5. Average An content in plagioclase vs. average $\mathrm{Mg} /(\mathrm{Mg}+\mathrm{Fe})$ ratios of mafic minerals (A, Olivine. B, Clinopyroxene (augite-diopside), C, Orthopyroxene) in Fe-Ti oxide gabbros from Hole 735B. Symbols are the same as in Figure 3. 
A

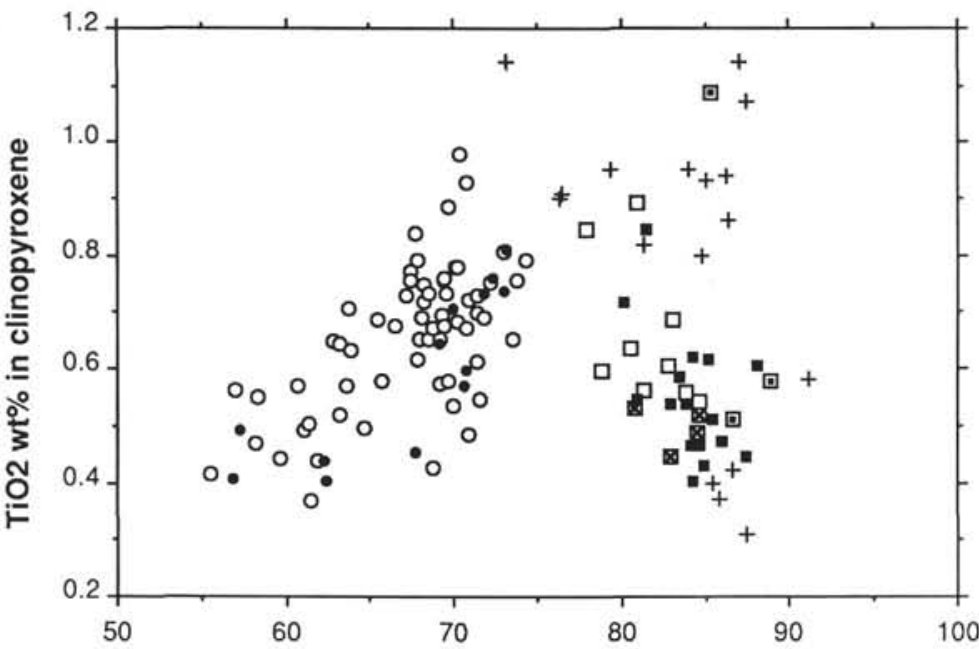

B

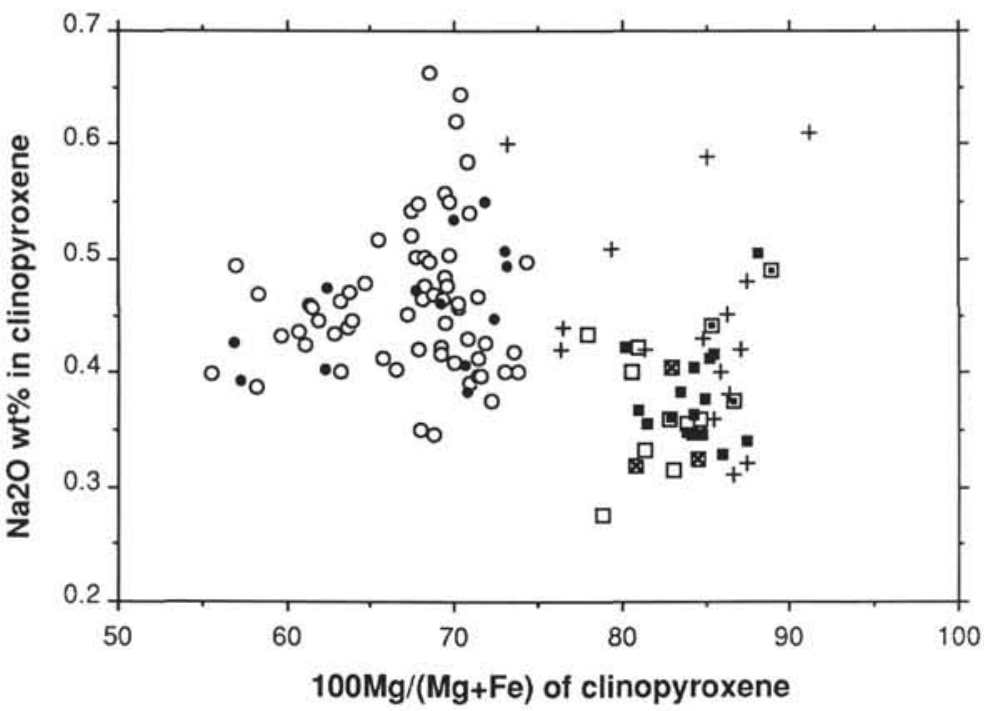

Figure 6. $\mathrm{TiO}_{2}$ content (A) and $\mathrm{Na}_{2} \mathrm{O}$ content (B) vs. $\mathrm{Mg} /(\mathrm{Mg}+\mathrm{Fe})$ ratio of clinopyroxene (augite-diopside). Data are based on average of clinopyroxene cores. Symbols are the same as in Figure 4. 


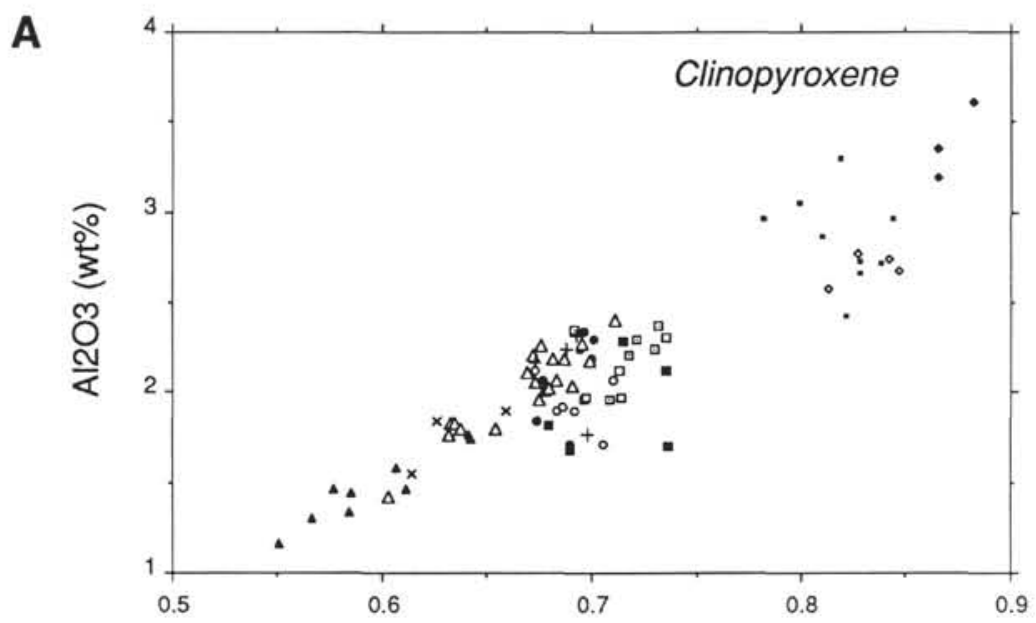

B

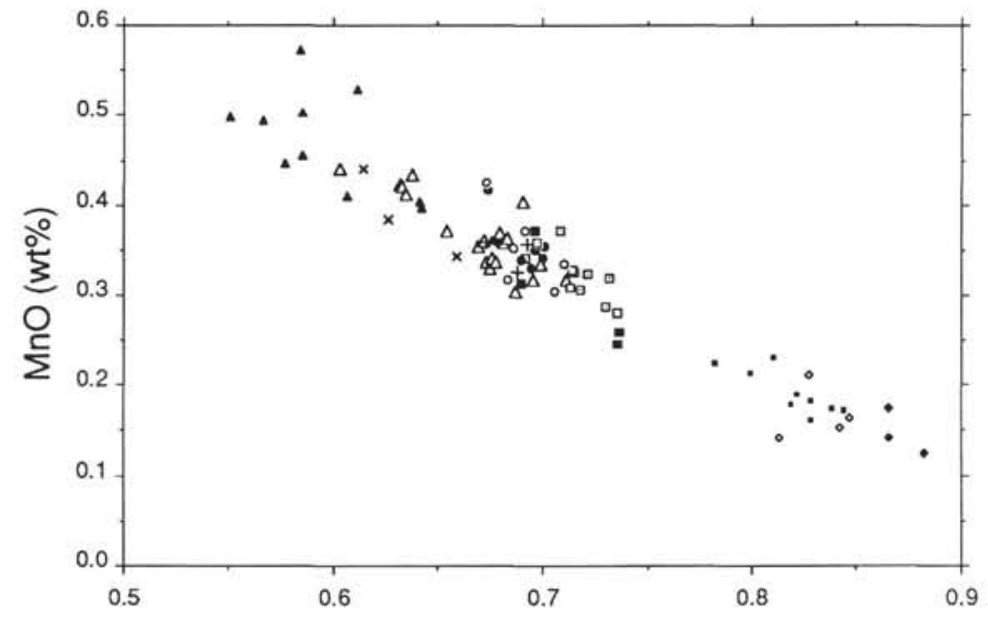

C

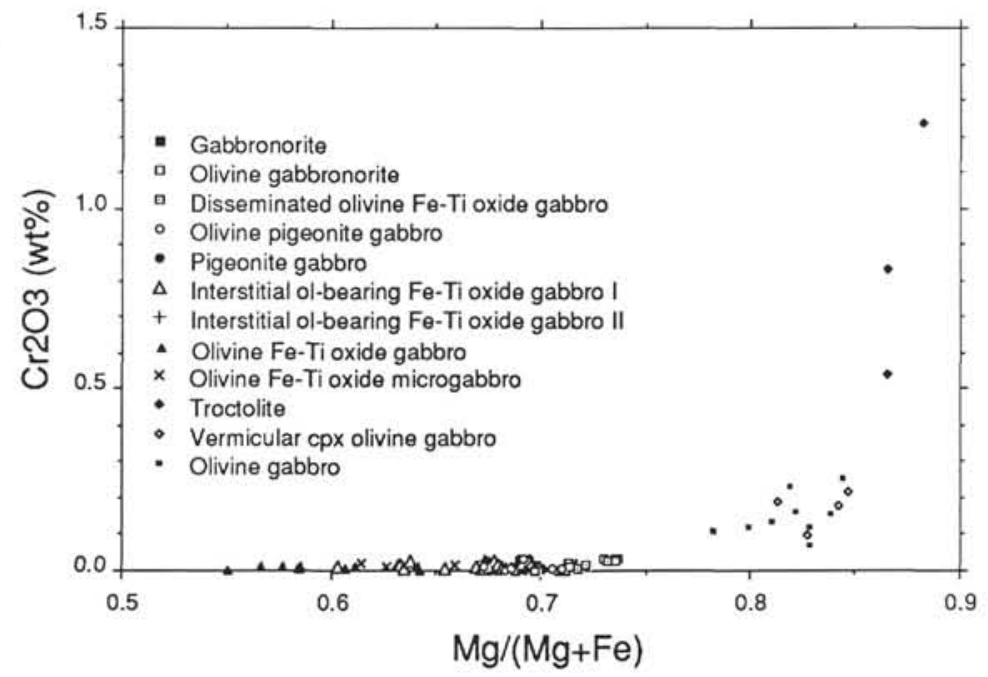

Figure 7. $\mathrm{Mg} /(\mathrm{Mg}+\mathrm{Fe})$ ratio vs. $\mathrm{Al}_{2} \mathrm{O}_{3}(\mathbf{A}), \mathrm{MnO}$ (B), and $\mathrm{Cr}_{2} \mathrm{O}_{3}$ (C) contents of clinopyroxene. Symbols are the same as in Figure 3, except for troctolite (solid diamond), vermicular clinopyroxene olivine gabbro (open diamond), and olivine gabbro (small solid square). 
A

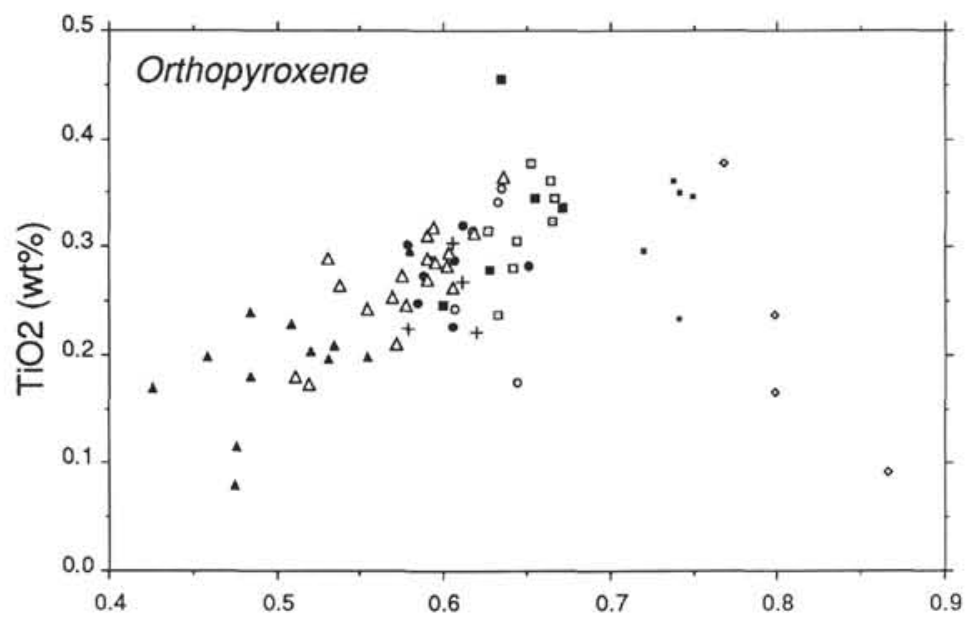

B

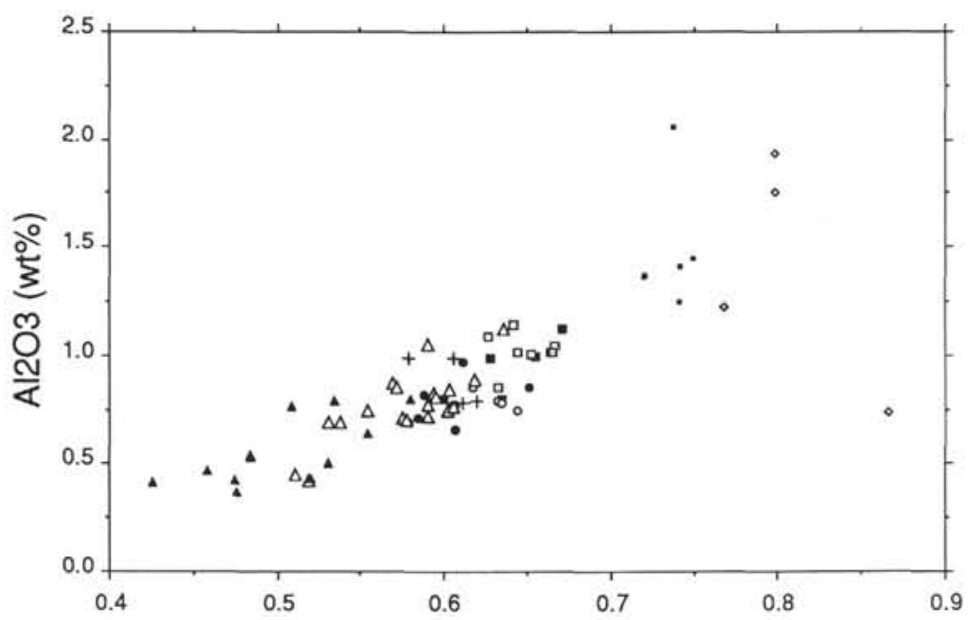

C

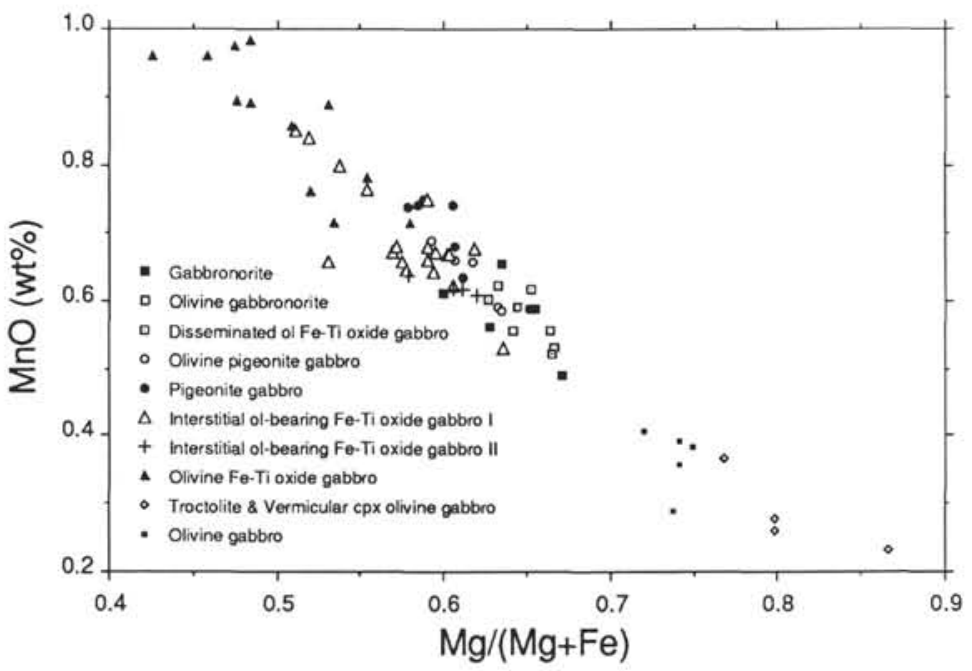

Figure $8 . \mathrm{Mg} /(\mathrm{Mg}+\mathrm{Fe})$ ratio vs. $\mathrm{TiO}_{2}(\mathbf{A}), \mathrm{Al}_{2} \mathrm{O}_{3}(\mathbf{B})$, and $\mathrm{MnO}(\mathbf{C})$ contents of orthopyroxene. Symbols are the same as in Figure 7. 


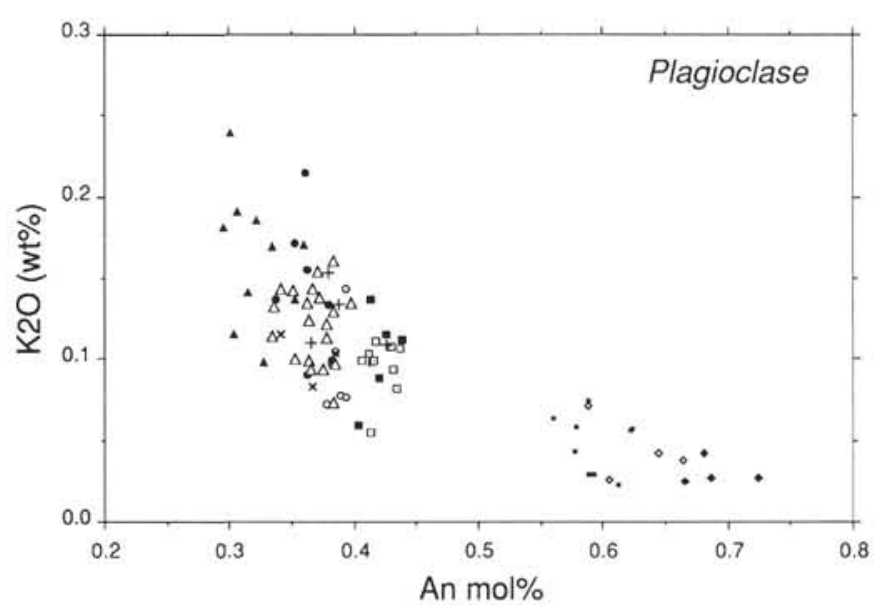

Figure 9. Anorthite mol\% vs. Orthoclase mol\% in plagioclase. Symbols are the same as in Figure 7.
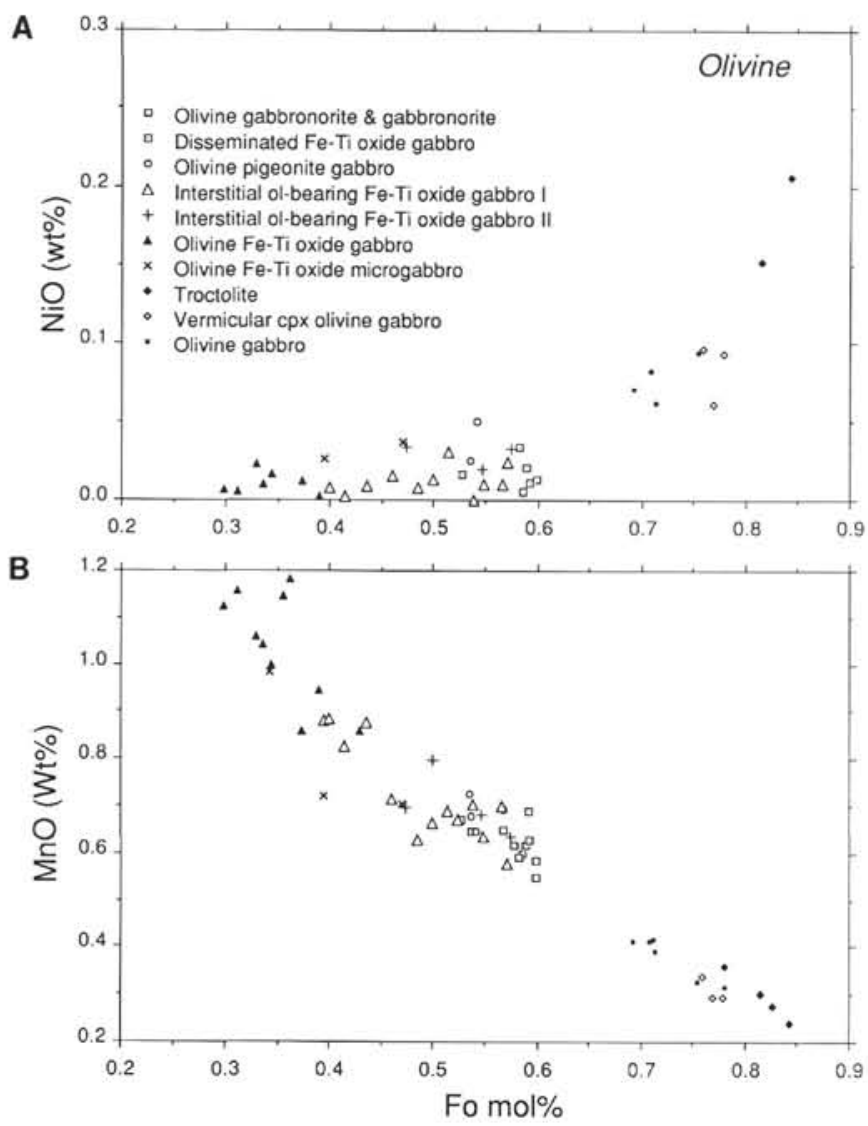

Figure 10. Fo mol\% vs. $\mathrm{NiO}$ (A) and $\mathrm{MnO}$ (B) contents of olivine. Symbols are the same as in Figure 7.
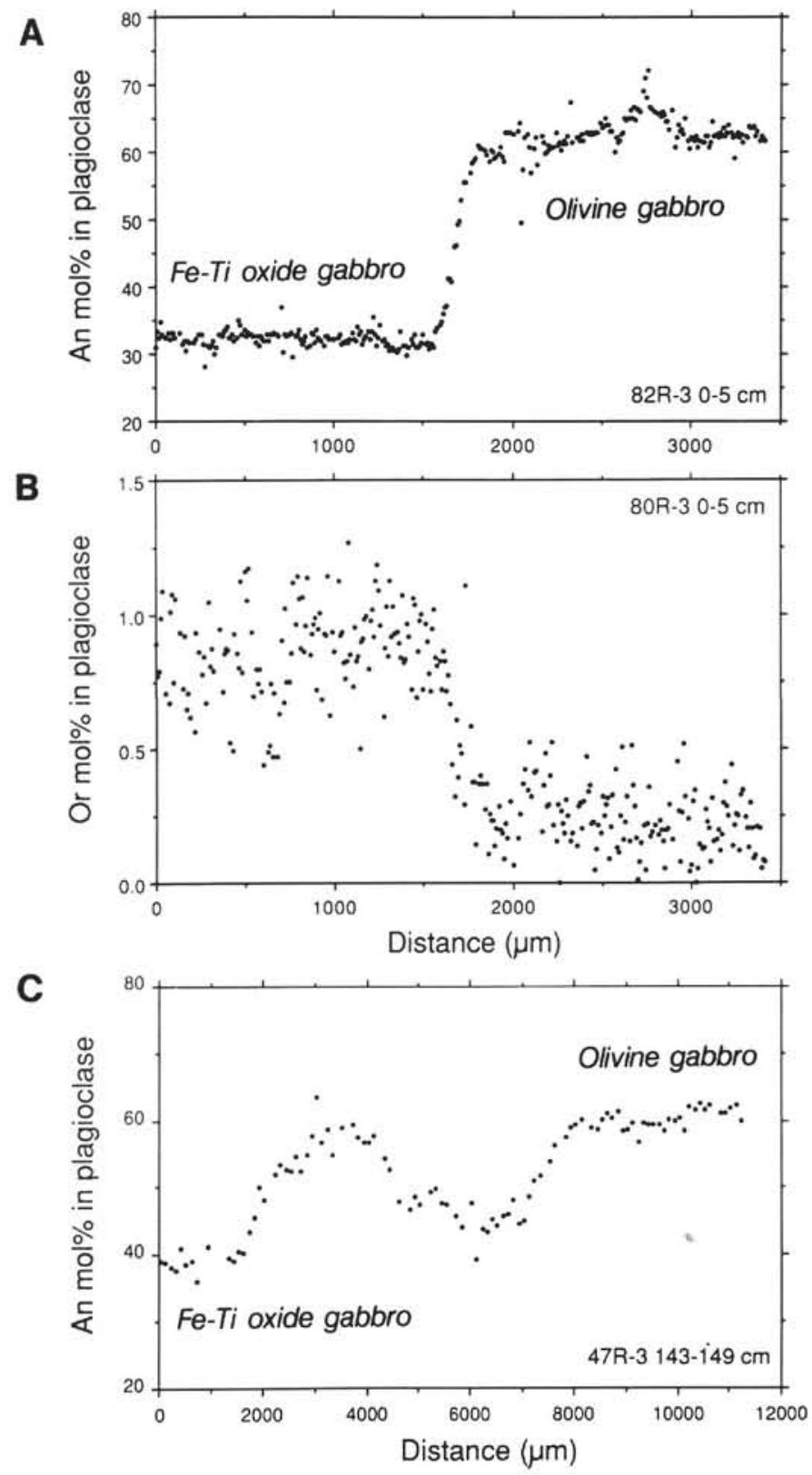

Figure 11. Step scanning profiles of plagioclase composition at the contact between troctolitic olivine gabbro and extremely evolved Fe-Ti oxide gabbro (A)-(B) (Sample 118-735B-82R-3, 0-5 cm) and olivine gabbro and Fe-Ti oxide gabbro (C) (Sample 118-735B-47R-3, 143-149). Note the difference of scales in (A)-(B) and (C). A calcium-rich peak at the contact of Sample 118-735B-47R-3, 143-149 $\mathrm{cm}(\mathrm{C})$ corresponds to a zoned calcic plagioclase of the olivine gabbro. 


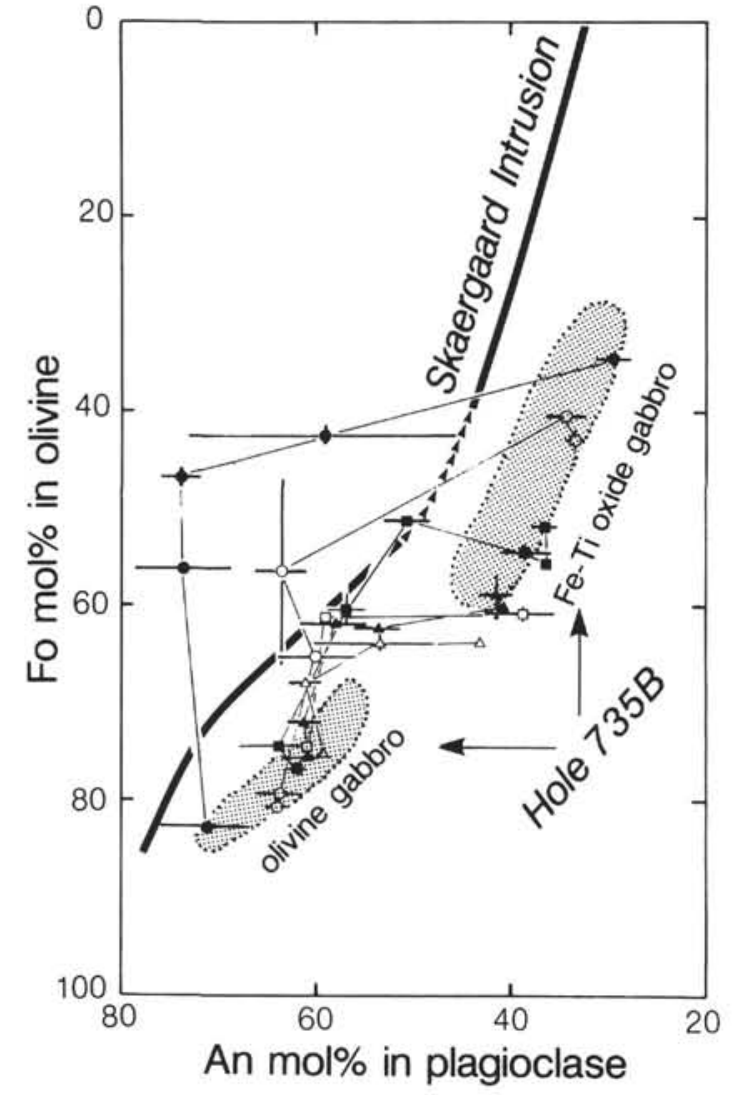

Figure 12. Anorthite content of plagioclase vs. Forsterite mol\% of olivine at contacts between olivine gabbro and $\mathrm{Fe}$-Ti oxide gabbro. Data for each contact are connected by a line. Olivine and plagioclase occurring nearby are paired. Bars indicate compositional ranges. Samples are; solid circle: 118-735B-79R-7, 2-9 cm, open circle: 118-735B-82R-3, 0-5 cm, solid square: 118-735B-47R-3, $143-149 \mathrm{~cm}$, solid triangle: $118-735 \mathrm{~B}-76 \mathrm{R}-3,35-41 \mathrm{~cm}$, open square: $118-735 \mathrm{~B}-$ 10D-2, 20-24 cm, open triangle: $118-735 \mathrm{~B}-76 \mathrm{R}-1,63-70 \mathrm{~cm}$. Arrows on the Skaergaard trend indicate the temporal cessation of olivine crystallization. Bars indicate ranges of the chemical compositions. At each contact, upon crossing the boundary from olivine gabbro to $\mathrm{Fe}-\mathrm{Ti}$ oxide gabbro, first Fo mol\% changes markedly keeping plagioclase composition constant, but at the contact An mol\% changes dramatically.
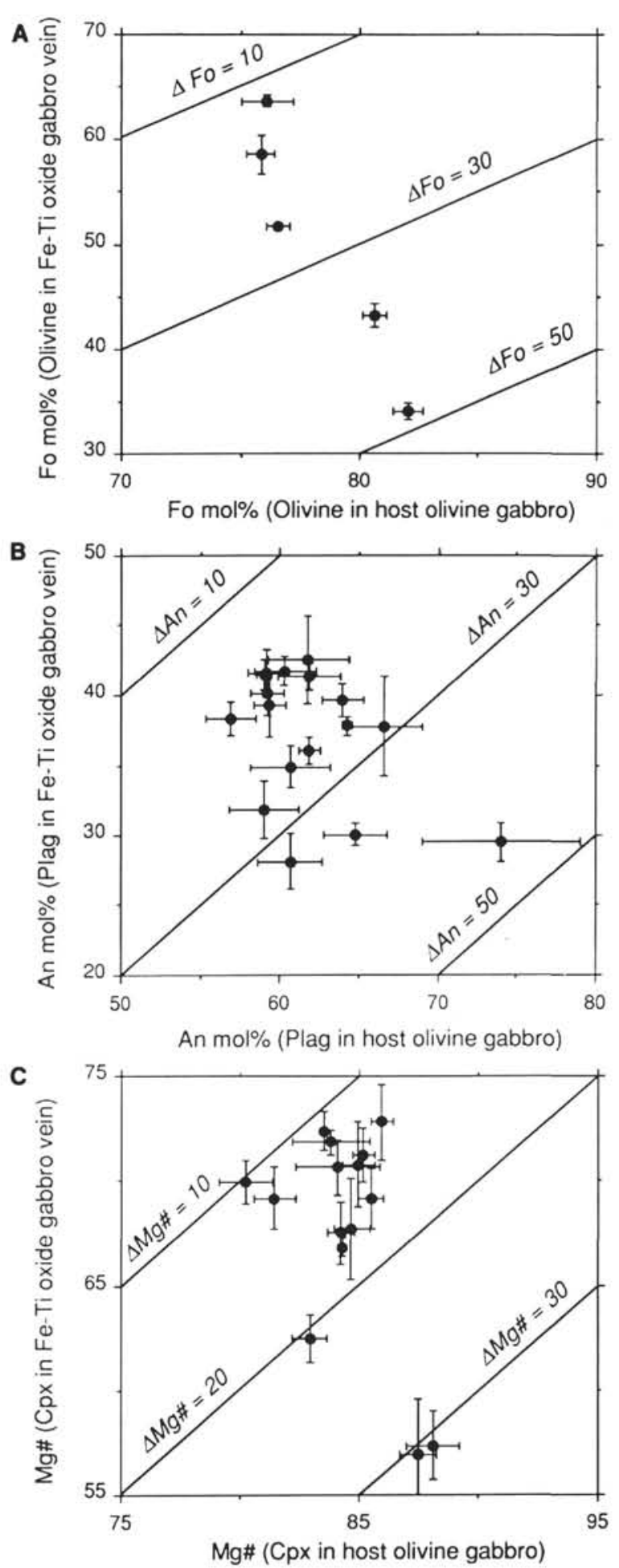

Figure 13. Relationships between chemical composition of olivine (A), plagioclase (B), and clinopyroxene (C) in olivine gabbro and $\mathrm{Fe}$-Ti oxide gabbro in contact with each other. $\Delta \mathrm{Fo}, \Delta \mathrm{An}$, and $\Delta \mathrm{Mg} \#$ imply Fo of olivine, An of plagioclase, and $\mathrm{Mg} \#$ of clinopyroxene in host olivine gabbro minus Fo of olivine, An of plagioclase, and $\mathrm{Mg \#}$ of clinopyroxene in Fe-Ti oxide gabbro vein, respectively. Bars indicate standard deviations. The data for olivine gabbro and troctolite were obtained 1-3 cm away from the contact and exhibit pristine composition without chemical effect of intruded evolved melts. 


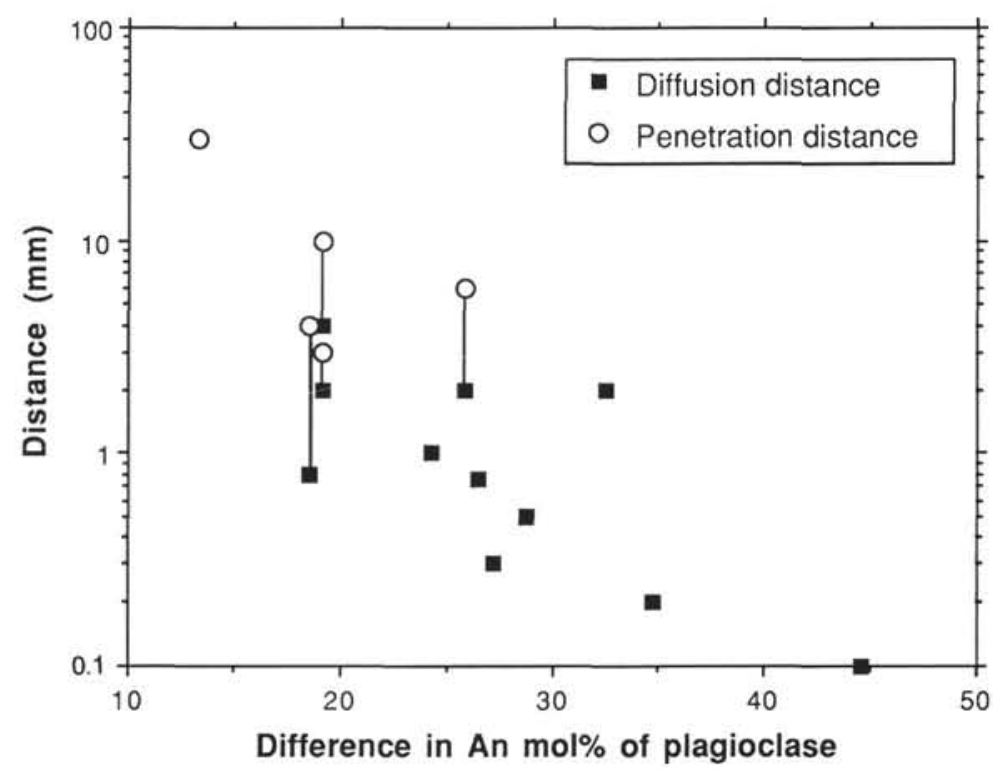

Figure 14. Relationships between compositional difference of plagioclase in contacting olivine and $\mathrm{Fe}-\mathrm{Ti}$ oxide gabbros, and diffusion or penetration distance observed in plagioclase. Diffusion distance implies the zoned width in single plagioclase at the contact. Penetration distance implies the width within which plagioclase in olivine gabbro shows chemical heterogeneity commonly from the grain boundaries toward inside the grains. Vertical lines connect data for the same sample. 


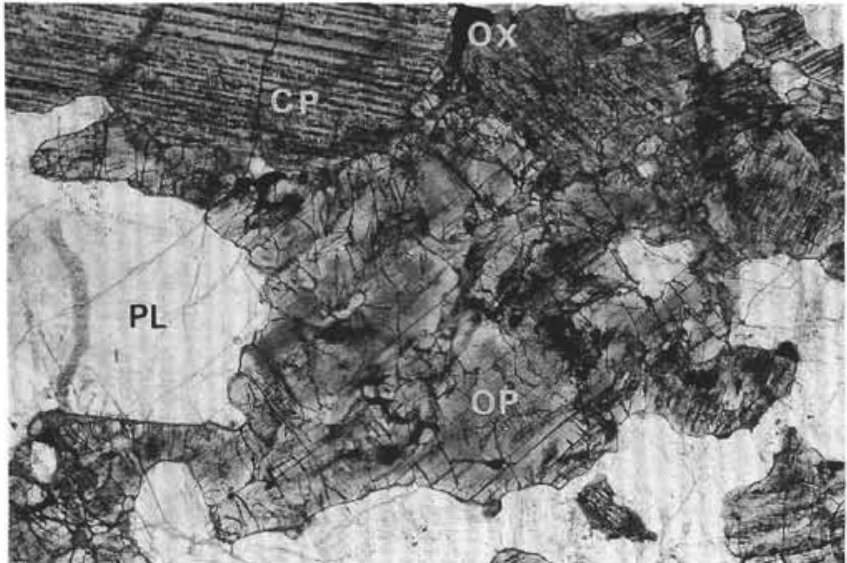

1

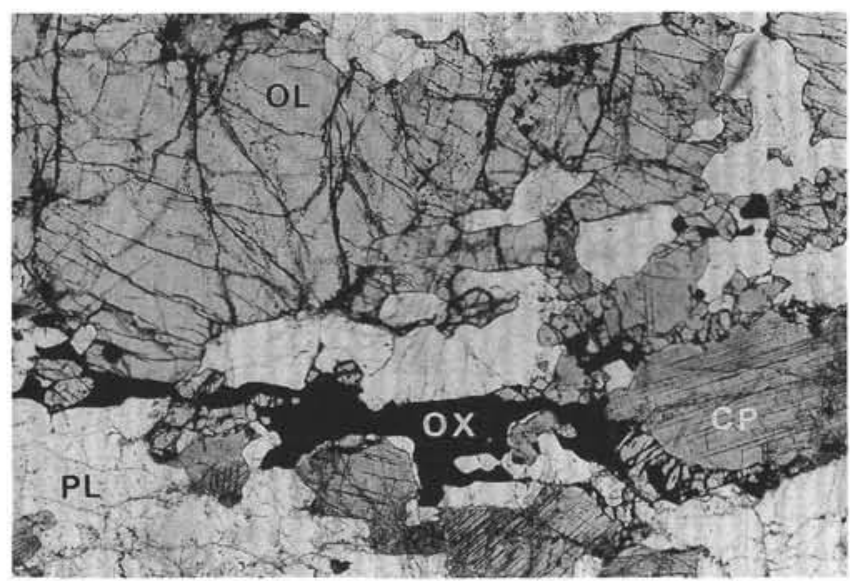

3

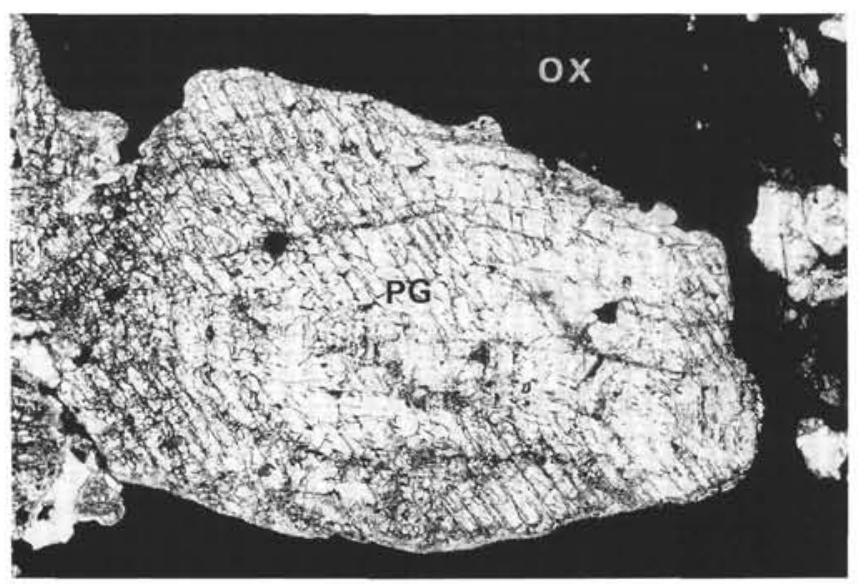

5

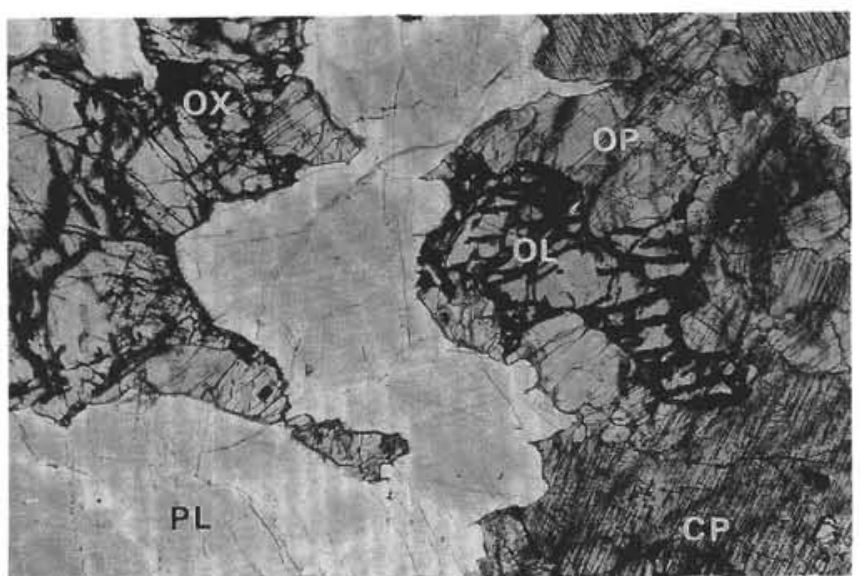

2

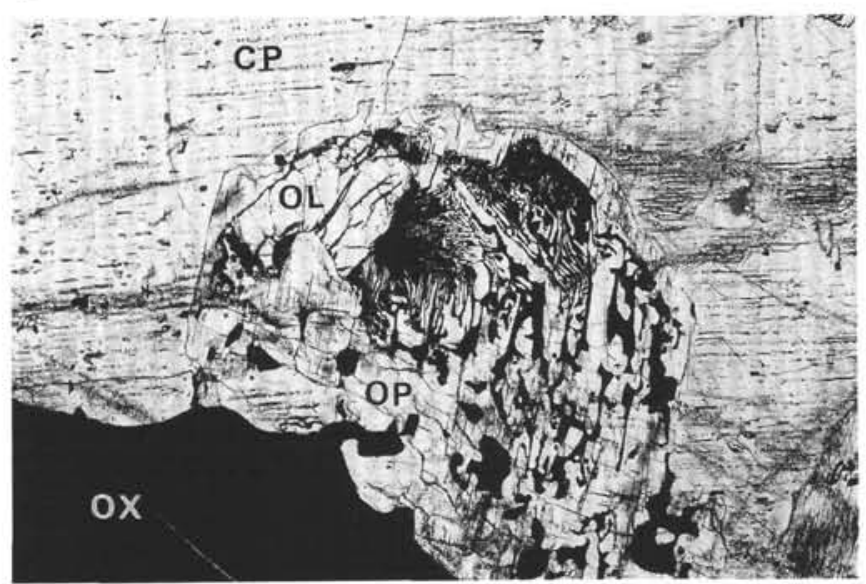

4

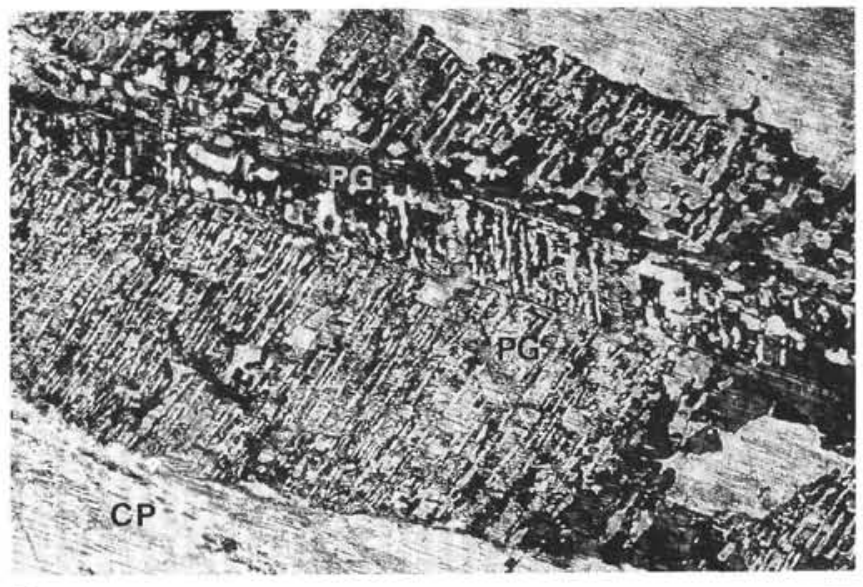

6

Plate 1. Thin section photomicrograph of Fe-Ti oxide gabbros. Scale bar is $1 \mathrm{~mm}$ long for all the photos. 1. Sample 118-735B-76R-4, 12-19 cm. Gabbronorite containing plagioclase, orthopyroxene and clinopyroxene with small amount of Fe-Ti oxides. 2. Sample 118-735B-40R-5, 0-4 cm. Olivine gabbronorite containing plagioclase, olivine, orthopyroxene, and clinopyroxene with small amount of Fe-Ti oxides. 3. Sample 118-735B-46R-3, 121-128 cm. Disseminated Fe-Ti oxide olivine gabbro containing plagioclase, large olivine, clinopyroxene, and Fe-Ti oxides. 4. Sample 118-735B-76R-1, 63-70 cm. Gabbronorite in contact with olivine gabbro. The photomicrograph shows orthopyroxene and Fe-Ti oxides symplectite surrounding olivine. The corona structure is observed only very close to the contact. 5. Sample $118-735 \mathrm{~B}-38 \mathrm{R}-3,80-85 \mathrm{~cm}$. Inverted pigeonite surrounded by Fe-Ti oxides in olivine pigeonite gabbro. 6. Sample 118-735B-38R-3, $85-88 \mathrm{~cm}$. Inverted pigeonite in the core of clinopyroxene in pigeonite gabbro. Inverted pigeonite is also present as an isolated grain. Abbreviations in the photos are; OL: olivine, PL: plagioclase, OP: orthopyroxene, CP: clinopyroxene, PG: inverted pigeonite, OX: Fe-Ti oxides. 

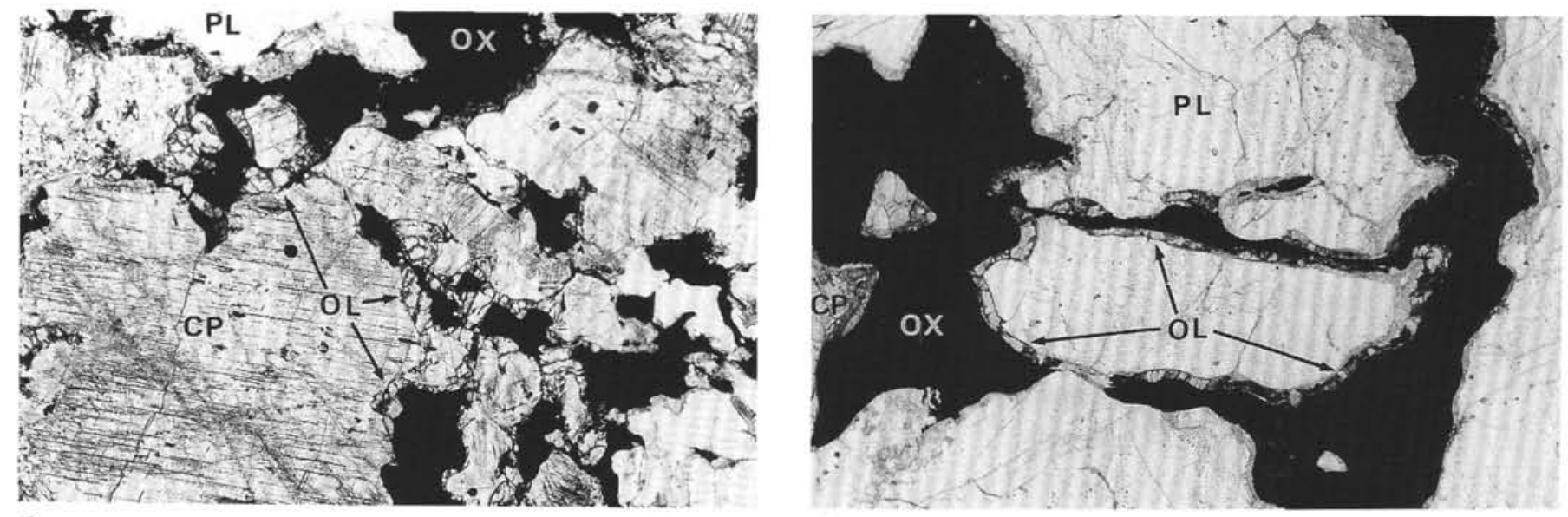

1

2

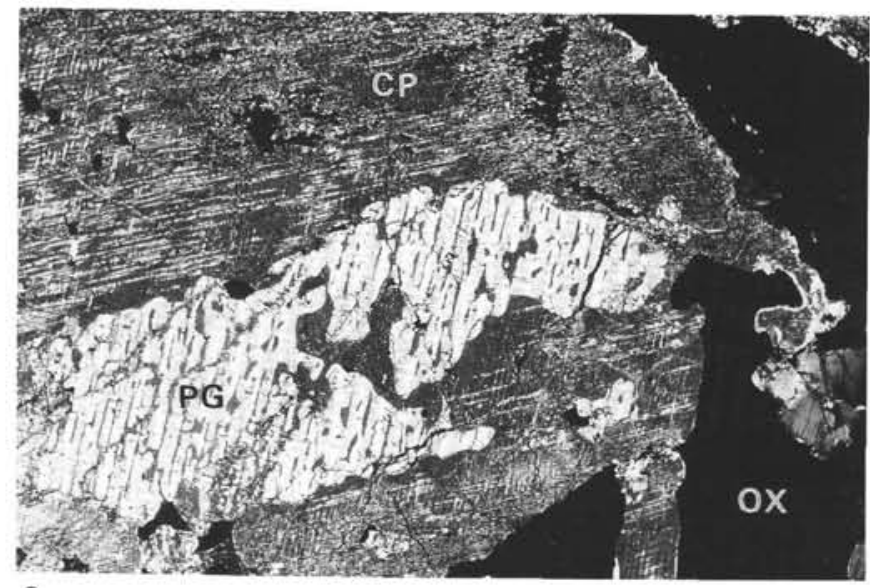

3

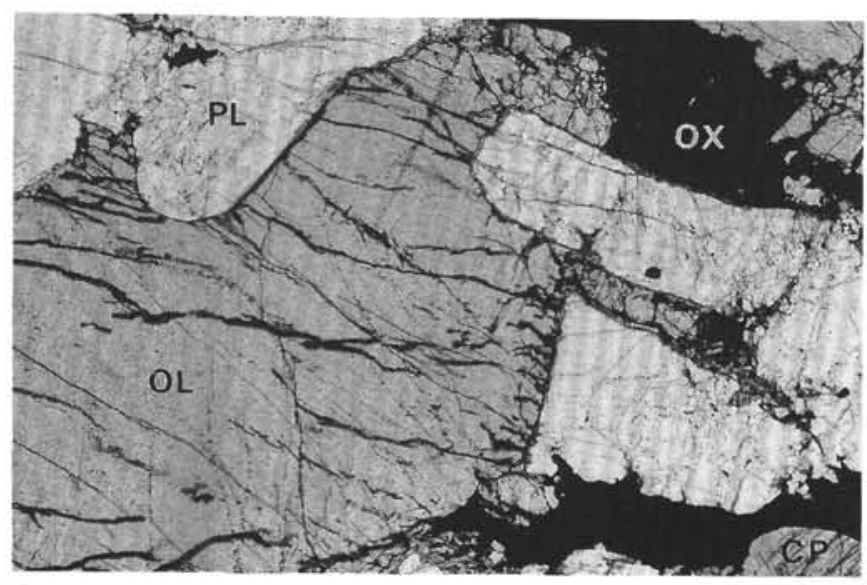

5

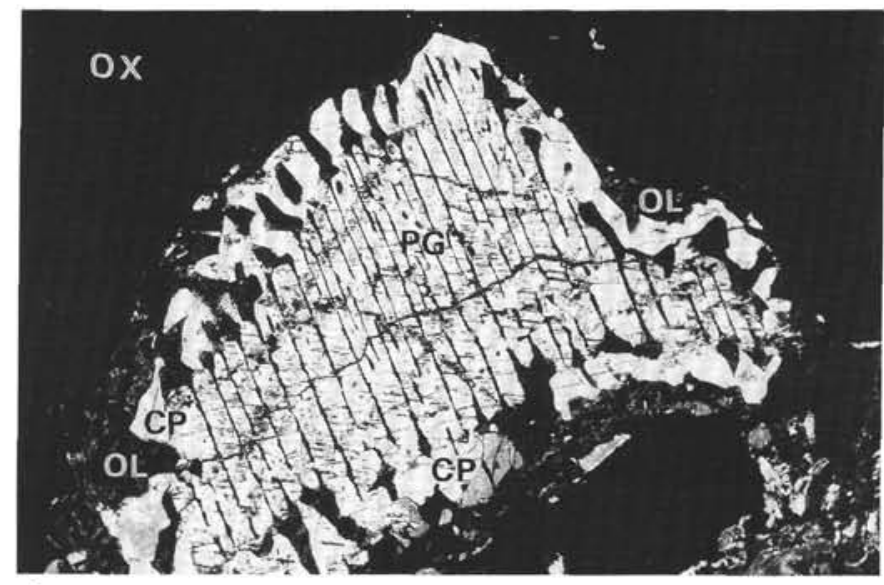

4

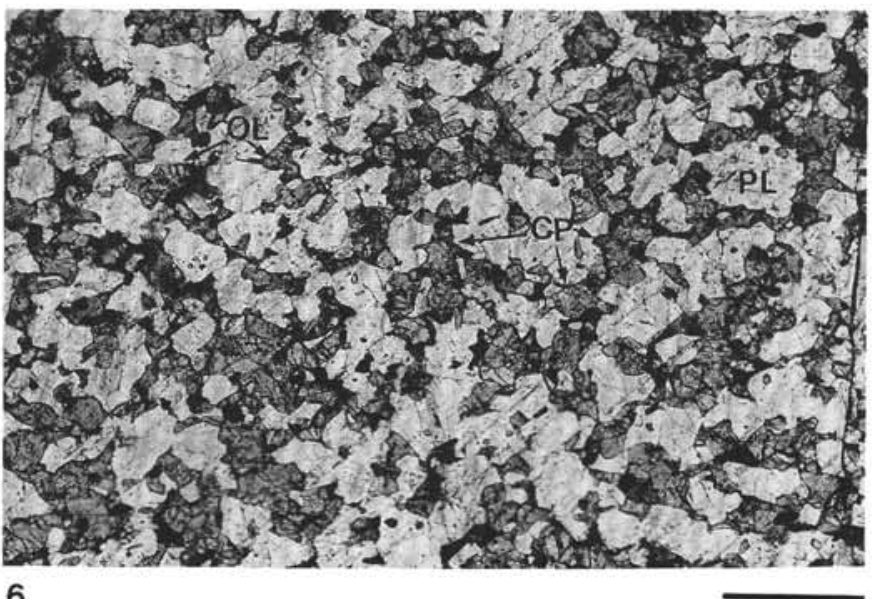

6

Plate 2. Thin section photomicrographs of Fe-Ti oxide gabbros. Scale bar is $1 \mathrm{~mm}$ long except for 4 , for which it is $0.5 \mathrm{~mm}$ long. 1. Sample 118-735B-73R-5, 72-78 cm. Interstitial olivine-bearing Fe-Ti oxide gabbro characterized by presence of minor interstitial olivine generally associated with Fe-Ti oxide. 2. Sample 118-735B-52R-1, 91-100 cm. Thin olivine mantle present between Fe-Ti oxides and plagioclase in interstitial olivine-bearing Fe-Ti oxide gabbro. 3. Sample 118-735B-50R-3, 62-67 cm. Corroded and inverted pigeonite in the core of clinopyroxene in interstitial olivine-bearing Fe-Ti oxide gabbro. 4. Sample 118-735B-49R-2, 94-100 cm. Inverted pigeonite surrounded by an intergrowth of clinopyroxene and olivine, which are further surrounded by Fe-Ti oxide minerals. 5. Sample 118-735B-54R-3, 125-127 cm. Olivine Fe-Ti oxide gabbro containing abundant cumulus olivine. 6. Sample 118-735B-48R-2, 109-113 cm. Olivine Fe-Ti oxide microgabbro containing plagioclase, olivine, clinopyroxene, and Fe-Ti oxides. Abbreviations are the same as in Plate 1. 

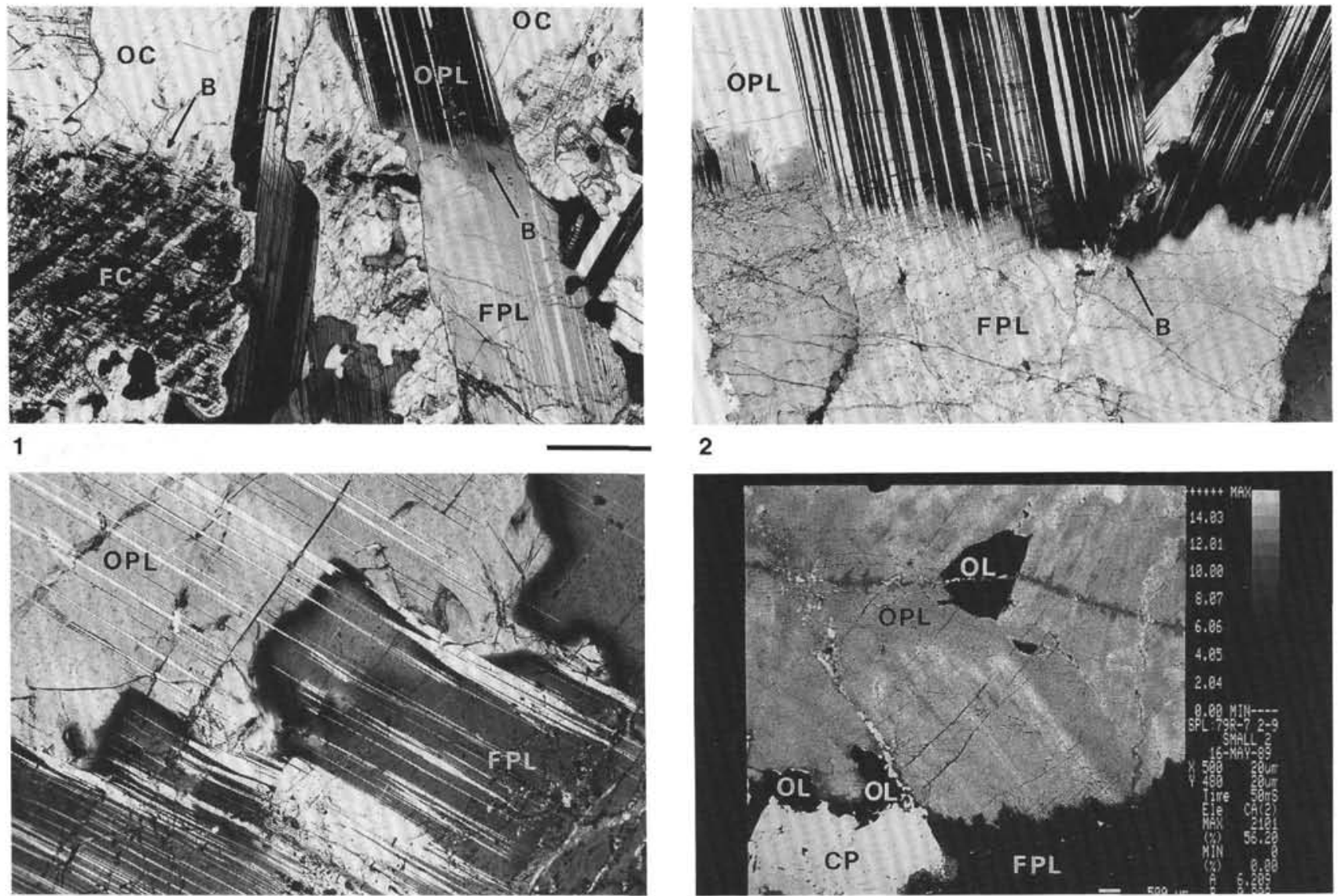

3

2

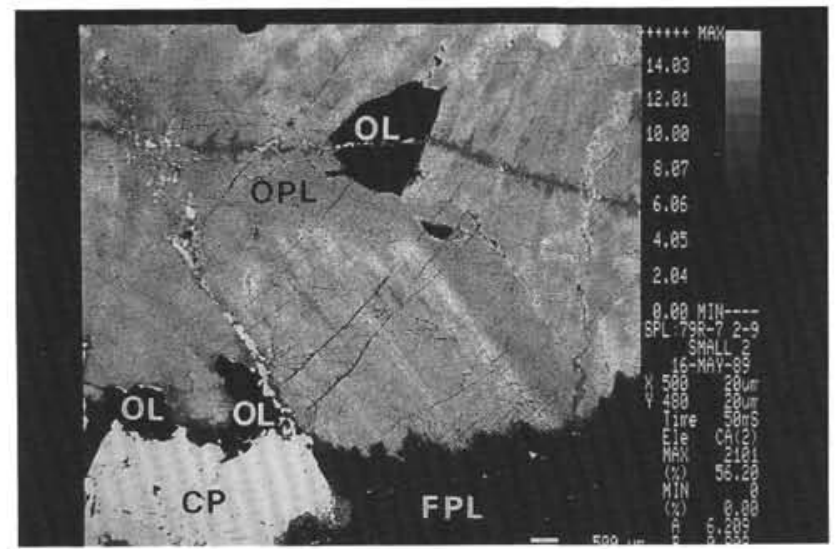

4

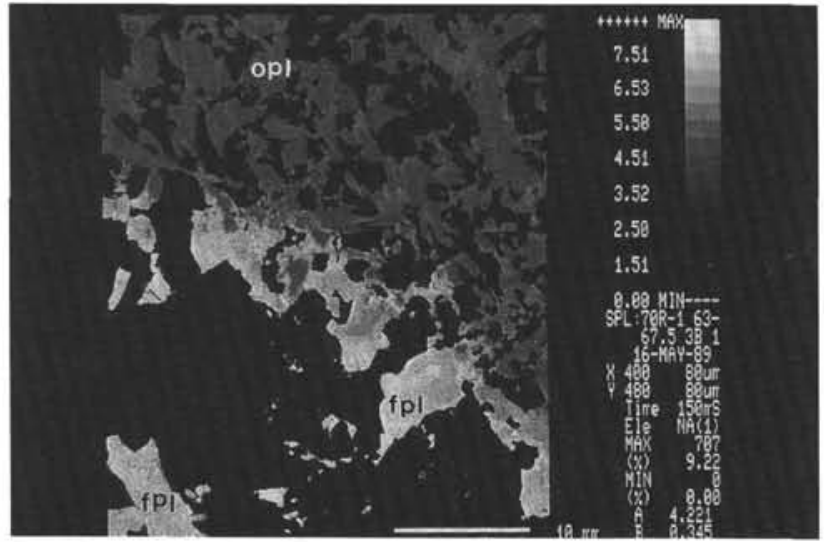

5

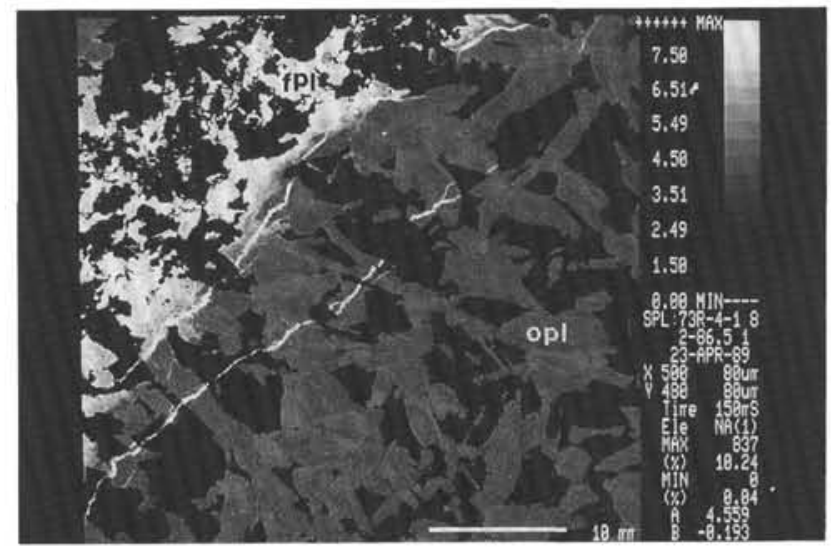

6

Plate 3. Thin section photomicrographs and element distribution map of contact zones between olivine and Fe-Ti oxide gabbros. Scale bar is $1 \mathrm{~mm}$ for Figs. 1. and 2., and $0.2 \mathrm{~mm}$ for Fig. 3. 1. Sample 118-735B-73R-5, 72-78 cm. Slightly diffuse contact between olivine gabbro (above) and $\mathrm{Fe}$-Ti oxide gabbro (below). Note that clinopyroxene in Fe-Ti oxide gabbro contains many exsolution lamellae of opaque minerals, whereas no lamellae is present in clinopyroxene of olivine gabbro. 2. Sample, 118-735B-79R-7, 2-9 cm. Sharp contact between olivine gabbro (above) and Fe-Ti oxide gabbro (below). Polysynthetic twins are continuous in plagioclase of both gabbros, though extinction position is different because of the difference in An content. This photomicrograph indicates that sodic plagioclase of Fe-Ti oxide gabbro overgrew the fractured calcic plagioclase of olivine gabbro. 3. Enlarged view of the left side of Fig. 2., showing that chemical composition of plagioclase changes within hundred microns from the olivine gabbro to the Fe-Ti oxide gabbro. Note the continuous twin boundaries. 4. Calcium distribution map at the contact of olivine gabbro and $\mathrm{Fe}$ - $\mathrm{Ti}$ oxide gabbro (the same sample as in Fig. 2). Black area is mostly plagioclase with an An content of 30 . Note that the zoning pattern is sharply cut by plagioclase in Fe-Ti oxide gabbro. 5. Sample 118-735B-70R-1, 63-68 cm. Sodium distribution map of the boundary between olivine gabbro and Fe-Ti oxide gabbro. The zoning in plagioclase indicates that the boundary is more irregular and diffused than those in Figs. 1 and 2 . 6. Sample 118-735B-73R-4, 82-87 cm. Fe-Ti oxide dike (1.5 cm thick) in olivine gabbro. The boundary is more diffused than the case in Figs. 1 and 2, but is less diffused than that in Fig. 5. White veins are late stage albite. OC: clinopyroxene in olivine gabbro, FC: clinopyroxene in Fe-Ti oxide gabbro, OPL: plagioclase in olivine gabbro, FPL: plagioclase in Fe-Ti oxide gabbro, B: boundary of olivine and Fe-Ti oxide gabbros. Other abbreviations are the same as in Plate 1. Numbers besides the brightness bar in the element distribution maps are $\mathrm{CaO}$ wt $\%$ for Fig. 4 or $\mathrm{Na}_{2} \mathrm{O}$ wt $\%$ for Figs. 5 and 6. 